Prepared in cooperation with the MINNESOTA GEOLOGICAL SURVEY AND BUREAU OF RECLAMATION, U.S. DEPARTMENT OF THE INTERIOR

\title{
Ground-Water Availability from Surficial Aquifers in the Red River of the North Basin, Minnesota
}

Scientific Investigations Report 2005-5204 


\title{
Ground-Water Availability from Surficial Aquifers in the Red River of the North Basin, Minnesota
}

\author{
By Thomas H.C. Reppe
}

Prepared in cooperation with the Minnesota Geological Survey and Bureau of Reclamation, U.S. Department of the Interior

Scientific Investigations Report 2005-5204 


\title{
U.S. Department of the Interior Gale A. Norton, Secretary
}

\author{
U.S. Geological Survey \\ P. Patrick Leahy, Acting Director
}

\section{U.S. Geological Survey, Reston, Virginia: 2005}

\author{
For sale by U.S. Geological Survey, Information Services \\ Box 25286, Denver Federal Center \\ Denver, CO 80225 \\ For more information about the USGS and its products: \\ Telephone: 1-888-ASK-USGS \\ World Wide Web: http://www.usgs.gov/
}

Any use of trade, product, or firm names in this publication is for descriptive purposes only and does not imply endorsement by the U.S. Government.

Although this report is in the public domain, permission must be secured from the individual copyright owners to reproduce any copyrighted materials contained within this report.

Suggested citation:

Reppe, T.H.C., 2005, Ground-water availability from surficial aquifers in the Red River of the North Basin, Minnesota: U.S. Geological Survey Scientific Investigations Report 2005-5204, 54 p. 


\section{Contents}

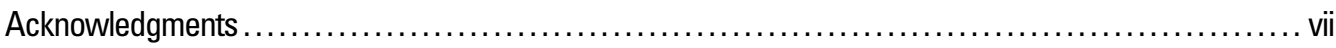

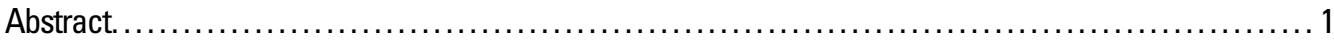

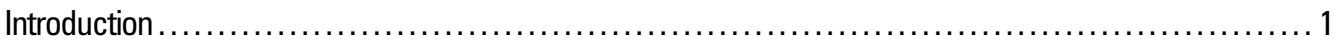

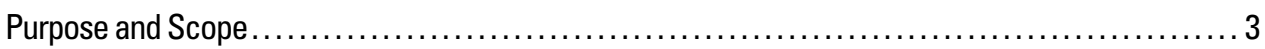

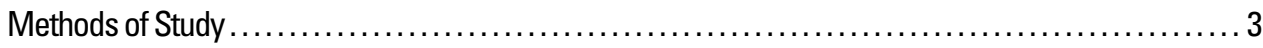

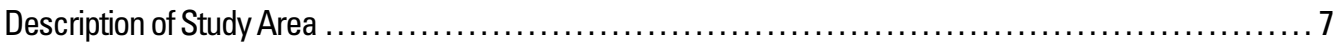

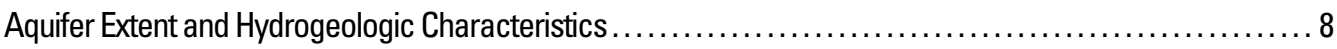

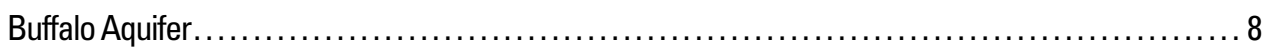

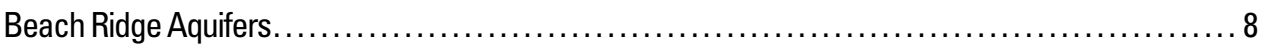

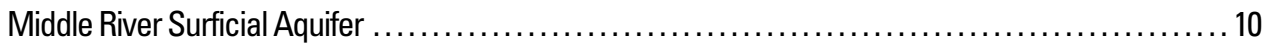

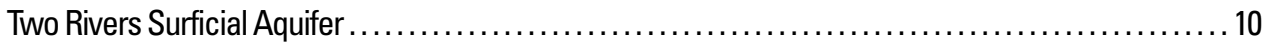

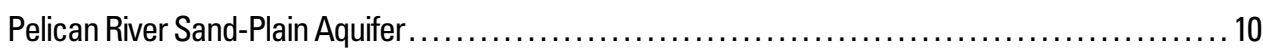

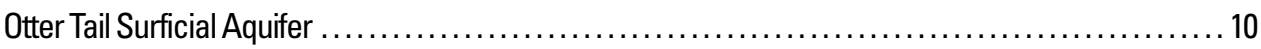

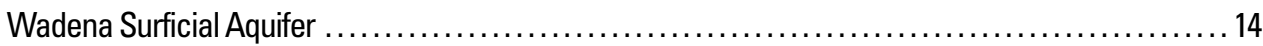

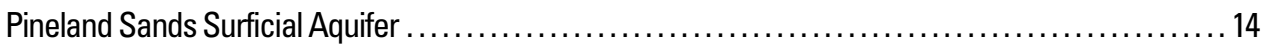

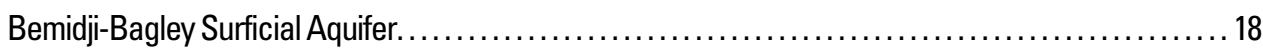

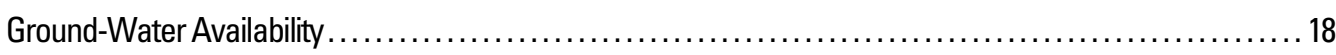

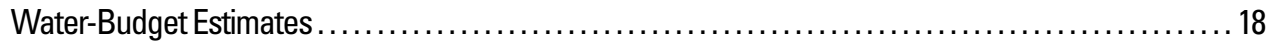

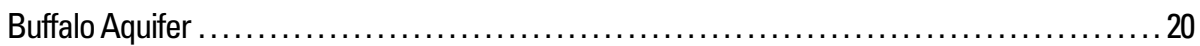

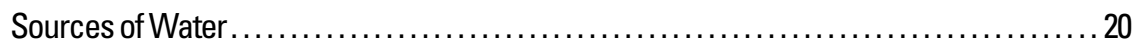

Losses of Water................................................... 20

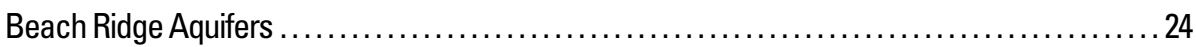

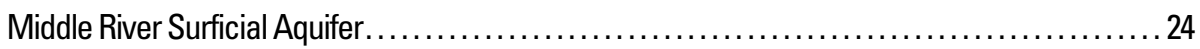

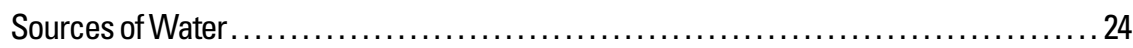

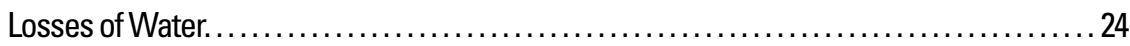

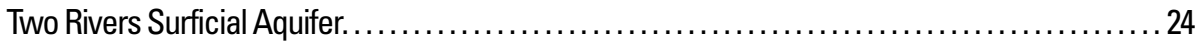

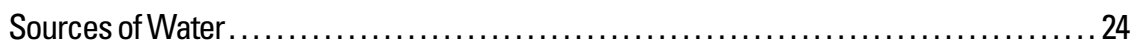

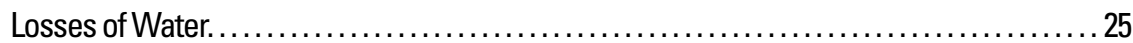

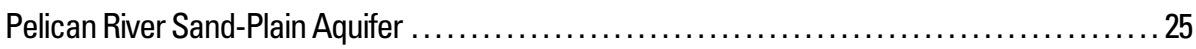

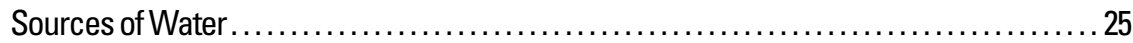

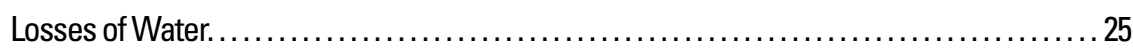

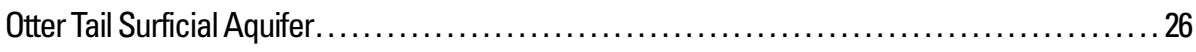

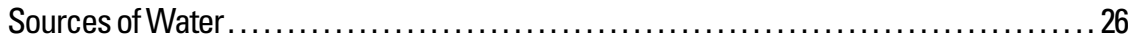

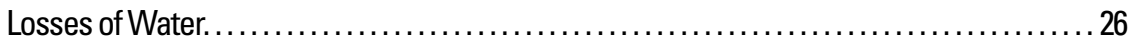

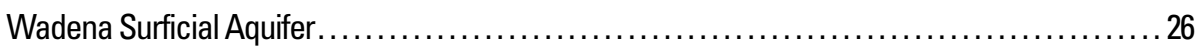

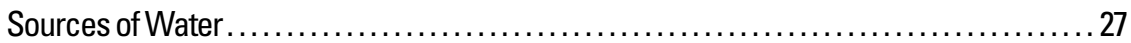

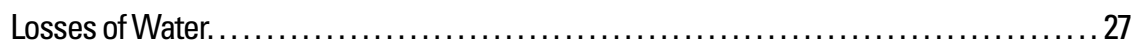

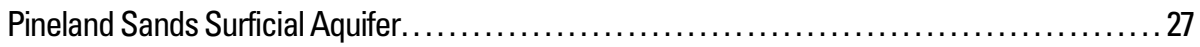

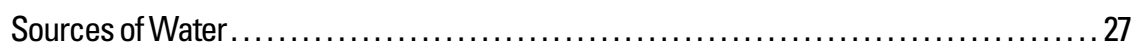

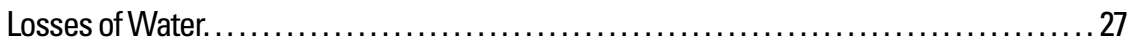

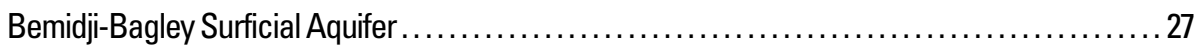

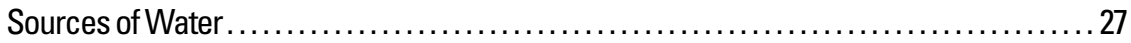




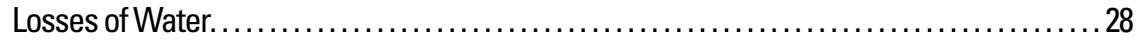

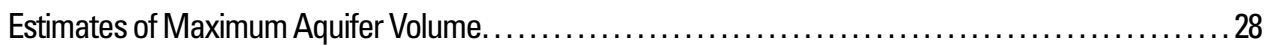

Theoretical Well Yields and Ground-Water Pumping Tests and Simulations .................... 28

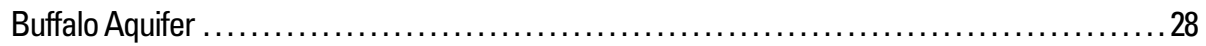

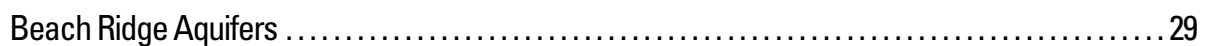

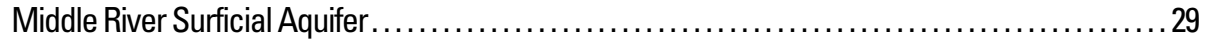

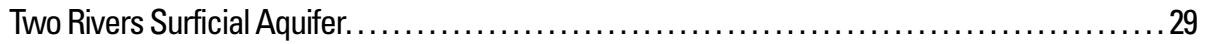

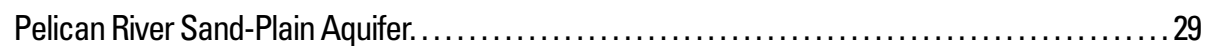

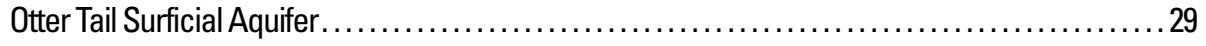

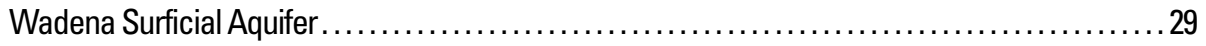

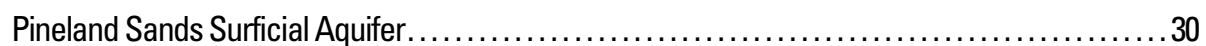

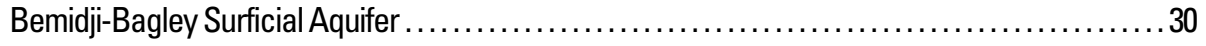

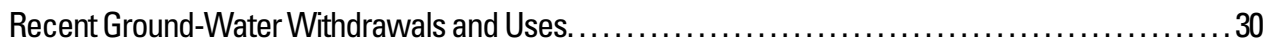

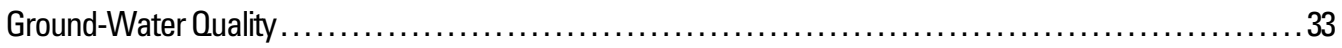

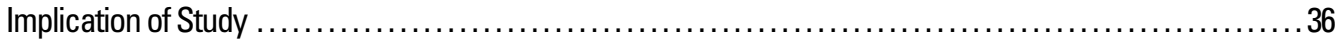

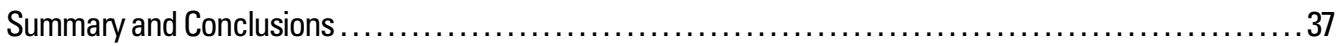

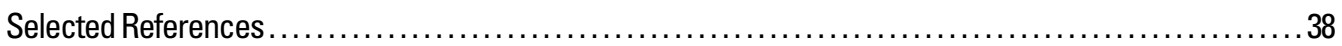

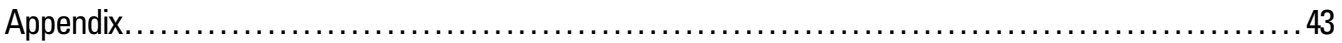

\section{Figures}

1-10. Maps showing:

1. Location of Red River of the North Basin, major physiographic areas, and beach ridge

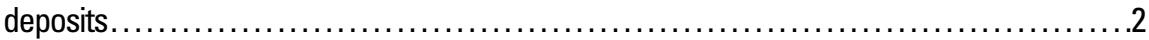

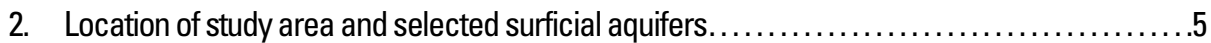

3. Generalized extent, saturated thickness, altitude of regional water table, and generalized

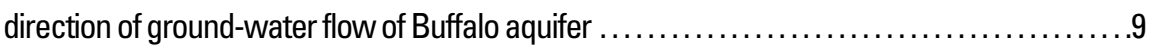

4. Generalized extent, altitude of regional water table, and generalized direction of ground-water flow of Middle River surficial aquifer....

5. Generalized extent, altitude of regional water table, and generalized direction of ground-water flow of Two Rivers surficial aquifer.

6. Generalized extent, saturated thickness, altitude of regional water table, and generalized direction of ground-water flow of Pelican River sand-plain aquifer..

7. Generalized extent, saturated thickness, altitude of regional water table, and generalized direction of ground-water flow of Otter Tail surficial aquifer.

8. Generalized extent, saturated thickness, altitude of regional water table, and generalized direction of ground-water flow of Wadena surficial aquifer

9. Generalized extent, saturated thickness, altitude of water table, and generalized direction of ground-water flow of Pineland Sands surficial aquifer.

10. Generalized extent, saturated thickness, altitude of regional water table, and generalized direction of ground-water flow of Bemidji-Bagley surficial aquifer................... 19

11. Schematic diagram of a surficial aquifer system showing potential sources and losses of water . 20

12. Concentrations of dissolved solids, sulfate, nitrate (as nitrogen), and iron in water from selected surficial aquifers and physiographic areas. 


\section{Tables}

1. Aquifer characteristics of surficial aquifers in Red River of the North Basin, Minnesota............4

2. Water budgets for selected surficial aquifers in Red River of the North Basin, Minnesota......... 21

3. Nonsteady-state water budget for Buffalo aquifer in Red River of the North Basin, Minnesota,

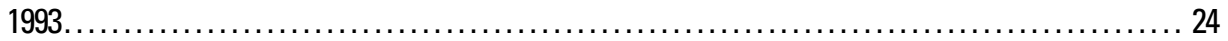

4. Nonsteady-state water budget for Middle River surficial aquifer in Red River of the North Basin,

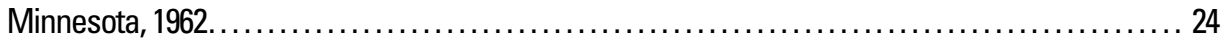

5. Nonsteady-state water budget for Two Rivers surficial aquifer in Red River of the North Basin,

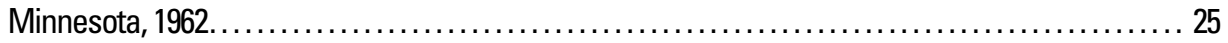

6. Steady-state simulated water budget from "Detroit Lakes model" for Pelican River sand-plain aquifer in Red River of the North Basin, Minnesota ................................. 25

7. Steady-state simulated water budget from "Scrambler model" for Pelican River sand-plain aquifer in Red River of the North Basin, Minnesota......................................... 25

8. Nonsteady-state water budget for Otter Tail surficial aquifer in Red River of the North Basin,

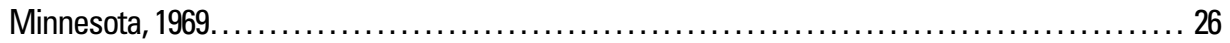

9. Steady-state simulated water budget for Wadena surficial aquifer in Red River of the North Basin,

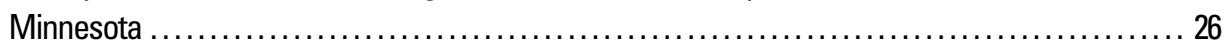

10. Steady-state simulated water budget for Pineland Sands surficial aquifer in Red River of the

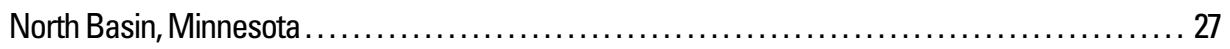

11. Nonsteady-state water budget for Bemidji-Bagley surficial aquifer in Red River of the North Basin,

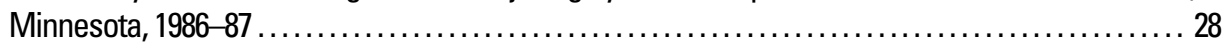

12. Ground-water withdrawals from selected surficial aquifers in Red River of the North Basin, Minne-

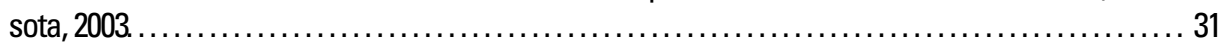

13. Concentrations of selected water-quality constituents in surficial aquifers in Red River of the

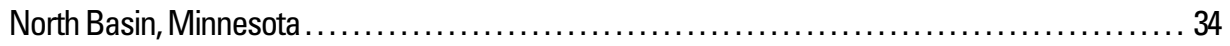

A1. Specific references cited for selected surficial aquifers in Red River of the North Basin,

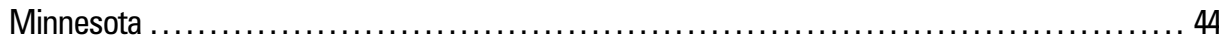

A2. General references cited for Red River of the North Basin, Minnesota .................... 47

A3. Comprehensive list of estimated water budgets for selected surficial aquifers in Red River of the

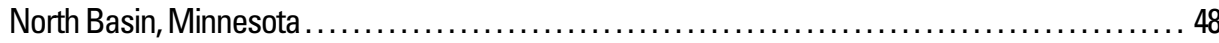




\section{Conversion Factors, Abbreviations, and Datum}

\begin{tabular}{lcl}
\hline Multiply & By & To obtain \\
\hline & Length & \\
inch (in.) & 25.4 & millimeter $(\mathrm{mm})$ \\
foot (ft) & 0.3048 & meter $(\mathrm{m})$ \\
mile (mi) & 1.609 & kilometer $(\mathrm{km})$ \\
& Area & \\
acre & 4,047 & square meter $\left(\mathrm{m}^{2}\right)$ \\
square foot $\left(\mathrm{ft}^{2}\right)$ & 0.09290 & square meter $\left(\mathrm{m}^{2}\right)$ \\
square mile $\left(\mathrm{mi}^{2}\right)$ & 2.590 & square $\mathrm{kilometer}\left(\mathrm{km}^{2}\right)$ \\
& Volume & \\
gallon (gal) & 0.003785 & cubic meter $\left(\mathrm{m}^{3}\right)$ \\
million gallons $(\mathrm{Mgal})$ & 3,785 & cubic meter $\left(\mathrm{m}^{3}\right)$ \\
billion gallons $(\mathrm{bgal})$ & $3,785,000$ & cubic meter $\left(\mathrm{m}^{3}\right)$ \\
& Flow rate & \\
inch per year (in/yr) & 25.4 & millimeter per year $\left(\mathrm{mm}^{3} / \mathrm{yr}\right)$ \\
foot per mile $(\mathrm{ft} / \mathrm{mi})$ & 0.1894 & meter per kilometer $(\mathrm{m} / \mathrm{km})$ \\
cubic foot per second $\left(\mathrm{ft}{ }^{3} / \mathrm{s}\right)$ & 28.32 & liter per second $(\mathrm{L} / \mathrm{s})$ \\
foot squared per day $\left(\mathrm{ft}^{2} / \mathrm{d}\right)$ & 0.09290 & meter squared per day $\left(\mathrm{m}^{2} / \mathrm{d}\right)$ \\
gallon per minute $(\mathrm{gal} / \mathrm{min})$ & 0.06309 & liter per second $(\mathrm{L} / \mathrm{s})$ \\
million gallons per year $(\mathrm{Mgal} / \mathrm{yr})$ & 3,785 & cubic meter per year $\left(\mathrm{m}^{3} / \mathrm{yr}\right)$ \\
billion gallons per year $(\mathrm{bgal} / \mathrm{yr})$ & $3,785,000$ & cubic meter per year $\left(\mathrm{m}^{3} / \mathrm{yr}\right)$ \\
\hline
\end{tabular}

Horizontal coordinate information is referenced to the North American Datum of 1983 (NAD 83).

Vertical coordinate information is referenced to the North American Vertical Datum of 1988 (NAVD 88)."

Specific conductance is given in microsiemens per centimeter at 25 degrees Celsius $(\mu \mathrm{S} / \mathrm{cm}$ at $\left.25^{\circ} \mathrm{C}\right)$.

Chemical concentrations of substances in water are given in milligrams per liter (mg/L). Milligrams per liter is a unit expressing the concentration of chemical constituents in solution as weight (milligrams) of solute per unit volume (liter) of water. For concentrations less than $7,000 \mathrm{mg} / \mathrm{L}$, the numerical value is the same as for concentrations in parts per million. 


\section{Acknowledgments}

\section{Data Compilation Assistance}

Allan D. Arntson, Hydrologist, U.S. Geological Survey, Minnesota

D. Luke Thompson, Student, U.S. Geological Survey, Minnesota

\section{Technical Reviewers}

Timothy K. Cowdery, Hydrologist, U.S. Geological Survey, Minnesota

Charles P. Dunning, Hydrologist, U.S. Geological Survey, Minnesota

David Ripley, North Dakota State Water Commission

James R. Stark, Supervisory Hydrologist, U.S. Geological Survey, Minnesota

\section{Geographic Information System Assistance}

Jacqueline D. Hamilton, Contractor, U.S. Geological Survey, Minnesota

Chris A. Sanocki, Geographer, U.S. Geological Survey, Minnesota

\section{Editorial and Graphics}

Robert Borgstede, Illustrator, U.S. Geological Survey, Minnesota

Lanna J. Combs, Technical Editor, U.S. Geological Survey, Kansas Water Science Center 


\title{
Ground-Water Availability from Surficial Aquifers in the Red River of the North Basin, Minnesota
}

\author{
By Thomas H.C. Reppe
}

Abstract

Population growth and commercial and industrial development in the Red River of the North Basin in Minnesota, North Dakota, and South Dakota have prompted the Bureau of Reclamation, U.S. Department of the Interior, to evaluate sources of water to sustain this growth. Nine surficial-glacial (surficial) aquifers (Buffalo, Middle River, Two Rivers, Beach Ridges, Pelican River, Otter Tail, Wadena, Pineland Sands, and Bemidji-Bagley) within the Minnesota part of the basin were identified and evaluated for their ground-water resources. Information was compiled and summarized from published studies to evaluate the availability of ground water. Published information reviewed for each of the aquifers included location and extent, physical characteristics, hydraulic properties, ground-water and surface-water interactions, estimates of water budgets (sources of recharge and discharge) and aquifer storage, theoretical well yields and actual ground-water pumping data, recent (2003) ground-water use data, and baseline groundwater-quality data.

Water-budget estimates for the aquifers were compiled from steady-state aquifer simulations, precipitation data and hydrograph analysis, and recharge and discharge information. Major sources of recharge to the aquifers are areal recharge, flow from surface water, and flow across aquifer boundaries from adjacent geologic units. Losses of water from the aquifers include evapotranspiration, flow to surface water, flow across aquifer boundaries, and withdrawals by pumping wells. The Bemidji-Bagley, Otter Tail, Pineland Sands, and Wadena surficial aquifers have the highest rates of water inflow and outflow of the nine aquifers in the study area, and the Middle River surficial aquifer has the lowest rates of total water inflow and outflow.

Maximum storage volumes of five of the surficial aquifers were calculated using areal extent and published saturated thickness and porosity data. Storage estimates from published studies were included for three of the surficial aquifers.

Maximum theoretical well yields for the aquifers generally occur in areas with more abundant, well-sorted, coarse-grained sediment. In 2003, 28 billion gallons of ground water were withdrawn from the aquifers, not including water used for private supply. In 2003, the largest volume of ground water was withdrawn from the Otter Tail surficial aquifer, and the smallest volume was withdrawn from the the Middle River surficial aquifer. Agricultural irrigation and public supply totaled
95 percent of the volume of ground water withdrawn from the aquifers in 2003.

Ground-water-quality data indicate that the Buffalo aquifer contained the largest specific conductance and concentrations of dissolved solids, calcium, magnesium, sodium, sulfate, and iron. Ground water from the Bemidji-Bagley, Otter Tail, Pineland Sands, and Wadena surficial aquifers contained the largest concentrations of nitrate (as nitrogen). In general, the nine aquifers are hydraulically connected to local surface water. Simulations of ground-water development for some of the aquifers describe correlations between increased ground-water withdrawals and declining lake levels and streamflows, lower water-table altitudes, and variations in ground-water quality.

On the basis of data and methods presented to evaluate ground-water availability, the Otter Tail and Pineland Sands surficial aquifers and Pelican River sand-plain aquifer have the greatest potential for additional development of ground-water resources in the study area.

\section{Introduction}

Increases in population, commerce, and industry in the Red River of the North Basin (hereinafter, the basin) in Minnesota, North Dakota, and South Dakota (fig. 1) during recent decades has led the Bureau of Reclamation (Reclamation), U.S. Department of the Interior, to evaluate sources of water to sustain the growth. One source of water supply under consideration by Reclamation is a diversion of surface water from the Missouri River Basin to the Fargo-Moorhead area through the Garrison Diversion-Sheyenne River project (U.S. Department of the Interior, Bureau of Reclamation, 2005). Prior to the allocation of resources to the Garrison Diversion project, an assessment of water supplies, including ground-water resources, was needed to fully describe and develop the project.

Water-supply alternatives in the area include additional surface-water and ground-water resources in and adjacent to the basin. In North Dakota, much of the work needed to complete an evaluation of ground water from surficial aquifers has been completed by State and Federal agencies. However, similar evaluations of surficial aquifers and ground-water resources in the Minnesota part of the basin have not been completed.

The U.S. Geological Survey (USGS), in cooperation with the Minnesota Geological Survey (MGS) and Reclamation, 


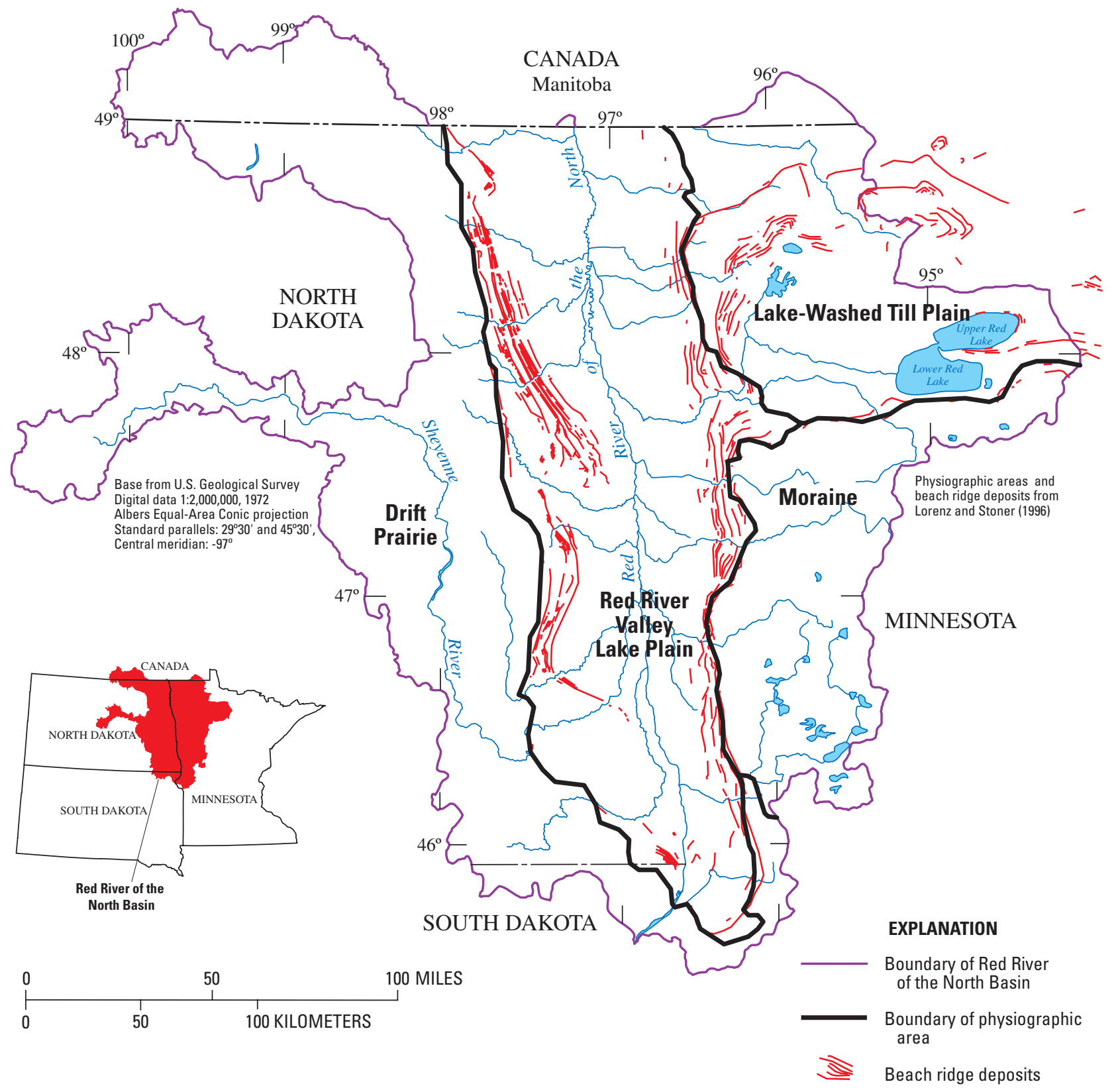

Figure 1. Location of Red River of the North Basin, major physiographic areas, and beach ridge deposits.

compiled data from nine selected surficial-glacial (surficial) aquifers located throughout and (or) adjacent to the Minnesota part of the basin. The selected aquifers are the Buffalo aquifer, Beach Ridge aquifers, Middle River surficial aquifer, Two Rivers surficial aquifer, Pelican River sand-plain aquifer, Otter Tail surficial aquifer, Wadena surficial aquifer, Pineland Sands surficial aquifer, and Bemidji-Bagley surficial aquifer. The information was compiled to assess the availability of groundwater resources in the Red River of the North Basin for the Red River Valley Water-Supply Project of Reclamation and the Garrison Diversion Conservancy District.

The relation between net ground-water recharge (and natural discharge) and aquifer storage, safe yield, and sustainability is important in evaluating and understanding the availability of ground water. Withdrawals of ground water from pumping wells change natural flow conditions in aquifers. The source of water withdrawn from wells comes from a combination of increased ground-water recharge, increased inflow from other sources (such as rivers and streams), decreased natural discharge, or a reduction of ground-water storage. Responses to pumping are temporary and occur as the aquifer readjusts to pumping stress and the changes in storage, recharge, and discharge. As an aquifer establishes equilibrium, changes in storage diminish to zero (at a new, reduced level), and total groundwater inflows balance outflows. Thus, the long-term source of water to pumping wells comes from variations in the amount of 
water entering or leaving the aquifer system. The time required for an aquifer to establish a new equilibrium is a function of the characteristics of the aquifer and the placement and pumping rates of wells.

A common misperception is that ground-water pumping is "safe" when mean pumping rates do not exceed net mean recharge. Also, natural net ground-water recharge is sometimes erroneously assumed to be equivalent to an aquifer's sustainable yield (Bredehoeft, 1997). Sometimes, an additional misinterpretation is that pumping rates less than recharge rates will not cause water-level declines and decreases in ground-water storage. Any amount of ground-water pumping will affect the storage and (or) recharge to and natural discharge from an aquifer to some extent. The negative effects of pumping are the most important issues that need to be considered in defining safe yield and sustainability. However, determining these effects and their relation to safe ground-water yield and sustainability were beyond the scope of this study.

Ground-water sustainability is a policy issue as well as a technical subject. Many factors, including hydrogeologic, hydraulic, environmental, economic, and social issues, need to be balanced when determining ground-water sustainability. The Minnesota Department of Natural Resources (MDNR) considers sustainable use of ground water as the use of water that provides for the current and future needs of society without unacceptable social, economic, or environmental consequences (Minnesota Department of Natural Resources, 2005).

Estimates of ground-water recharge, discharge, and aquifer storage cannot be used alone to determine the amount of ground water that can be withdrawn on a sustained basis. The amount of water available for use depends on how the changes in flow resulting from pumping affect the aquifer and the surrounding environment, as well as the acceptable tradeoffs between ground-water use and these changes (Alley and others, 1999; Alley and Leake, 2004).

\section{Purpose and Scope}

This report describes some of the hydrologic characteristics of the surficial aquifers in the Minnesota part of the Red River of the North Basin by using data compiled in a consistent manner from readily available, published information. Compilation of these data was needed as a first step in evaluating the sustainable use of ground water from the aquifers located in the study area. The report summarizes and describes existing information published between 1960 and 2002 about: (1) the physical and hydrogeologic characteristics of nine selected surficial aquifers including location, areal extent and thickness, hydraulic properties, ground-water flow direction, and ground-water surface-water interactions; (2) the availability of ground water in the surficial aquifers and existing information about the effects of pumping on water levels; and (3) baseline water quality of samples collected from the aquifers.

\section{Methods of Study}

The availability of ground water in the surficial aquifers in the Minnesota part of the basin was evaluated by compiling and summarizing the physical characteristics, hydraulic properties, estimates of water budgets and aquifer storage, theoretical well yields and ground-water pumping data, ground-water use estimates and types, and ground-water-quality data. Aquifer characteristics and properties included estimates of horizontal and vertical extent, saturated thickness, transmissivity, hydraulic conductivity, storativity, porosity, specific yield, and theoretical well yields (table 1). The data were compiled from studies previously published by MDNR, USGS, and other sources.

Throughout this report, the nine selected surficial aquifers of the Red River of the North Basin are presented and discussed in order from those nearest the Red River (west), to the aquifers located farthest from the river (east) (figs. 1 and 2). The purpose of presenting the aquifers in the selected order is threefold: (1) the surficial aquifers are generally located distinctly within one of the three physiographic areas of the basin (Red River Valley Lake Plain, Lake-Washed Till Plain, and Moraine) (fig. 1), (2) the availability of ground water from each aquifer also is presented and evaluated with respect to distance from the major areas of increasing water-supply need (the Fargo-Moorhead and Grand Forks areas), and (3) trends in ground-waterquality data demonstrate that concentrations of selected constituents are substantially different in water samples collected from surficial aquifers located nearest the Red River (westernmost aquifers) than those located on the eastern side of the basin.

Although the study areas and aquifer extents defined by previous studies were similar, they were not always identical or contiguous. As a result, in some cases, the compiled maps showing aquifer extent, water-table surface, and saturated thickness overlap and (or) contain areas of missing data. Although the compilation of data from numerous studies produced discrepancies in the maps, the most recent and comprehensive information is presented as published without modifications and (or) interpretations. For example, some of the aquifers' water-table contours contain gaps and overlaps produced by compiling two or more sets of contour lines.

The values of maximum and mean slopes of the water tables in the selected aquifers were estimated by measuring the vertical difference between two water-table contour lines along a ground-water flow path (in feet) and dividing by the total length of the flow path line (in miles). Maximum water-table 
Table 1. Aquifer characteristics of surficial aquifers in Red River of the North Basin, Minnesota.

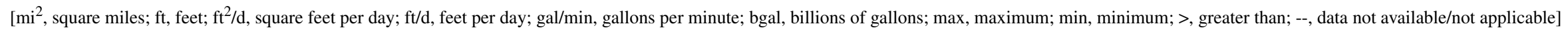

\begin{tabular}{|c|c|c|c|c|c|c|c|c|c|c|c|c|c|c|c|c|c|}
\hline \multirow[b]{2}{*}{$\begin{array}{l}\text { Aquifer name } \\
\text { (reference) }\end{array}$} & \multirow[b]{2}{*}{$\begin{array}{l}\text { Areal } \\
\text { extent } \\
\left(\mathrm{mi}^{2}\right)\end{array}$} & \multirow[b]{2}{*}{$\begin{array}{l}\text { Aquifer } \\
\text { thick- } \\
\text { ness (ft) } \\
\max \end{array}$} & \multicolumn{2}{|c|}{$\begin{array}{l}\text { Saturated } \\
\text { thickness (ft) }\end{array}$} & \multicolumn{3}{|c|}{ Transmissivity $\left(\mathrm{ft}^{2} / \mathrm{d}\right)$} & \multicolumn{2}{|c|}{$\begin{array}{c}\text { Hydraulic } \\
\text { conductivity (ft/d) }\end{array}$} & \multirow[b]{2}{*}{$\begin{array}{l}\text { Stora- } \\
\text { tivity } \\
\text { (dimen- } \\
\text { sionless) }\end{array}$} & \multirow[b]{2}{*}{$\begin{array}{l}\text { Porosity } \\
\text { (dimen- } \\
\text { sionless) }\end{array}$} & \multirow[b]{2}{*}{$\begin{array}{l}\text { Specific } \\
\text { yield } \\
\text { (dimen- } \\
\text { sionless) }\end{array}$} & \multicolumn{3}{|c|}{$\begin{array}{l}\text { Theoretical well yield } \\
\text { (gal/min) }\end{array}$} & \multirow{2}{*}{$\begin{array}{c}\text { Maxi- } \\
\text { mum } \\
\text { volume of } \\
\text { water } \\
\text { capable } \\
\text { of being } \\
\text { stored }^{1} \\
\text { (bgal) }\end{array}$} & \multirow{2}{*}{$\begin{array}{c}\text { Per- } \\
\text { centage } \\
\text { of total } \\
\text { maxi- } \\
\text { mum } \\
\text { volume } \\
\text { stored in } \\
\text { eight } \\
\text { surficial } \\
\text { aquifers }\end{array}$} \\
\hline & & & $\max$ & mean & $\max$ & $\min$ & mean & $\max$ & $\min$ & & & & $\max$ & $\min$ & mean & & \\
\hline $\begin{array}{l}\text { Buffalo aquifer } \\
\text { (Wolf, 1981; Schoenberg, 1998) }\end{array}$ & 66 & 220 & 200 & 90 & 70,000 & 2,500 & -- & 500 & 20 & $\begin{array}{l}3 \mathrm{E}-05- \\
3.2 \mathrm{E}-02\end{array}$ & 0.30 & 0.20 & 10,000 & 200 & -- & ${ }^{2} 270$ & 9.4 \\
\hline $\begin{array}{l}\text { Beach Ridge aquifers } \\
\text { (Stoner and others, 1993) }\end{array}$ & -- & $>150$ & $>150$ & -- & 2,400 & -- & -- & -- & -- & .17 & -- & -- & 500 & 10 & -- & -- & -- \\
\hline $\begin{array}{l}\text { Middle River surficial aquifer } \\
\text { (Maclay and others, 1965) }\end{array}$ & 22 & 60 & -- & -- & 1,069 & 134 & 267 & -- & -- & .10 & -- & -- & 50 & 5 & -- & ${ }^{3} 4.6$ & .2 \\
\hline $\begin{array}{l}\text { Two Rivers surficial aquifer } \\
\text { (Maclay and others, 1965, 1967) }\end{array}$ & 146 & 280 & $>150$ & -- & 13,370 & 670 & -- & -- & -- & $0.1-0.2$ & -- & -- & $>1,000$ & 50 & -- & ${ }^{4} 400$ & 13.9 \\
\hline $\begin{array}{l}\text { Pelican River sand-plain aqufier } \\
\text { (Anderson, 1980; Miller, 1982) }\end{array}$ & 195 & 140 & $>100$ & 60 & 12,500 & 100 & 5,000 & 210 & 130 & -- & .20 & $0.17-0.29$ & 1,200 & 40 & 600 & 300 & 10.4 \\
\hline $\begin{array}{l}\text { Otter Tail surficial aquifer } \\
\text { (Winter and others, 1969; Reeder, 1972) }\end{array}$ & 510 & 100 & $>100$ & 50 & 26,800 & 6,700 & 14,500 & 410 & 86 & $0.1-0.2$ & -- & .12 & 1,500 & 200 & -- & 500 & 17.4 \\
\hline $\begin{array}{l}\text { Wadena surficial aquifer } \\
\text { (Lindholm, 1970; Lindgren, 2002) }\end{array}$ & 397 & 70 & 70 & 36 & 16,080 & 2,010 & -- & 321 & 193 & $0.11-0.18$ & -- & .25 & $>900$ & $<100$ & 300 & 150 & 5.2 \\
\hline $\begin{array}{l}\text { Pineland Sands surficial aquifer } \\
\text { (Helgesen, 1977; Stark and others, 1994) }\end{array}$ & 996 & 135 & 130 & 40 & 36,800 & 8,700 & -- & 630 & 320 & $0.18-0.25$ & -- & .20 & 4,000 & $<100$ & 500 & 1,000 & 34.8 \\
\hline $\begin{array}{l}\text { Bemidji-Bagley surficial aquifer } \\
\text { (Stark and others, 1991) }\end{array}$ & 630 & $<100$ & $>80$ & -- & 8,900 & 70 & -- & 750 & 250 & .20 & -- & .20 & 300 & 10 & -- & 250 & 8.7 \\
\hline Maximum & -- & -- & 200 & 90 & 70,000 & 8,700 & 14,500 & 250 & 320 & .20 & .30 & .25 & 10,000 & 200 & 600 & 1,000 & -- \\
\hline Minimum & -- & -- & 70 & 36 & 1,069 & 70 & 267 & 210 & 20 & .10 & .20 & .12 & 50 & 5 & 300 & 4.6 & -- \\
\hline Mean & -- & -- & 133 & 55 & 20,880 & 2,611 & 6,589 & 470 & 167 & .16 & .25 & .19 & 2,507 & 74 & 467 & 359 & -- \\
\hline Median & -- & -- & 130 & 50 & 13,370 & 1,340 & 5,000 & 455 & 162 & .17 & .25 & .20 & 1,200 & 40 & 500 & 285 & -- \\
\hline Total & -- & -- & -- & -- & -- & -- & -- & -- & -- & -- & -- & -- & -- & -- & -- & 2,875 & -- \\
\hline
\end{tabular}

${ }^{1}$ Estimated from the aquifer's extent, saturated thickness, and porosity (except where noted). ${ }^{2}$ Estimated by Wolf (1981).

${ }^{3}$ Estimated by Maclay and others (1965). ${ }^{4}$ Prorated using data determined by Schiner (1963). 


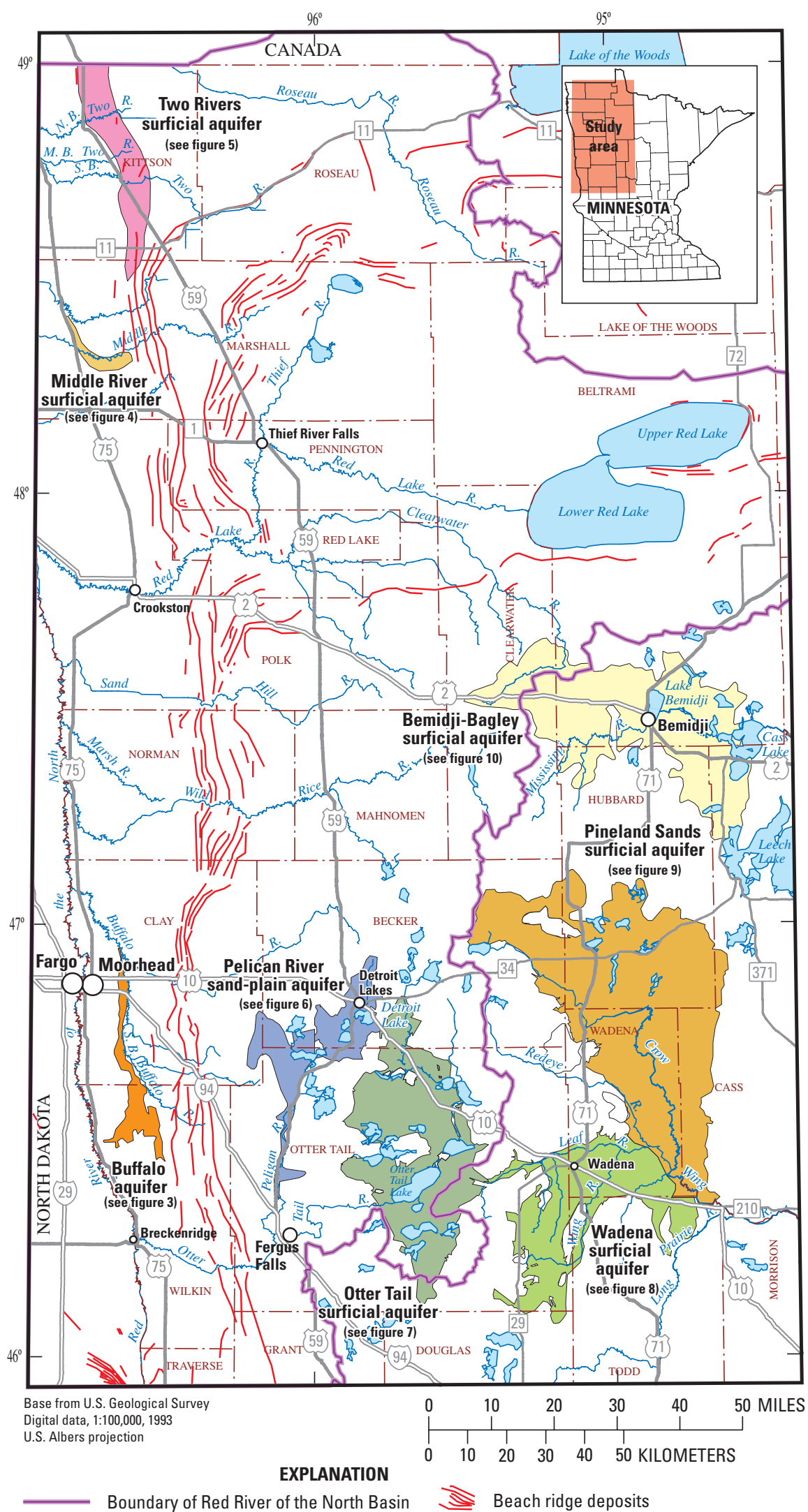

Figure 2. Location of study area and selected surficial aquifers. 


\section{Ground-Water Availability from Surficial Aquifers in the Red River of the North Basin, Minnesota}

slopes were estimated to provide an approximation of the steepest part of the water table, and mean slopes were measured to represent the general conditions of the water table during that measurement period. Mean slopes were determined by measuring the water-table slope in numerous places of the aquifer, including steep and gentle sloping areas. The number of measurements used to estimate mean slopes varied according to the size (aquifer extent) and characteristics (gradient and direction) of the water table, and in general ranged from 6 to 10 measurements per aquifer. The estimated maximum and mean watertable slopes are provided for relative comparison of the surficial aquifers in the study area. Because the maximum and mean slopes were estimated from water-table contours, the slopes represent the interpreted conditions of the aquifer at the time of measurement and, in many cases, represent regional water-table altitudes.

Saturated thickness data were compiled using published saturated thickness maps and data when available. Because the extent of saturated thickness data for some of the aquifers was not as large as the aquifers' extent, large parts of the aquifers do not have saturated thickness data. However, those parts of the aquifers are not necessarily unsaturated and may indicate only that data were not available. Exceptions are parts of the Bemidji-Bagley and Otter Tail surficial aquifers, which are known to be unsaturated and noted as such on the accompanying maps.

The volume of water in storage in each surficial aquifer was either compiled from specific aquifer studies (Buffalo aquifer and Middle River surficial aquifer), prorated for the most recently mapped aquifer extent on the basis of a published storage value calculated for a smaller subpart of the aquifer (Two Rivers surficial aquifer), or estimated from available aquifer areas, saturated thickness contour maps, and porosity data (Pelican River sand-plain aquifer, and the Otter Tail, Wadena, Pinelands Sands, and Bemidji-Bagley surficial aquifers).

The volume of water capable of being stored in the Two Rivers surficial aquifer was estimated from hydrologic properties determined by Schiner (1963) for a $24-\mathrm{mi}^{2}$ study area located in the Halma-Lake Bronson area of the aquifer. Assuming a mean storage coefficient of 0.10 and a mean saturated thickness of $130 \mathrm{ft}$, Schiner (1963) estimated that approximately 65 bgal of ground water could be stored within that part of the aquifer. Using the mean storage coefficient and saturated thickness data from Schiner (1963) and the most recently determined area of the aquifer $\left(146 \mathrm{mi}^{2}\right)$, the storage of the Two Rivers surficial aquifer was estimated. Although determining the storage of the aquifer using this method assumed that the mean storage coefficient and saturated thickness data were representative of the entire aquifer, it provided an estimate of groundwater storage on the basis of available hydrologic data.

Storage of some of the surficial aquifers was estimated from aquifer area, saturated thickness, and porosity data by (1) calculating saturated thickness areas (defined by contour lines) using geographic information system (GIS) methods; (2) assigning the median saturated thickness (for the interval defined by the contour lines) to each of the saturated thickness areas; (3) multiplying the calculated area from step 1 by the median saturated thickness from step 2, to determine a saturated volume for that area; (4) multiplying the saturated volumes from step 3 by either a known porosity, or an assumed value of 0.20 when porosity was unknown; and (5) summing all porosity-adjusted saturated volumes within the surficial aquifer. Aquifer storage volumes estimated using this method only represent that part of the surficial aquifer for which saturated thickness data were available. As a result, aquifers with an areal extent larger than the extent of the available saturated thickness data may contain greater estimates of stored ground water than those presented.

The method of approximating aquifer storage using aquifer area, saturated thickness, and porosity data is based on several assumptions. Some of the assumptions include homogeneous lithology (texture, sorting, and porosity) of the aquifer; median saturated thickness in the contour interval-derived areas (and a normal distribution of saturated thickness across each area); saturated thicknesses have not changed since the data were published; volumes represent storage in the part of the aquifer where saturated thickness data were available and do not include water potentially stored in areas where saturated thickness data were not available; and estimated volumes do not represent actual, available volumes of ground water that can be pumped from the surficial aquifers. Studies in North Dakota suggest that from 1 to 8 percent of stored ground water can be made available for pumping without substantial adverse effects to streamflow or lake levels (D. Ripley, North Dakota State Water Commission, written commun., 2005). Each of the surficial aquifers discussed in this report is unique, and the actual volume of ground water that can be pumped without adverse effects is likely to be a small percentage of the aquifer volumes estimated in this study.

Water-budget estimates for each of the surficial aquifers were compiled from data presented in individual studies. Three methods were utilized to estimate the water budgets and (or) the specific components, including (1) results from published, steady-state aquifer simulations; (2) published water-budget estimates that were based on precipitation data, hydrograph analysis, and infiltration capacities of soils; and (3) published recharge and discharge components. Generally, there are more data available regarding the sources of water inflow to the surficial aquifers than outflow (discharge) of water from the aquifers because inflow (recharge) is more easily measured or estimated. For most of the aquifer studies reviewed and summarized, only some of the water-budget components were known with precision.

In compiling and summarizing the water budgets for the aquifers, the major sources of water, determined on the basis of published methods, included (1) infiltration of precipitation to the water table (areal recharge); (2) flow from surface water (rivers, streams, lakes, and wetlands); and (3) flow from other geologic units across aquifer boundaries, including adjacent and confined aquifers, and confining units.

Major losses of water from the surficial aquifers typically occur through (1) evapotranspiration directly from the water 
table; (2) outflow to surface water; (3) flow across aquifer and confined boundaries; and (4) withdrawal of ground water by pumping wells. In general, the rate of ground-water evapotranspiration is greatest in those parts of the surficial aquifers where the water table is near land surface. Ground-water flow from, or to, the surficial aquifers to (from) surface water is dependent on (1) the thickness of the sediments in the surfacewater bed; (2) the hydraulic conductivity of the material; and (3) the hydraulic-head difference between the potentiometric surface of the aquifer and the elevation of the surface water.

For the purposes of comparison, the water-budget data were converted to millions of gallons per year ( $\mathrm{Mgal} / \mathrm{yr})$. As a result, estimates of mean net areal recharge from hydrograph analysis and infiltration capacity of soils may differ from values reported in previously published studies. Many of the waterbudget components for the aquifers were not previously determined or available. Additional information regarding sources of recharge to and discharge from the surficial aquifers may exist that are not presented in this report.

The theoretical well yields reported for the surficial aquifers are intended to represent general conditions and relative differences in the water-yielding capabilities of the aquifers, and are limited by various assumptions inherent to the methods of estimation. In general, maximum well yields of the aquifers, summarized from published studies, were determined by quantitative analysis of hydraulic properties using the Theis (1935) equation (Helgesen, 1977; Miller, 1982; Reeder, 1972; Wolf, 1981). Theoretical well yields in the Bemidji-Bagley and Otter Tail surficial aquifers were calculated by multiplying the specific capacity (pumping rate divided by drawdown) by the available drawdown (Stark and others, 1991; Reeder, 1972). Well yields for individual wells in the Pineland Sands surficial aquifer and Pelican River sand-plain aquifer were obtained by plotting saturated thickness (in feet) in relation to transmissivity (in feet squared per day) (Helgesen, 1977; Miller, 1982). Tranmissivity values were estimated using specific capacity data, obtained by pumping a well at a known constant rate and measuring ground-water levels in the well after a period of time (Miller, 1982).

Some of the assumptions in estimating theoretical well yields reported by Reeder (1972), Helgesen (1977), Wolf (1981), Miller (1982), and Stark and others (1991) included (1) that the aquifers were homogeneous, isotropic, and infinite in areal extent; (2) wells were screened through the entire thickness of the aquifers, were 100-percent efficient, and had a specified (study-dependent) diameter; (3) the effects of other pumping wells and hydrologic boundaries were negligible; (4) the storage coefficient was equal to 0.20 ; and (5) ground-water pumping was continuous for 30 days, with drawdown limited to two-thirds the initial saturated thickness of the aquifer (Reeder, 1972; Helgesen, 1977; Wolf, 1981; Miller, 1982) or until steady-state conditions occurred (Stark and others, 1991).

The water-quality data in this report represent a brief summary of the general quality of ground water within each aquifer and serve as a means of comparison to the other aquifers. The inclusion of all water-quality data collected within the basin is beyond the scope of this study. Data sets collected from the same aquifer were distinguished by citing the individual studies in which they were published. More detailed discussions and presentations of water-quality data from the aquifers and the basin can be reviewed in the published studies cited in this report.

\section{Description of Study Area}

The Red River of the North Basin, located in eastern North Dakota, northeastern South Dakota, northwestern Minnesota, and southern Manitoba, Canada (figs. 1 and 2), is covered by sediment that was formed by glacial erosion and deposition and ranges in thickness from 150 to $300 \mathrm{ft}$ (Minnesota Geological Survey, 1995; Minnesota Department of Natural Resources, 2000). Three distinct physiographic areas are recognized in the Minnesota part of the basin: (1) Red River Valley Lake Plain, (2) Lake-Washed Till Plain, and (3) Moraine (fig. 1). A fourth physiographic area, the Drift Prairie, is located predominantly in North Dakota, with smaller parts in Manitoba, South Dakota, and Minnesota (fig. 1) (Stoner and others, 1993; Lorenz and Stoner, 1996). However, because surficial aquifers were not identified in the Minnesota part of the Drift Prairie, further discussion of the area has not been included.

Clay-rich sediment was deposited by Glacial Lake Agassiz in the Red River Valley Lake Plain along the axis of the present Red River of the North and in the Lake-Washed Till Plain (fig. 1). The Red River Valley Lake Plain is relatively flat, sloping approximately $1 \mathrm{ft} / \mathrm{mi}$ along the axis of the river and approximately $5 \mathrm{ft} / \mathrm{mi}$ perpendicular to the river. The LakeWashed Till Plain is characterized by extensive wetlands and a relatively flat surface with few small ridges (Lorenz and Stoner, 1996). Glacial Lake Agassiz sediment in the Red River Valley Lake Plain and the Lake-Washed Till Plain includes (1) ancient and modern river overbank and flood-plain deposits of sand, silt, and clay; (2) offshore lake deposits of thin, flat-bedded clay and silt; (3) nearshore lake deposits of flat- to cross-bedded sand, silt, and clay; (4) thin lake sediment of flat- to crossbedded sand, silt, and clay deposited in shallow water over sand and gravel, and offshore bars and beaches; and (5) lake waveeroded glacial deposits of gravel, pebbly sand, silt, and clay deposited along the shoreline and on eroded till surfaces (Minnesota Geological Survey, 1995).

The land surface of the east-central and southeastern parts of the Red River Valley Lake Plain rises into the upland hills of the Moraine (fig. 1). The Moraine was formed by multiple glacial advances and recessions across the area (Lorenz and Stoner, 1996) and consists of unsorted and unstratified mixtures of clay, silt, sand, gravel, and boulders, commonly referred to as till (Minnesota Geological Survey, 1995). The till varies from lowrelief, flat-lying layers, to high-relief surfaces with undulations and hummocks (Minnesota Geological Survey, 1995) and is characterized by numerous lakes and wetlands (Lorenz and Stoner, 1996).

Along the western and eastern boundaries of the Red River Valley Lake Plain and within the Lake-Washed Till Plain, 


\section{Ground-Water Availability from Surficial Aquifers in the Red River of the North Basin, Minnesota}

elongated deposits of sand and gravel were laid down by glacial-drift filling of bedrock valleys, streams adjacent to glacial ice, and (or) as beach ridges formed by waves of Glacial Lake Agassiz (Lorenz and Stoner, 1996). The beach ridges (Beach Ridge aquifers when saturated and water bearing) (figs. 1 and 2) consist of shoreline and offshore deposits of sand, silt, and gravel, and are characterized by planar and cross-beds (Minnesota Geological Survey, 1995).

The aquifers discussed in this report comprise the principal surficial aquifers in and adjacent to the Minnesota part of the basin. Excluding the Beach Ridge aquifers, the eight surficial aquifers are associated with late Wisconsin-age glaciation and were likely deposited by meltwater located beneath, along, and in front of glaciers that were active across the region. Generally, the aquifers are isolated deposits of sorted and stratified sand and gravel located at the land surface or partially buried by overlying Glacial Lake Agassiz sediment or glacial till (fig. 2). The surficial aquifers are found as narrow, linear alluvium, terrace and tunnel valley deposits, thin, broad outwash plains, deltas, and beaches (Minnesota Department of Natural

Resources, 2000).

\section{Aquifer Extent and Hydrogeologic Characteristics}

The nine selected surficial aquifers (fig. 2) have been mapped and evaluated in previous reports. Excluding the Beach Ridge aquifers, the surficial aquifers range in size from $22 \mathrm{mi}^{2}$ (Middle River surficial aquifer) to $996 \mathrm{mi}^{2}$ (Pineland Sands surficial aquifer). The maximum saturated thickness of the nine surficial aquifers ranges from $70 \mathrm{ft}$ (Wadena surficial aquifer) to $200 \mathrm{ft}$ (Buffalo aquifer) (table 1). Although this study focused on the ground-water resources of these nine aquifers, additional minor surficial aquifers may exist and could provide additional sources of ground water. The ground-water resources within other minor surficial aquifers are considered to be negligible compared to the nine aquifers summarized in this study. A detailed summary of each of the nine selected surficial aquifers, in order from nearest the Red River (west) to farthest from the river (east), follows.

\section{Buffalo Aquifer}

The Buffalo aquifer is a narrow, elongate sand and gravel deposit located in the Red River Valley Lake Plain area (fig. 2). The aquifer is 1 to $2 \mathrm{mi}$ wide in the northern part of Clay County, extends southward about $36 \mathrm{mi}$, and is as wide as $9 \mathrm{mi}$ in northern Wilkin County (fig. 3). The Buffalo aquifer is $66 \mathrm{mi}^{2}$ in area (table 1).

The Buffalo aquifer is a complex, heterogeneous channelfill deposit of fine- to coarse-grained sand, cobbly gravel, silt, and clay, incised into the bed of Glacial Lake Agassiz and underlying glacial sediment. The aquifer likely was deposited in a tunnel valley by discharged meltwater beneath the terminus of a glacier (Minnesota Department of Natural Resources, 2000).

In the northern part, the aquifer is diamond-shaped in cross section, with a narrow, deep trough oriented along a north-south trending axis (Wolf, 1981). In the southern part of the aquifer, the tunnel valley likely discharged water and sediment into an ice-marginal lake, forming the large, flat-lying part of the aquifer located in northern Wilkin County (fig. 3) (Minnesota Department of Natural Resources, 2000). Across the broad southern part of the aquifer, where grain size increases with depth from fine- to coarse-grained sand, the aquifer is only $10 \mathrm{ft}$ thick and pinches out to the south (Wolf, 1981). In addition to lateral meandering, the aquifer undulates vertically, suggesting that numerous, large-scale discharges of water occurred in the tunnel valley (Minnesota Department of Natural Resources, 2000).

Grain size is increasingly finer east and west of the aquifer's north-south axis, grading from silty fine- to mediumgrained sand near the axis, to very fine-grained sand, silt, and clay at the eastern and western edges. The northern part of the aquifer consists of three distinct vertical horizons: (1) an upper layer of silty fine- to coarse-grained sand, interlayered with sandy clay; (2) a middle layer of sand and clay; and (3) a lower layer of cobbly gravel with medium- to coarse-grained sand (Schoenberg, 1998).

The Buffalo aquifer has unconfined and confined areas (Wolf, 1981). Although the aquifer is overlain by a confining layer of Glacial Lake Agassiz sediment, $25 \mathrm{mi}^{2}$ of the aquifer are unconfined along its north-south axis. In other areas, the overlying glacial sediment confines the aquifer completely (Schoenberg, 1998). The entire aquifer is underlain by a confining unit of till, which is underlain by Cretaceous sedimentary rocks or Precambrian crystalline bedrock (Wolf, 1981; Schoenberg, 1998).

The water table of the Buffalo aquifer is 5 to $15 \mathrm{ft}$ below land surface along its north-south trending axis and 30 to $40 \mathrm{ft}$ below land surface in the southwestern part of the aquifer (Schoenberg, 1998). Aquifer and saturated thicknesses of the Buffalo aquifer are summarized in table 1.

Ground-water flow in the Buffalo aquifer is to the west, possibly indicating that recharge from glacial till occurs along the aquifer's eastern margin and discharges along the western edge into the adjacent till (fig. 3). In parts of Wilkin County (fig. 3) ground-water flow in the aquifer is to the northwest and southwest. The water table in the aquifer has a maximum slope of approximately $5 \mathrm{ft} / \mathrm{mi}$ and a mean slope of approximately $1 \mathrm{ft} / \mathrm{mi}$ (Wolf, 1981). Characteristics of the aquifer are summarized in table 1 .

\section{Beach Ridge Aquifers}

Discontinuous beach ridge deposits of very fine- to medium-grained sand, with lenses of fine- to medium-grained 


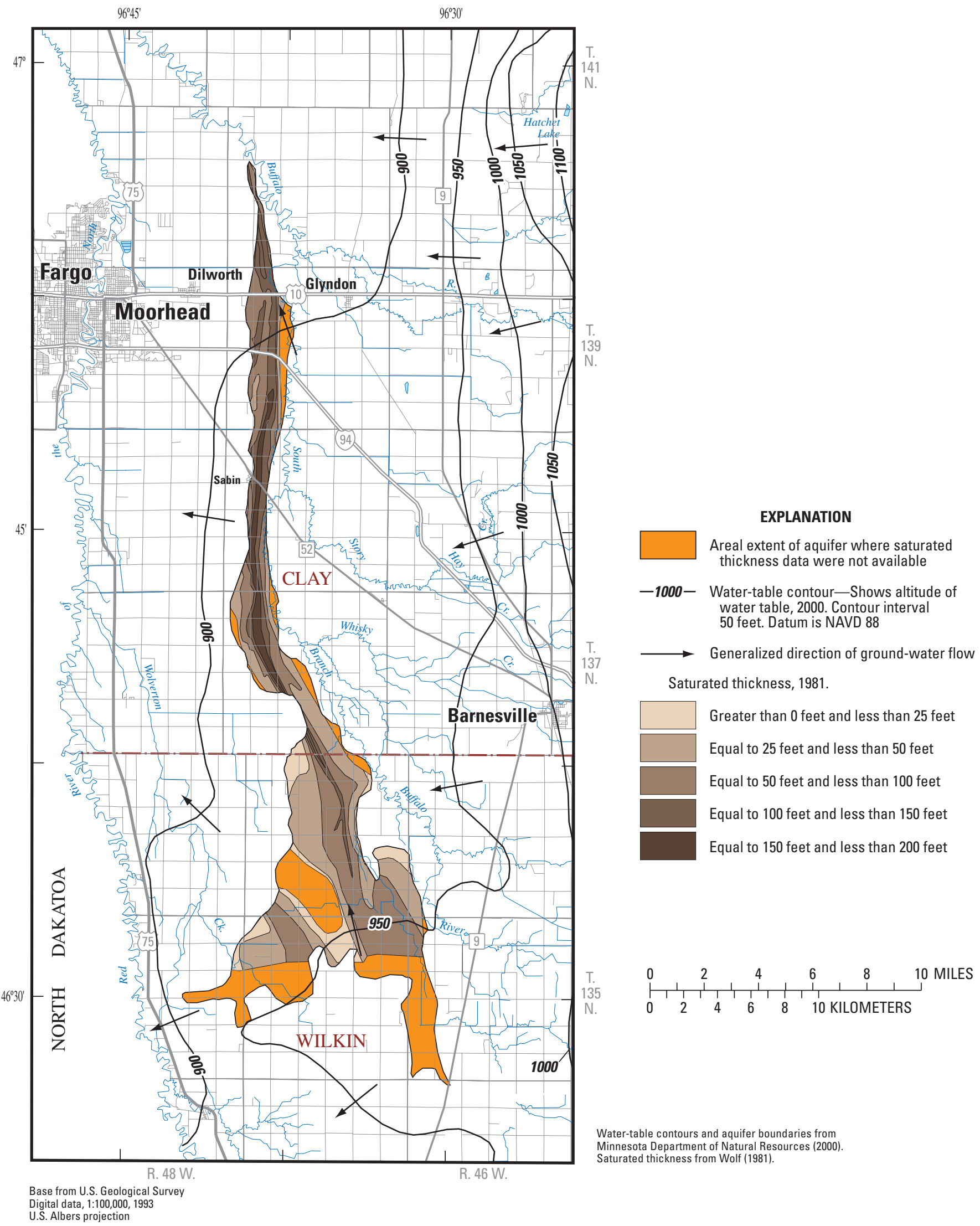

Figure 3. Generalized extent, saturated thickness, altitude of regional water table, and generalized direction of ground-water flow of Buffalo aquifer. 
gravel (referred to as Beach Ridge aquifers, when saturated and water bearing) are located throughout the Red River of the North Basin along the former shores of Glacial Lake Agassiz (figs. 1 and 2). The horizontal and vertical extents of the aquifers are highly variable. The deposits are poorly to well sorted (Stoner and others, 1993).

The Beach Ridge aquifers range in length from one to tens of miles and range from a few hundred feet in width for a single ridge to several miles wide where numerous ridges coalesce (Stoner and others, 1993). The depth to ground water in the aquifers may be as shallow as 2 to $3 \mathrm{ft}$ below land surface and is highly variable as a result of local topography (T.K. Cowdery, U.S. Geological Survey, oral commun., 2004). Characteristics of the Beach Ridge aquifers are summarized in table 1.

\section{Middle River Surficial Aquifer}

The Middle River surficial aquifer is approximately $22 \mathrm{mi}^{2}$ in area and is located in Marshall County (fig. 2). The aquifer is an alluvial and lake bar deposit located along the Middle River and extending 5 mi north-northwest of Argyle (fig. 4) and $10 \mathrm{mi}$ southeast and east of Argyle, Minnesota (Maclay and others, 1965).

The Middle River surficial aquifer consists primarily of sand and silt, with lenses of gravel. The eastern part of the aquifer is predominantly fine-grained sand and silt, with substantial amounts of clay. The central part of the aquifer, southeast of Argyle, Minnesota, consists of fine-grained sand and lenses of coarse-grained sand, gravel, and silt. The northwestern part of the aquifer is predominantly fine- to medium-grained sand, silt, and clay (Maclay and others, 1965). Ground-water flow in the aquifer is generally to the west (fig. 4) (Maclay and others, 1965). The water table is 5 to $10 \mathrm{ft}$ below land surface, and the aquifer is primarily unconfined except in the northwest where it is commonly covered with thin deposits of clay. The water table in the aquifer has a maximum slope of approximately $20 \mathrm{ft} / \mathrm{mi}$ and a mean slope of $7 \mathrm{ft} / \mathrm{mi}$ (Maclay and others, 1965). Characteristics of the aquifer are summarized in table 1.

\section{Two Rivers Surficial Aquifer}

The Two Rivers surficial aquifer is $146 \mathrm{mi}^{2}$ in area (table 1) and located in Kittson and Marshall Counties (figs. 2 and 5). The outwash aquifer trends north-northwest and extends as a 4to 5-mi-wide belt from northern Marshall County to the Minnesota-Manitoba, Canada border (fig. 5) (Maclay and others, 1967).

The northern part of the aquifer consists of lenticularly bedded deposits of sand, gravel, silt, and clay (Maclay and others, 1967). Sand and medium-grained gravel are most abundant in the middle of this river channel deposit in the central part near Lake Bronson and Halma, Minnesota (fig. 5) (Schiner, 1963). The coarser grained sand and gravel parts of the aquifer also include beds of cobbles and boulders that occur in the thicker sections of the deposit (Maclay and others, 1965). Along the margins of the aquifer, the channel deposit predominantly consists of thin layers of silt and clay. The aquifer is unconfined, excluding the western margin where it is confined by heterogeneous glacial till consisting mainly of sandy clay (Maclay and others, 1967).

The water table in the aquifer is generally less than $5 \mathrm{ft}$ below land surface, and the aquifer is entirely saturated in topographically low-lying areas. Ground-water flow is to the westsouthwest (fig. 5) (Maclay and others, 1967). Ground-water residence times within the aquifer are short due to the proximity of the water table to sources of recharge and ground-water movement within the upper parts of the aquifer to local streams, lakes, and wetlands (Maclay and others, 1967). The maximum and mean slopes of the water table are approximately 15 and $8.8 \mathrm{ft} / \mathrm{mi}$, respectively (Maclay and others, 1965, 1967). Characteristics of the aquifer, including thickness and saturated thickness, are summarized in table 1.

\section{Pelican River Sand-Plain Aquifer}

The Pelican River sand-plain aquifer is $195 \mathrm{mi}^{2}$ in area and is located in parts of Becker, Clay, and Otter Tail Counties (figs. 2 and 6). The aquifer is elongate in shape and generally is oriented north-south and extends from approximately $8 \mathrm{mi}$ north of Detroit Lakes, Minnesota, to the south to Long Lake approximately $10 \mathrm{mi}$ south of Pelican Rapids, Minnesota (fig. 6) (Miller, 1982; Minnesota Department of Natural Resources, 2000, 2002).

The lithology of the aquifer ranges from fine- to coarsegrained sand. The aquifer is bounded laterally by relatively heterogeneous glacial till, with low permeability and consists of clay, silt, sand, and gravel underlain by a gray, silty till (Miller, 1982). The northwestern part of the aquifer is covered by till deposits, and the southern part pinches out at the surface. Gravel pits located south of the aquifer may indicate that buried remnants are continuous to the south and southwest (Anderson, 1980). Aquifer and saturated thicknesses are summarized in table 1.

Ground-water flow in the northern part of the Pelican River sand-plain aquifer is to the south-southeast toward the Pelican River, Detroit and Pelican Lakes, and Lakes Melissa and Sallie, and to the west and southwest in the southern part of the aquifer and along the eastern boundary (fig. 6). The water table has a maximum slope of approximately $25 \mathrm{ft} / \mathrm{mi}$ and a mean slope of $13 \mathrm{ft} / \mathrm{mi}$ (Minnesota Department of Natural Resources, 2000, 2002). Characteristics of the aquifer are summarized in table 1 .

\section{Otter Tail Surficial Aquifer}

Although the extent of the Otter Tail surficial aquifer was initially estimated to be approximately $350 \mathrm{mi}^{2}$ (Reeder, 1972), recent studies indicate that the aquifer covers $510 \mathrm{mi}^{2}$ in Becker and Otter Tail Counties (fig. 2, table 1) (Minnesota Department of Natural Resources, 2002). The aquifer extends across the central part of Otter Tail County, into southern Becker County, 


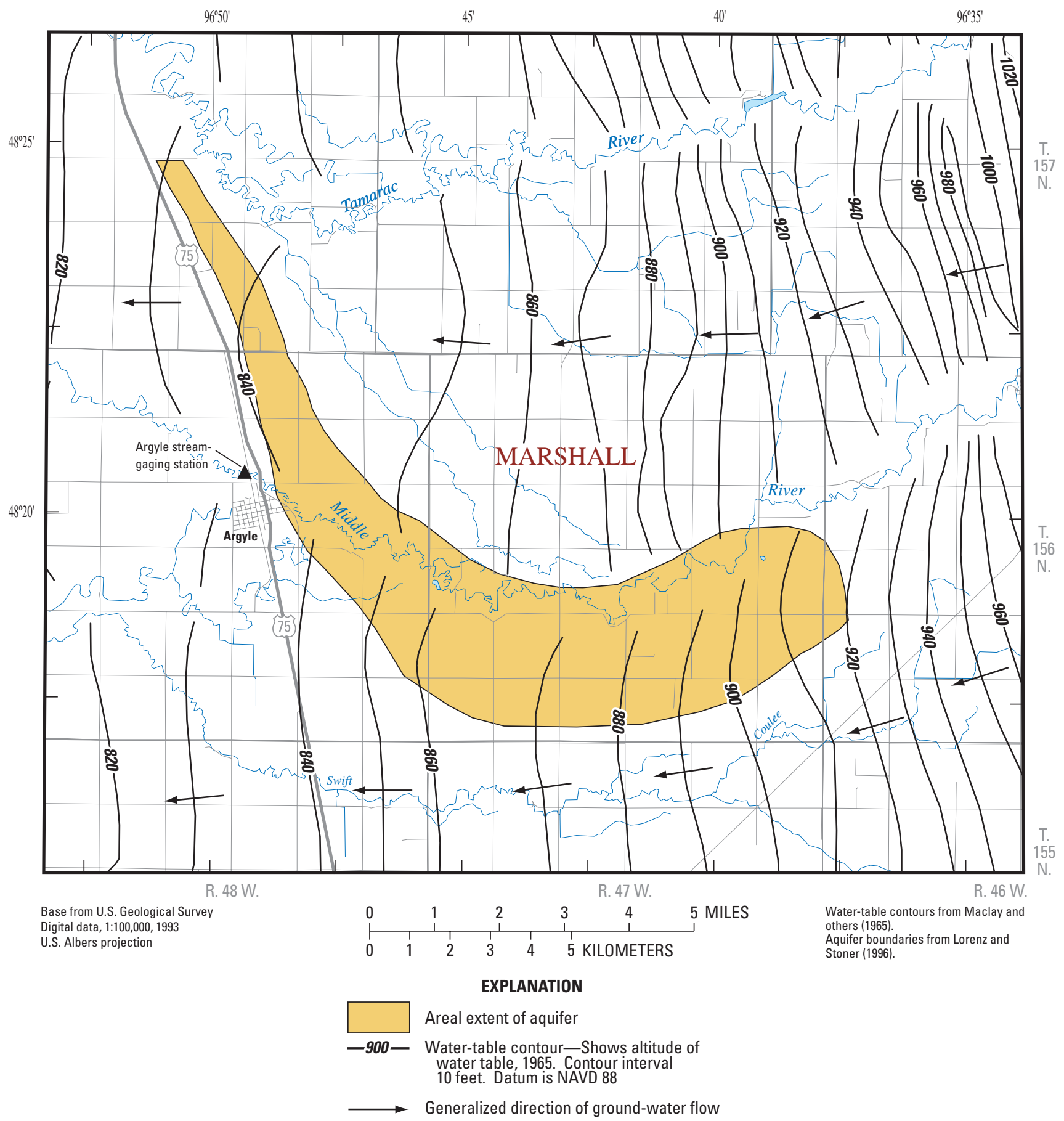

Figure 4. Generalized extent, altitude of regional water table, and generalized direction of ground-water flow of Middle River surficial aquifer. 


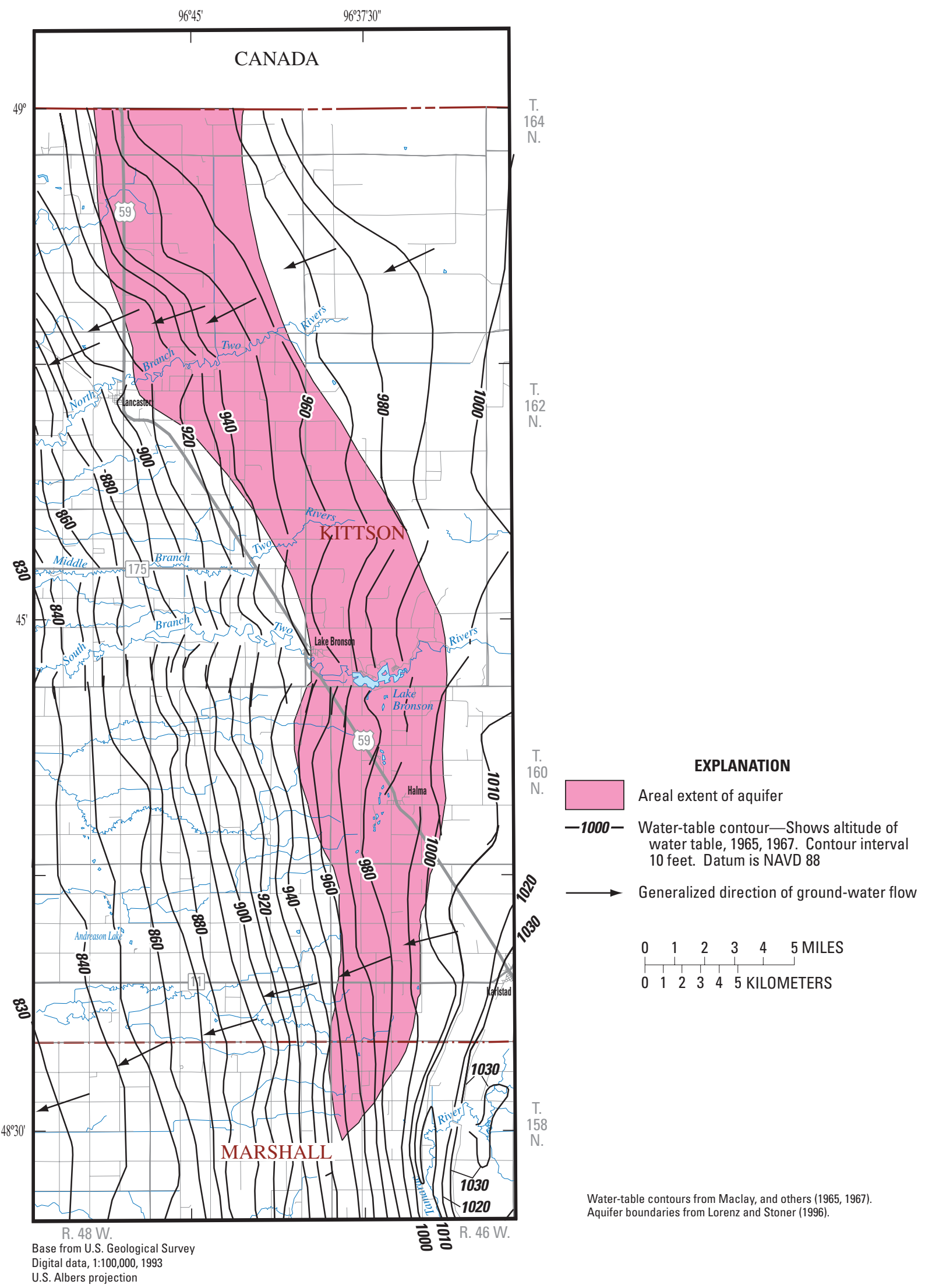

Figure 5. Generalized extent, altitude of regional water table, and generalized direction of ground-water flow of Two Rivers surficial aquifer. 


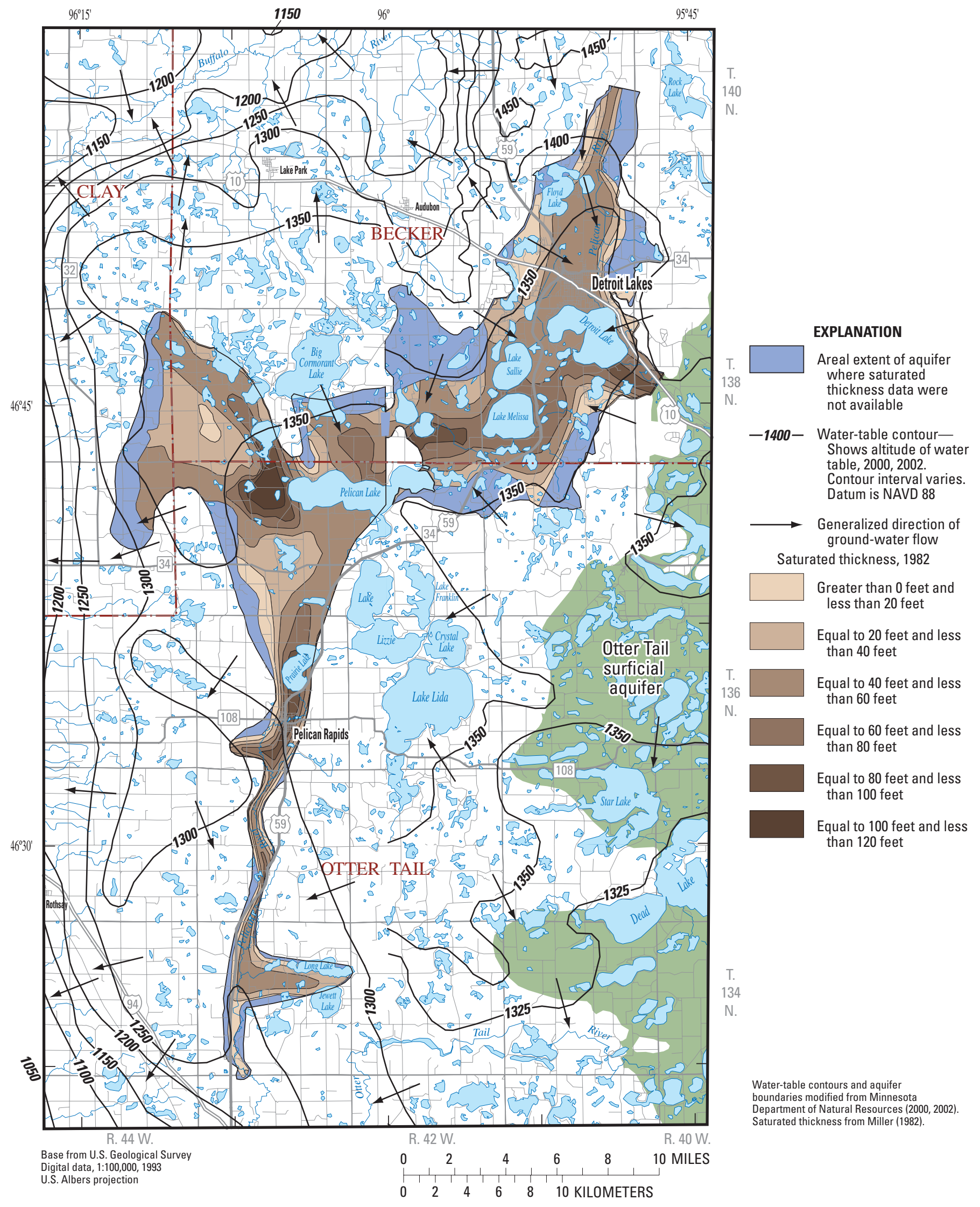

Figure 6. Generalized extent, saturated thickness, altitude of regional water table, and generalized direction of ground-water flow of Pelican River sand-plain aquifer. 
where it abuts the Pelican River sand-plain aquifer to the northwest (figs. 2 and 7) (Minnesota Department of Natural

Resources, 2002).

The Otter Tail surficial aquifer consists of ice-contact and outwash deposits, primarily well-sorted sand with varying gradations of fine- to coarse-grained sand and gravel and lenses of clay (Reeder, 1972; Anderson, 1980). Although bedrock is $200 \mathrm{ft}$ below land surface near Perham, Minnesota, and Big Pine Lake (fig. 7) (Reeder, 1972), north and northwest of Little Pine Lake (fig. 7) bedrock is more than $400 \mathrm{ft}$ below land surface (Winter and others, 1969). The aquifer is predominantly unconfined although some parts may be confined locally by clay lenses (Anderson, 1980). The depth to the aquifer's water table ranges from 0 to $70 \mathrm{ft}$ below land surface depending on local topography (Reeder, 1972). The aquifer has a saturated thickness of at least $20 \mathrm{ft}$ across $95 \mathrm{mi}^{2}$ and varies up to $5 \mathrm{ft}$ with fluctuations in the water table. Aquifer and saturated thicknesses are summarized in table 1.

Ground-water flow in the aquifer is towards the Otter Tail River (fig. 7) (and the lakes along the river) and south and west along the axis of the river. In the southern one-third of the aquifer, ground water flows north-northwest toward the Otter Tail and Leaf Rivers (fig. 7) (Reeder, 1972). The water table has a maximum slope of approximately $25 \mathrm{ft} / \mathrm{mi}$ and a mean slope of $9 \mathrm{ft} / \mathrm{mi}$ (Minnesota Department of Natural Resources, 2000, 2002). Aquifer characteristics are summarized in table 1.

\section{Wadena Surficial Aquifer}

The Wadena surficial aquifer, located in Douglas, Otter Tail, Todd, and Wadena Counties, is the fourth-largest surficial aquifer $\left(397 \mathrm{mi}^{2}\right)$ within the study area (table 1$)$. Although the aquifer is contiguous with and part of the larger more extensive north-south trending Pineland Sands surficial aquifer (figs. 2, 8, and 9) (Lindholm, 1970), the two aquifers are considered and discussed separately in this report.

The Wadena surficial aquifer consists of well-sorted, glaciofluvial, outwash sand with minor amounts of gravel and clay. The median grain size of the aquifer is medium- to coarsegrained sand. Calcareous, sandy till underlies the aquifer, and most of the Wadena area also is underlain by at least one confined aquifer consisting of lenses of sand and gravel within and beneath the till (Lindholm, 1970; Lindgren, 2002).

Although regional textural variations have been mapped in the Wadena surficial aquifer, lateral and vertical variations also are common across relatively short distances (Lindholm, 1970). Coarse-grained sediment generally occurs within former drainages and is most common in the western and southern parts of the aquifer. The coarse fraction is predominantly carbonate rock fragments, with minor amounts of quartz and various igneous rocks. Fine- to medium-grained sand is found predominately in the eastern and southeastern parts of the aquifer between the Partridge River and the Leaf River, and southeast of the Partridge River, respectively (fig. 8) (Lindholm, 1970).
Depth to bedrock varies across the extent of the aquifer. Granite is less than $100 \mathrm{ft}$ from land surface in the southeast part of the aquifer. However, greater than $250 \mathrm{ft}$ of glacial till are reported in the western part (Lindholm, 1970). The Wadena surficial aquifer is thickest in topographically low areas and thinnest across the tops of buried drumlins (Lindholm, 1970). Aquifer and saturated thicknesses are summarized in table 1.

Depth to ground water in the aquifer is dependent on seasonal variations in recharge and discharge (Lindgren, 2002) and varies from 0 to $25 \mathrm{ft}$ (Lindholm, 1970). In upland areas the water table generally is 10 to $20 \mathrm{ft}$ below land surface and between 0 and $10 \mathrm{ft}$ in low-lying areas. Regional ground-water flow is north-northeast toward the Leaf and Crow Wing Rivers. North of the Leaf River, ground water flows toward the river. Local ground-water flow is toward local depressions and major rivers, streams, and tributaries (fig. 8). The mean gradient of the aquifer's water table is $8 \mathrm{ft} / \mathrm{mi}$, with a maximum gradient of approximately $25 \mathrm{ft} / \mathrm{mi}$ (Lindholm, 1970). Characteristics of the aquifer are summarized in table 1.

\section{Pineland Sands Surficial Aquifer}

The Pineland Sands surficial aquifer is the largest surficial aquifer located in the study area and covers $996 \mathrm{mi}^{2}$ in Becker, Cass, Hubbard, Todd, and Wadena Counties (figs. 2 and 9).

The aquifer likely was deposited by meltwater during three separate periods of glacial recession and is surrounded by surface deposits of glacial till (Wright, 1962; Helgesen, 1977). Poorly sorted, clay-rich till also underlies most of the surficial outwash aquifer and forms isolated surface deposits throughout the southern part of the aquifer and in southwestern Hubbard County (Helgesen, 1977). The aquifer consists of very finegrained sand to fine gravel and generally increases in grain size from south to north. Along the northwestern part of the aquifer, cobbles and boulders are common (Helgesen, 1977).

In the Straight River Basin area (fig. 9), the aquifer consists of transmissive, coarse-grained sand and gravel deposits in the north and fine-grained sand and gravel in the south (Stark and others, 1994). The aquifer is underlain by till, which consists of unsorted clay, silt, sand, gravel, and boulders, and transmits only minor amounts of water (Stark and others, 1994). In the Straight River Basin area, the aquifer is unconfined except in locations where thin deposits of clay, silt, and (or) peat form local confining layers (Stark and others, 1994).

The Pineland Sands surficial aquifer is thickest in the northern one-half of the aquifer and thins towards the outer boundaries. Isolated areas of outwash extend beyond the northern boundary of the aquifer (Helgesen, 1977). Aquifer and saturated thicknesses are summarized in table 1.

Ground-water flow in the Pineland Sands surficial aquifer is generally to the south and mimics topographic relief (fig. 9) (Helgesen, 1977). Ground-water flow direction within the Straight River Basin area is to the east-southeast and southeast (fig. 9) (Stark and others, 1994). Flow paths in the aquifer generally are short due to discharge to streams, lakes, and wetlands. 


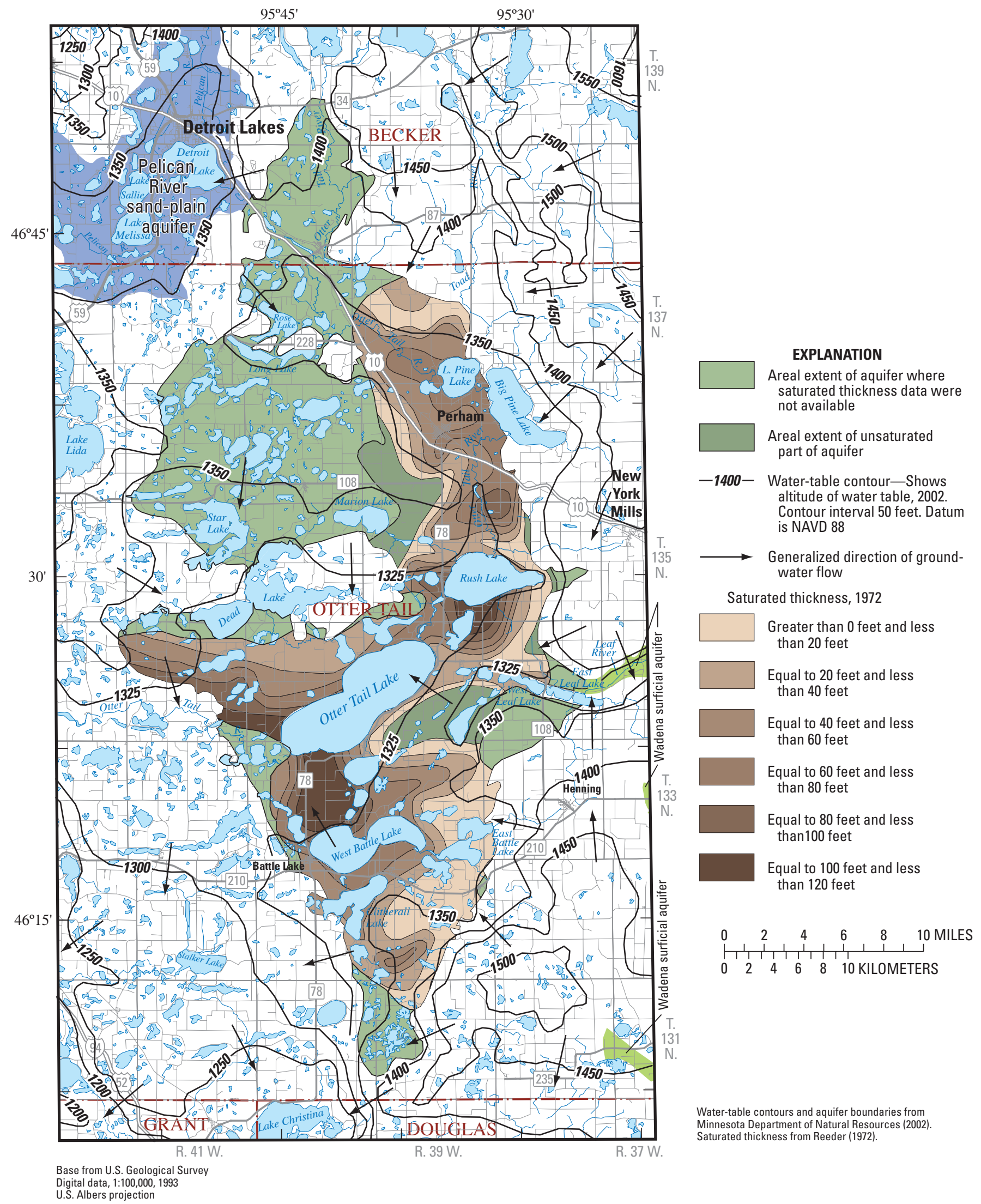

Figure 7. Generalized extent, saturated thickness, altitude of regional water table, and generalized direction of ground-water flow of Otter Tail surficial aquifer. 


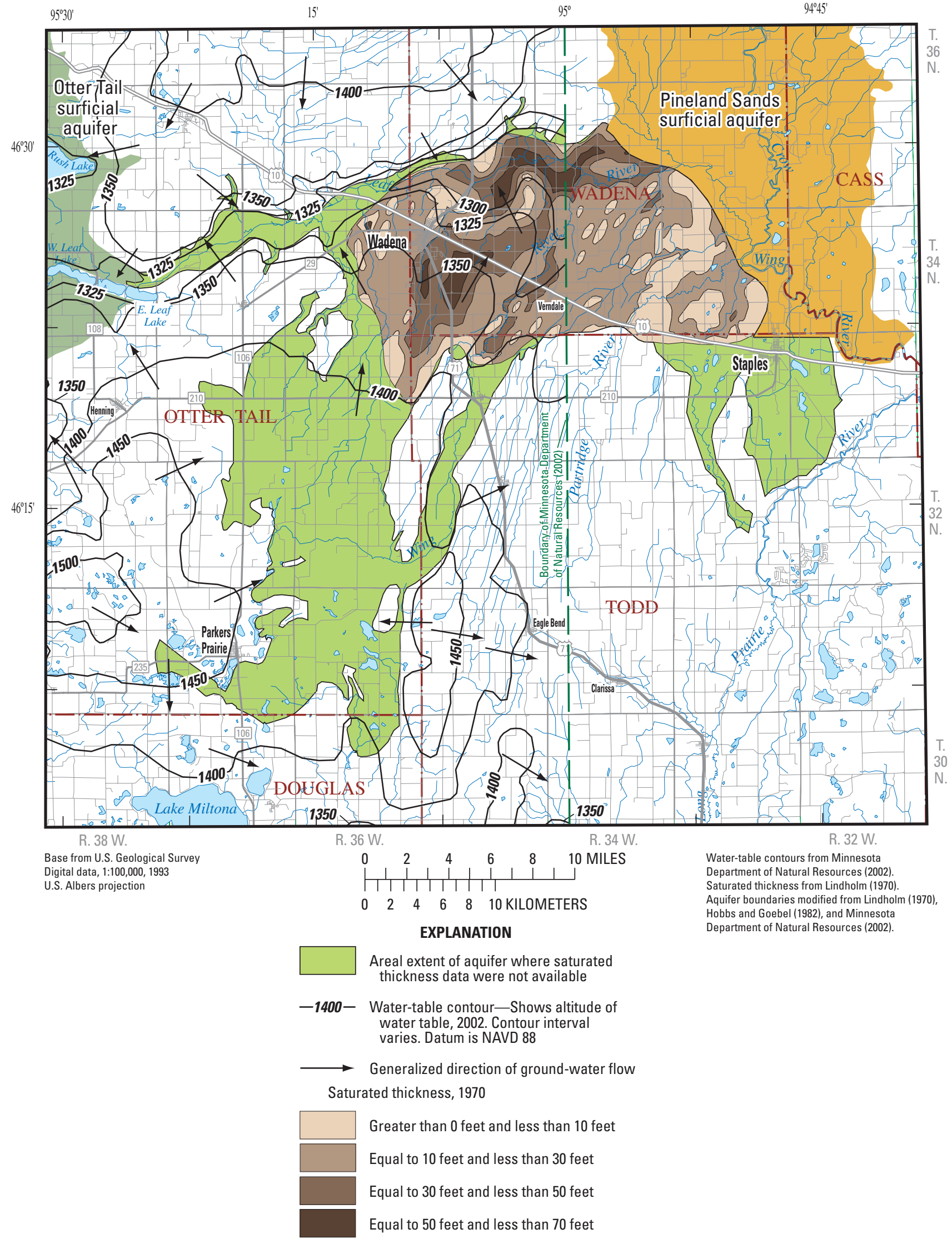

Figure 8. Generalized extent, saturated thickness, altitude of regional water table, and generalized direction of ground-water flow of Wadena surficial aquifer. 


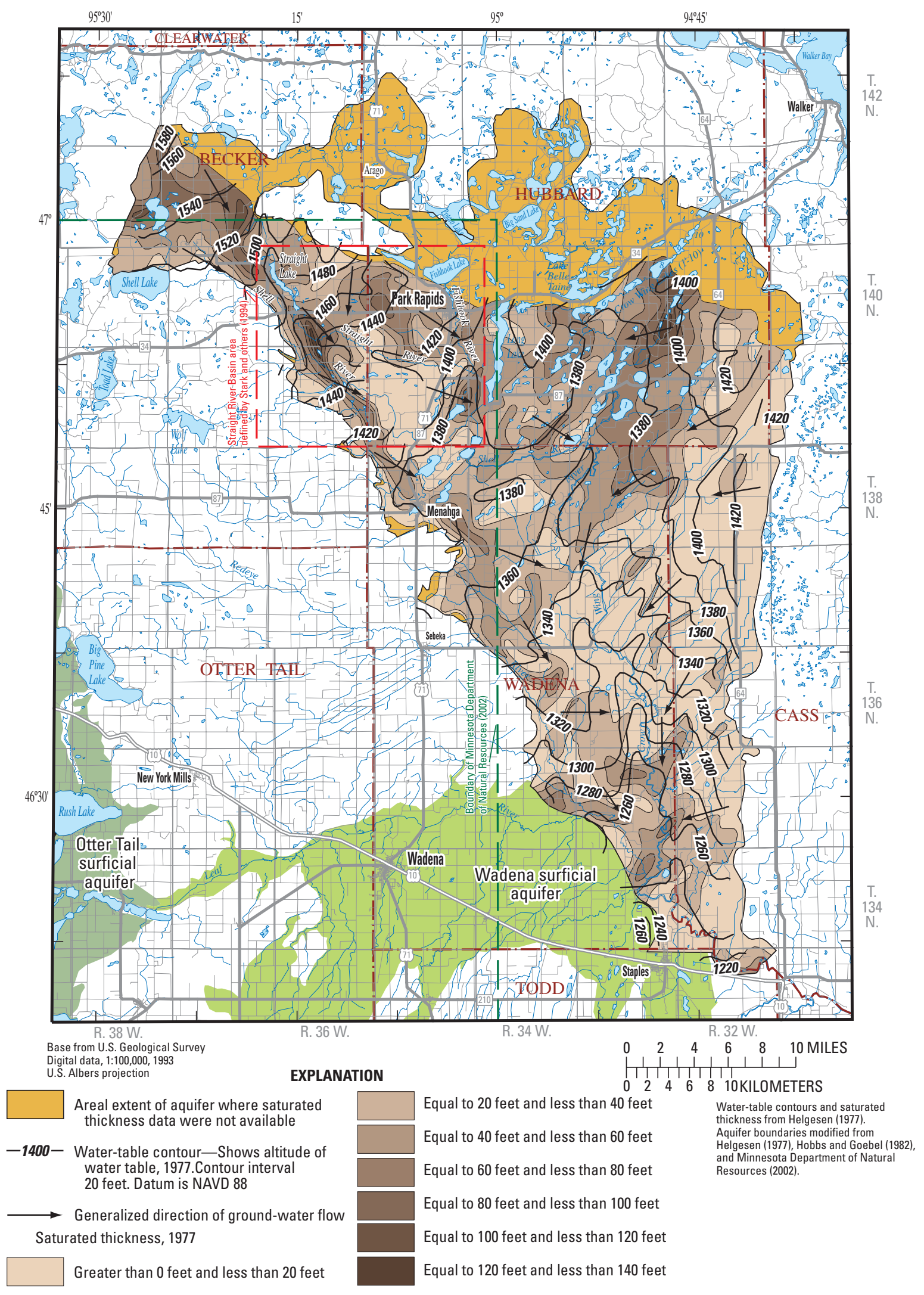

Figure 9. Generalized extent, saturated thickness, altitude of water table, and generalized direction of ground-water flow of Pineland Sands surficial aquifer. 
Most of the land is agricultural fields or forest and is characterized by flat to gently rolling topography (Helgesen, 1977). In the Straight River Basin area, the water table slopes to the southeast at approximately $10 \mathrm{ft} / \mathrm{mi}$, toward the Straight, Fishhook, and Shell Rivers, and locally towards adjacent surface water and pumping wells. Depth to the water table ranges between 0 and $30 \mathrm{ft}$ (Stark and others, 1994). Characteristics of the Pineland Sands surficial aquifer are summarized in table 1.

\section{Bemidji-Bagley Surficial Aquifer}

The primary source of ground water in Beltrami, Cass, Clearwater, and Hubbard Counties is the unconfined and uppermost-confined Bemidji-Bagley aquifers (Stark and others, 1991). The unconfined aquifer is hydraulically separated from the uppermost-confined aquifer by a fine-grained, confining unit of till or lake deposits (Stark and others, 1991). For the purposes of assessing the ground-water resources, only the Bemidji-Bagley surficial aquifer (the unconfined part of the aquifer) is discussed in this report (figs. 2 and 10).

The total area of the Bemidji-Bagley surficial aquifer is $630 \mathrm{mi}^{2}$ (table 1). The aquifer generally consists of glacial outwash and lake sediment deposits of coarse-grained sand and gravel in the north and finer grained sand and gravel to the south (Stark and others, 1991). Aquifer and saturated thicknesses are summarized in table 1.

Ground-water flow in the Bemidji-Bagley surficial aquifer is generally northeast and east towards the Mississippi and Clearwater Rivers (fig. 10). Maximum and mean slopes of the water table in the surficial aquifer are approximately 50 and $7 \mathrm{ft} / \mathrm{mi}$, respectively (Stark and others, 1991). Characteristics of the aquifer are summarized in table 1.

\section{Ground-Water Availability}

Knowledge of ground-water recharge, discharge, and storage is fundamental to understanding the availability of ground water. For the purposes of this study, ground-water availability in the surficial aquifers was evaluated primarily on the basis of the rate of ground-water inflow (the total sources of water to an aquifer) and the maximum volume of ground water capable of being stored in an aquifer. Additional means of evaluating ground-water availability included comparing theoretical and actual rates of ground-water pumping and uses of ground water withdrawn from the aquifers.

Under natural conditions, the volume of stored ground water in an aquifer is in long-term equilibrium (steady-state), and total ground-water recharge is approximately equal to total discharge. The balance (water budget) between the sources and losses controls ground-water levels and storage volumes. Therefore, stored ground water acts as a reservoir, stabilizing an aquifer's water budget and minimizing fluctuations caused during periods of increased water inflow and outflow. When aquifer recharge exceeds discharge, ground-water levels and storage increase. Conversely, ground-water levels and storage decline during periods when discharge exceeds recharge.

The pumping of ground water from wells changes natural flow conditions in aquifers. Water withdrawn from wells is provided by a combination of increased ground-water recharge, increased inflow from other sources (such as rivers and streams), decreased natural discharge, or reduction of groundwater storage. Responses to pumping are temporary and occur as the aquifer readjusts to pumping stress and the changes in storage, recharge, and discharge. As an aquifer re-establishes equilibrium, changes in storage diminish to zero, and total ground-water inflows balance outflows. Thus, long-term sources of water to pumping wells come from variations in the amount of water entering or leaving the aquifer system. The time required for an aquifer to establish a new equilibrium is a function of the characteristics of the aquifer and the placement and pumping rates of wells.

\section{Water-Budget Estimates}

For the purposes of estimating water budgets and evaluating the availability of ground water for the surficial aquifers, a schematic diagram of a surficial aquifer system showing potential sources and losses of water is displayed in figure 11. Although figure 11 is a simplified cross section of a surficial aquifer and its major sources and losses of ground water, much of an aquifer's inflow and outflow of water are influenced by and related to complex surficial and sub-surficial processes. For that reason, all of the sources and losses of water in each of the surficial aquifers are not determined and (or) known; quantifying specific inflows and outflows for local parts of each aquifer was beyond the scope of this study.

The general sources of water to the surficial aquifers (and inflow components in the water-budget estimations) include (1) infiltration of precipitation to the water-table (referred to as areal recharge in general and as net areal recharge when the loss of water by evapotranspiration is not included as a separate component of the water budget); (2) flow from surface water (rivers, streams, lakes, and wetlands); and (3) flow into the aquifers across their boundaries from adjacent geologic units, including confined aquifers and confining units (table 2). In general, net areal recharge is greatest in the unconfined parts of the aquifers. Losses of water from the surficial aquifers are the result of (1) evapotranspiration directly from the water table; (2) flow to surface water; (3) ground-water flow across the aquifers' boundaries to adjacent geologic units (including aquifers and confining units); and (4) withdrawals of ground water by pumping wells (table 2).

The surficial aquifers in the study area are regarded as steady-state systems, where variations in the ground-water table and storage volume are minimal over time and sources of water to the aquifers will be equal to losses. Although each of the surficial aquifers discussed in this study may not contain all of the sources and losses of water included in figure 11, the schematic diagram provides a conceptual model for the surficial aquifers. 
$95^{\circ} 30^{\prime}$

$15^{\prime}$

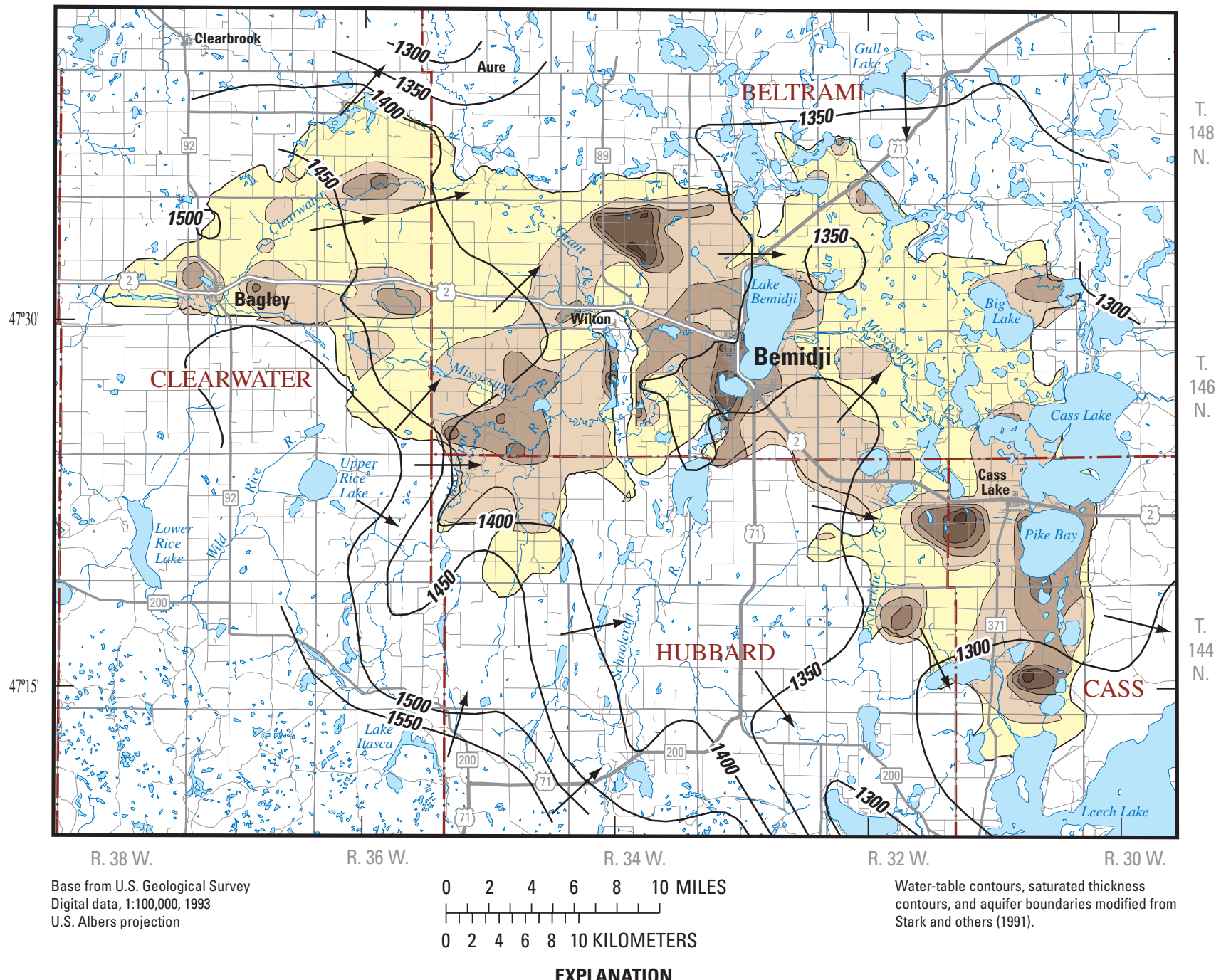

EXPLANATION

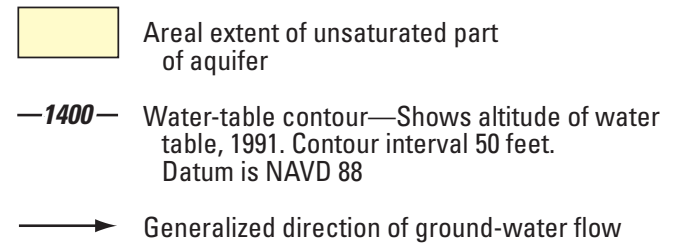

Saturated thickness, 1991

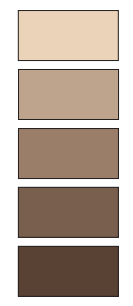

Greater than 0 feet and less than 20 feet

Equal to 20 feet and less than 40 feet

Equal to 40 feet and less than 60 feet

Equal to 60 feet and less than 80 feet

Equal to 80 feet and less than 100 feet

Figure 10. Generalized extent, saturated thickness, altitude of regional water table, and generalized direction of ground-water flow of Bemidji-Bagley surficial aquifer. 


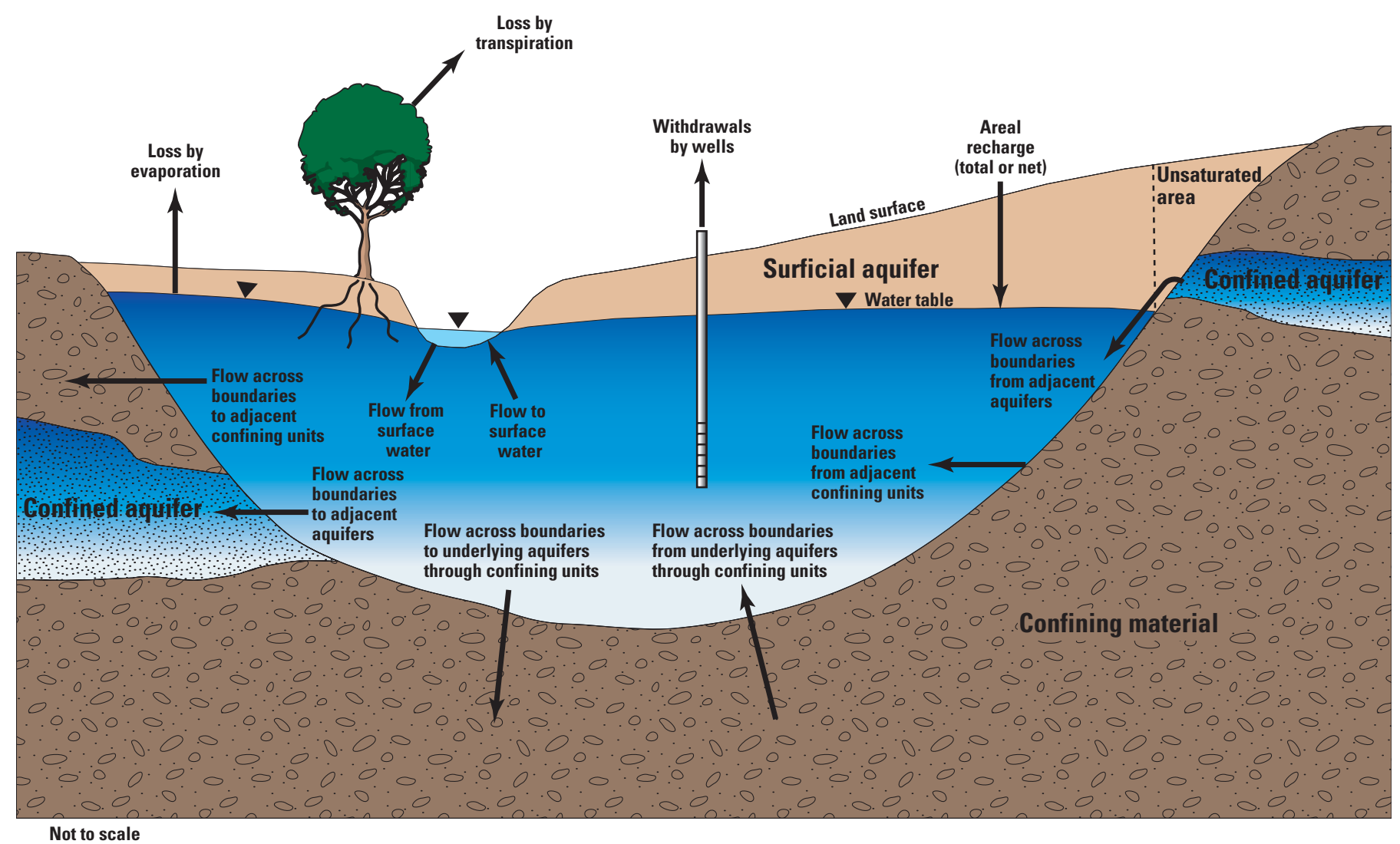

Figure 11. Schematic diagram of a surficial aquifer system showing potential sources and losses of water.

Water budgets of the surficial aquifers are summarized on the basis of the assumption of steady-state conditions (where sources equal losses). However, only total sources of water were available for some of the aquifers, and water-budget losses (when known) are reported as percentages of the total sources. As a result, sources and losses of water in many of the aquifers' water budgets are not equal but represent steady state.

\section{Buffalo Aquifer}

On the basis of long-term climatic records, normal mean annual precipitation in the area of the Buffalo aquifer is approximately 20 in. (23,000 Mgal/yr) (Baker and Kuehnast, 1978). The sources and losses of water for the Buffalo aquifer are described in the following sections and were determined by Schoenberg (1998) and summarized in tables 2 and 3. However, the water budget does not represent steady-state conditions. On the basis of water-budget components defined by Schoenberg (1998), the total flow through the aquifer was estimated to be 3,707 Mgal/yr (table 2).

\section{Sources of Water}

Measurements collected from three water-table wells by Schoenberg (1998) estimated a mean net areal recharge rate of 4.8 in/yr. Schoenberg (1998, table 3) estimated that the annual volume of water recharging the unconfined part of the Buffalo aquifer $\left(25 \mathrm{mi}^{2}\right.$ ) was $407 \mathrm{Mgal} / \mathrm{yr}$, accounting for 11 percent of the sources of water to the aquifer (table 3 ).

Additional ground-water flow to the aquifer occurred as inflow from the Buffalo River and its tributaries. From February to December 1993, flow to the aquifer from the river and its tributaries was estimated to be as much as 3,300 Mgal/yr (Schoenberg, 1998; table 3) or 89 percent of the aquifer's total water sources (table 3 ). Although inflow to the aquifer across its boundaries (from adjacent and overlying Glacial Lake Agassiz sediment and underlying till layers) is considered negligible (Schoenberg, 1998; table 3), the total volume of water flowing to the aquifer from adjacent units across its entire extent may be substantial (Wolf, 1981).

\section{Losses of Water}

The Buffalo aquifer discharges primarily into the Buffalo River and its South Branch and as outflow across the boundaries of the aquifer. Although not measured, it is believed that substantial volumes of ground water flow from the aquifer through the confining glacial sediment to surface water laterally into Glacial Lake Agassiz sediment and (or) vertically into underlying glacial till (Wolf, 1981). Ground-water evapotranspiration from the aquifer itself is negligible, except from local gravel pits that intersect the water table (Wolf, 1981). Additional losses of water occur from ground-water pumping. Substantial ground-water withdrawals began in 1948, and from 1951-60, 
Table 2. Water budgets for selected surficial aquifers in Red River of the North Basin, Minnesota.

[Mgal, millions of gallons; $\mathrm{mi}^{2}$, square miles; in/yr, inches per year; Mgal/yr, millions of gallons per year; --, data not available; $\mathrm{ft}^{3} / \mathrm{s}$, cubic feet per second]

\begin{tabular}{|c|c|c|c|c|c|c|c|c|c|c|}
\hline \multirow[b]{2}{*}{$\begin{array}{l}\text { Aquifer name } \\
\text { (reference) }\end{array}$} & \multirow[b]{2}{*}{ Method of determination } & \multirow[b]{2}{*}{$\begin{array}{l}\text { Maximum } \\
\text { aquifer } \\
\text { storage }^{1} \\
\text { (Mgal) }\end{array}$} & \multirow[b]{2}{*}{$\begin{array}{l}\text { Area of } \\
\text { aquifer } \\
\left(\mathrm{mi}^{2}\right)\end{array}$} & \multirow{2}{*}{$\begin{array}{c}\text { Year of } \\
\text { areal } \\
\text { recharge } \\
\text { data }^{2} \\
\text { (dimension- } \\
\text { less) }\end{array}$} & \multirow[b]{2}{*}{$\begin{array}{l}\text { Mean areal } \\
\text { recharge } \\
\text { rate }^{2} \text { [range] } \\
\text { (in/yr) }\end{array}$} & \multirow[b]{2}{*}{$\begin{array}{l}\text { Percentage of } \\
\text { mean areal } \\
\text { recharge to } \\
\text { mean annual } \\
\text { precipitation }\end{array}$} & \multicolumn{3}{|c|}{ Sources of water to aquifer } & \multirow{2}{*}{$\begin{array}{c}\text { Total } \\
\text { sources } \\
\text { (inflows) of } \\
\text { water to the } \\
\text { aquifer } \\
\text { (Mgal/yr) }\end{array}$} \\
\hline & & & & & & & $\begin{array}{c}\text { Mean areal } \\
\text { recharge } \\
\text { (area } \mathrm{x} \\
\text { rate) } \\
\text { (Mgal/yr) }\end{array}$ & $\begin{array}{c}\text { Flow from } \\
\text { surface } \\
\text { water } \\
\text { (Mgal/yr) }\end{array}$ & $\begin{array}{c}\text { Flow across } \\
\text { boundaries } \\
\text { (Mgal/yr) }\end{array}$ & \\
\hline $\begin{array}{l}\text { Buffalo aquifer } \\
\text { (Schoenberg, 1998) }\end{array}$ & $\begin{array}{l}\text { hydrograph } \\
\text { analysis }\end{array}$ & 270,000 & 25 & 1993 & $\begin{array}{c}4.8 \\
{[3.6-5.5]}\end{array}$ & 23 & 407 & 3,300 & -- & 3,707 \\
\hline Beach Ridge aquifers & -- & -- & -- & -- & -- & -- & -- & -- & -- & -- \\
\hline $\begin{array}{l}\text { Middle River surficial aquifer } \\
\text { (Maclay and others, 1965) }\end{array}$ & $\begin{array}{l}\text { infiltration } \\
\text { capacity of soils }\end{array}$ & 4,600 & 22 & 1962 & $\begin{array}{c}3 \\
{[2-4]}\end{array}$ & 16 & 1,100 & -- & 27 & 1,130 \\
\hline $\begin{array}{l}\text { Two Rivers surficial aquifer } \\
\text { (Maclay and others, 1965, 1967) }\end{array}$ & $\begin{array}{l}\text { infiltration } \\
\text { capacity of soils }\end{array}$ & 400,000 & 146 & 1962 & $\begin{array}{c}2.5 \\
{[1-4]}\end{array}$ & 11 & 6,300 & -- & 200 & 6,500 \\
\hline \multirow[t]{2}{*}{$\begin{array}{l}\text { Pelican River sand-plain aquifer } \\
\text { (Miller, 1982) }\end{array}$} & $\begin{array}{l}\text { steady-state } \\
\text { "Detroit Lakes" simulation }\end{array}$ & 300,000 & 195 & $1979-80$ & $\begin{array}{c}4.7 \\
{[4.5-4.9]}\end{array}$ & -- & 5,500 & 1,900 & 1,500 & 8,900 \\
\hline & $\begin{array}{l}\text { steady-state } \\
\text { "Scrambler" simulation }\end{array}$ & 300,000 & 195 & $1979-80$ & $\begin{array}{c}4.7 \\
{[4.5-4.97]}\end{array}$ & -- & 3,800 & 1,100 & -- & 4,900 \\
\hline $\begin{array}{l}\text { Otter Tail surficial aquifer } \\
\text { (Reeder, 1972) }\end{array}$ & $\begin{array}{l}\text { hydrograph } \\
\text { analysis }\end{array}$ & 500,000 & 510 & 1969 & $\begin{array}{c}5.5 \\
{[3-6]}\end{array}$ & 27 & 49,000 & -- & 2,000 & 51,000 \\
\hline $\begin{array}{l}\text { Wadena surficial aquifer } \\
\text { (Lindgren, 2002) }\end{array}$ & $\begin{array}{l}\text { numerical (regional) } \\
\text { steady-state simulation }\end{array}$ & 150,000 & 397 & 1998-99 & $\begin{array}{c}12.7 \\
{[11.5-13.9]}\end{array}$ & -- & 67,000 & 1,000 & 24,000 & 92,000 \\
\hline $\begin{array}{l}\text { Pineland Sands surficial aquifer } \\
\text { (Helgesen, 1977) }\end{array}$ & steady-state simulation & $1,000,000$ & 996 & $1971-76$ & 5.1 & -- & 58,000 & 6,000 & 6,000 & 70,000 \\
\hline $\begin{array}{l}\text { Bemidji-Bagley surficial aquifer } \\
\text { (Stark and others, 1991) }\end{array}$ & $\begin{array}{l}\text { hydrograph } \\
\text { analysis }\end{array}$ & 250,000 & 630 & $1986-87$ & $\begin{array}{c}4 \\
{[4-8]}\end{array}$ & 20 & 44,000 & -- & -- & 44,000 \\
\hline
\end{tabular}

$\begin{array}{ll}\text { Bemidji-Bagley surficial aquifer } & \text { hydrograph } \\ \text { (Stark and others, 1991) } & \text { analysis }\end{array}$ 
[Mgal, millions of gallons; $\mathrm{mi}^{2}$, square miles; in/yr, inches per year; Mgal/yr, millions of gallons per year; --, data not available; $\mathrm{ft}^{3} / \mathrm{s}$, cubic feet per second]

\begin{tabular}{|c|c|c|c|c|c|c|c|}
\hline \multirow[b]{2}{*}{$\begin{array}{c}\text { Aquifer name } \\
\text { (reference) }\end{array}$} & \multirow[b]{2}{*}{ Method of determination } & \multicolumn{4}{|c|}{ Losses of water from aquifer } & \multirow[b]{2}{*}{$\begin{array}{l}\text { Total losses } \\
\text { (outflows) of } \\
\text { water from } \\
\text { aquifer } \\
\text { (Mgal/yr) }\end{array}$} & \multirow{2}{*}{$\begin{array}{c}\text { Differences } \\
\text { between } \\
\text { sources and } \\
\text { losses of } \\
\text { water in } \\
\text { aquifer } \\
\text { (Mgal/yr) }\end{array}$} \\
\hline & & $\begin{array}{l}\text { Evapo- } \\
\text { trans- } \\
\text { piration } \\
\text { (Mgal/yr) }\end{array}$ & $\begin{array}{l}\text { Flow to } \\
\text { surface } \\
\text { water }^{4} \\
\text { (Mgal/yr) }\end{array}$ & $\begin{array}{c}\text { Flow across } \\
\text { boundaries }{ }^{4} \\
\text { (Mgal/yr) }\end{array}$ & $\begin{array}{c}\text { Withdrawals } \\
\text { by pumping } \\
\text { wells }{ }^{2} \\
\text { (Mgal/yr) }\end{array}$ & & \\
\hline
\end{tabular}

Buffalo aquifer

(Schoenberg, 1998)

hydrograph analysis

$--$

Beach Ridge aquifers

Middle River surficial aquifer infiltration capacity of soils (Maclay and others, 1965)

Two Rivers surficial aquifer (Maclay and others, 1965, 1967)

infiltration capacity of soils

Pelican River sand-plain aquifer steady-state "Detroit

(Miller, 1982)

\begin{abstract}
Lakes" simulation
\end{abstract}
steady-state

"Scrambler" simulation

Otter Tail surficial aquifer

(Reeder, 1972)

hydrograph

analysis

Wadena surficial aquifer

numerical (regional)

(Lindgren, 2002) steady-state simulation

408

408

3,299

Losses include withdrawals by wells

(Minnesota Department of Natural

Resources, 2003) and exclude flow across

boundaries (to Glacial Lake Agassiz

sediment and confined till).

-- $\quad$ No water-budget data available.

1,101 Sources include areal recharge and flow across boundaries; losses include withdrawals by wells (Minnesota

Department of Natural Resources, 2003).

6,060 Sources include areal recharge and flow across boundaries; losses include withdrawals by wells (Minnesota Department of Natural Resources, 2003).

$0 \quad$ Steady-state simulation.

$0 \quad$ Steady-state simulation.

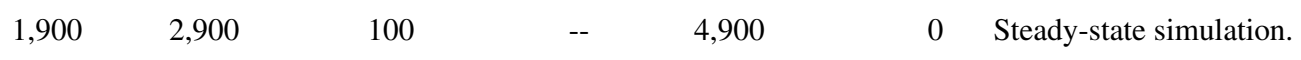

$\begin{array}{lll}-- & -- & 2,000\end{array}$

2,000

49,000

Includes only sources of water and losses of water across boundaries to adjacent aquifers.

$\begin{array}{llll}32,000 & 42,000 & 16,000 & 2,000 \quad 92,000\end{array}$

$0 \quad$ Surficial aquifer system only; simulated pumping of $6.45 \mathrm{ft}^{3} / \mathrm{s}$ in 1997-98; negligible flow across boundaries to/from the adjacent (confined) aquifer. 
Table 2. Water budgets for selected surficial aquifers in Red River of the North Basin, Minnesota.-Continued

[Mgal, millions of gallons; $\mathrm{mi}^{2}$, square miles; in/yr, inches per year; Mgal/yr, millions of gallons per year; --, data not available; $\mathrm{ft}^{3} / \mathrm{s}$, cubic feet per second]

\begin{tabular}{|c|c|c|c|c|c|c|c|c|}
\hline \multirow[b]{2}{*}{$\begin{array}{l}\text { Aquifer name } \\
\text { (reference) }\end{array}$} & \multirow[b]{2}{*}{ Method of determination } & \multicolumn{4}{|c|}{ Losses of water from aquifer } & \multirow[b]{2}{*}{$\begin{array}{c}\text { Total losses } \\
\text { (outflows) of } \\
\text { water from } \\
\text { aquifer } \\
\text { (Mgal/yr) }\end{array}$} & \multirow{2}{*}{$\begin{array}{c}\text { Differences } \\
\text { between } \\
\text { sources and } \\
\text { losses of } \\
\text { water in } \\
\text { aquifer } \\
\text { (Mgal/yr) }\end{array}$} & \multirow[b]{2}{*}{ Explanation of estimated water budget } \\
\hline & & $\begin{array}{l}\text { Evapo- } \\
\text { trans- } \\
\text { piration } \\
\text { (Mgal/yr) }\end{array}$ & $\begin{array}{l}\text { Flow to } \\
\text { surface } \\
\text { water }^{4} \\
\text { (Mgal/yr) }\end{array}$ & $\begin{array}{c}\text { Flow across } \\
\text { boundaries } \\
\text { (Mgal/yr) }\end{array}$ & $\begin{array}{c}\text { Withdrawals } \\
\text { by pumping } \\
\text { wells }{ }^{2} \\
\text { (Mgal/yr) }\end{array}$ & & & \\
\hline $\begin{array}{l}\text { Pineland Sands surficial aquifer } \\
\text { (Helgesen, 1977) }\end{array}$ & steady-state simulation & 5,000 & 65,000 & -- & -- & 70,000 & 0 & $\begin{array}{l}\text { Steady-state simulation; excludes } \\
\text { withdrawals by wells. }\end{array}$ \\
\hline $\begin{array}{l}\text { Bemidji-Bagley surficial aquifer } \\
\text { (Stark and others, 1991) }\end{array}$ & hydrograph analysis & -- & -- & -- & -- & -- & 44,000 & $\begin{array}{l}\text { Sources include areal recharge; losses } \\
\text { unknown. }\end{array}$ \\
\hline
\end{tabular}

(Stark

${ }^{1}$ Aquifer storage from published information or estimated from saturated thickness data and aquifer extent (see table 1).

${ }^{2}$ Values reported directly from cited reference; except where withdrawals by wells in 2003 are reported by the Minnesota Department of Natural Resources.

${ }^{3}$ Mean annual precipitation data from 2003 for county/area from www.climate.umn.edu.

${ }^{4}$ Values calculated (converted to similar units) from data reported in cited reference. 
Table 3. Nonsteady-state water budget for Buffalo aquifer in Red River of the North Basin, Minnesota, 1993.

[Values are percentage of known sources or losses of water. NA, not applicable]

\begin{tabular}{|c|c|c|}
\hline Component & $\begin{array}{c}\text { Ground-water } \\
\text { sources }\end{array}$ & $\begin{array}{c}\text { Ground- } \\
\text { water losses }\end{array}$ \\
\hline Net areal recharge (unconfined part) & 11 & NA \\
\hline Evapotranspiration & NA & $\begin{array}{l}\text { incorporated } \\
\text { in net } \\
\text { recharge }\end{array}$ \\
\hline Flow to (from) surface water & 89 & unknown \\
\hline Flow across boundaries & 0 & unknown \\
\hline Ground-water pumping & NA & $11(2003)$ \\
\hline Total & 100 & 11 \\
\hline
\end{tabular}

ground water was pumped from the aquifer at an almost constant mean rate of $386 \mathrm{Mgal} / \mathrm{yr}$ (Schoenberg, 1998). In 2003, ground-water pumping accounted for $408 \mathrm{Mgal} / \mathrm{yr}$ of discharge from the aquifer (Schoenberg, 1998), equivalent to 11 percent of the assumed total ground-water losses when losses equal inflows under steady-state conditions.

\section{Beach Ridge Aquifers}

Due to the variable grain size and sorting, geographic distribution, and hydraulic connectivity of the Beach Ridge aquifers throughout the Red River of the North Basin, the sources of ground-water recharge and discharge and a generalized water budget could not be determined.

\section{Middle River Surficial Aquifer}

Mean annual precipitation at Argyle, Minnesota, near the center of the Middle River surficial aquifer (fig. 4), was $19.06 \mathrm{in}$. (approximately 7,300 Mgal/yr) for a 42-year period (Maclay and others, 1965). Components of the aquifer's water budget were estimated by Maclay and others (1965) (tables 2 and 4) and are described in the following sections. The total flow of water through the ground-water system was estimated to be approximately 1,130 Mgal/yr (table 2) (Maclay and others, 1965).

\section{Sources of Water}

Net areal recharge and ground-water flow across the boundaries of the aquifer are the primary sources of water to the Middle River surficial aquifer (Maclay and others, 1965). Mean net areal recharge was estimated from the infiltration capacity of soils to be $3 \mathrm{in} / \mathrm{yr}$, accounting for 98 percent of the flow of water into the aquifer (table 4) (Maclay and others, 1965). On the basis of estimated transmissivity values, Maclay and others (1965) determined that ground-water flow to the
Table 4. Nonsteady-state water budget for Middle River surficial aquifer in Red River of the North Basin, Minnesota, 1962.

[Values are percentage of known sources or losses of water. NA, not applicable]

\begin{tabular}{lcc}
\hline \multicolumn{1}{c}{ Component } & $\begin{array}{c}\text { Ground-water } \\
\text { sources }\end{array}$ & $\begin{array}{c}\text { Ground-water } \\
\text { losses }\end{array}$ \\
\hline Net areal recharge & 98 & NA \\
Evapotranspiration & NA & $\begin{array}{c}\text { incorporated } \\
\text { in net } \\
\text { recharge } \\
\text { unknown }\end{array}$ \\
Flow to (from) surface water & unknown & unknown \\
Flow across boundaries & 2 & $2(2003)$ \\
Ground-water pumping & NA & \\
Total & & $\mathbf{2}$ \\
\hline
\end{tabular}

aquifer across its boundaries was approximately $30 \mathrm{Mgal} / \mathrm{yr}$ or 2 percent of the aquifer's total sources of water (table 4).

\section{Losses of Water}

Losses of water from the Middle River surficial aquifer occur by evapotranspiration of ground water, outflow across the aquifer's boundaries, flow to surface water, and withdrawals by pumping wells (Maclay and others, 1965). Although outflow across the boundaries and to surface water was not estimated, ground-water pumping from the aquifer totaled $26 \mathrm{Mgal} / \mathrm{yr}$ in 2003, accounting for approximately 2 percent of the aquifer's water-budget losses, which assumes steady-state conditions where losses equal sources (table 4).

\section{Two Rivers Surficial Aquifer}

On the basis of long-term climatic records, the mean annual precipitation was $20.07 \mathrm{in}$. in the area west of the Two Rivers surficial aquifer (Maclay and others, 1967), equivalent to $51,000 \mathrm{Mgal} / \mathrm{yr}$ across the extent of the aquifer. Nonsteadystate water-budget information for the aquifer was determined by Maclay and others $(1965,1967)$ (tables 2 and 5) and are described in the following sections. The total flow of water through the aquifer was estimated to be $6,500 \mathrm{Mgal} / \mathrm{yr}$ (table 2) (Maclay and others, 1965, 1967).

\section{Sources of Water}

Sources of water to the Two Rivers surficial aquifer are areal recharge and ground-water flow across boundaries of the aquifer from adjacent geologic units. On the basis of the infiltration capacity of soils, mean net areal recharge of the aquifer was estimated to be $2.5 \mathrm{in} / \mathrm{yr}(6,300 \mathrm{Mgal} / \mathrm{yr})$ in 1962 , accounting for 97 percent of the total water to the aquifer (table 5) (Maclay and others, 1965, 1967). Ground-water flow across the aquifer's boundaries was estimated to be about $200 \mathrm{Mgal} / \mathrm{yr}$ or 3 percent of the aquifer's sources of water (table 5) (Maclay and others, 1965, 1967). 
Table 5. Nonsteady-state water budget for Two Rivers surficial aquifer in Red River of the North Basin, Minnesota, 1962.

[Values are percentage of known sources or losses of water. NA, not applicable]

\begin{tabular}{|c|c|c|}
\hline Component & $\begin{array}{c}\text { Ground-water } \\
\text { sources }\end{array}$ & $\begin{array}{c}\text { Ground-water } \\
\text { losses }\end{array}$ \\
\hline Net areal recharge & 97 & NA \\
\hline Evapotranspiration & NA & $\begin{array}{l}\text { incorporated in net } \\
\text { recharge }\end{array}$ \\
\hline Flow to (from) surface water & unknown & unknown \\
\hline Flow across boundaries & 3 & unknown \\
\hline Ground-water pumping & NA & $7(2003)$ \\
\hline Total & 100 & 7 \\
\hline
\end{tabular}

Losses of Water

The primary losses of water from the aquifer are evapotranspiration, outflow across the aquifer's boundaries, flow to surface water, and withdrawal of ground water by wells. Ground-water withdrawals from the aquifer totaled $440 \mathrm{Mgal} / \mathrm{yr}$ in 2003 and represented 7 percent of the aquifer's total water losses which assumes steady-state conditions where losses equals sources (table 5).

\section{Pelican River Sand-Plain Aquifer}

Mean annual precipitation in the area of the Pelican River sand-plain aquifer is $23.57 \mathrm{in}$. (Miller, 1982). The long-term, mean annual amount of water lost to evapotranspiration was estimated to be $22.4 \mathrm{in}$. (Winter and others, 1969). Two detailed ground-water budgets for parts of the aquifer were developed by Miller (1982) using steady-state, ground-waterflow simulations. The two numerical models, referred to as the "Detroit Lakes model" and the "Scrambler model," were developed to simulate ground-water flow in the aquifer and to estimate the effects of hypothetical pumping. The simulations provided water-budget estimates (Miller, 1982) summarized in tables 2, 6, and 7 and described in the following sections. Total flow through the surficial aquifer was estimated by the simulations to range from 4,900 to 8,900 Mgal/yr (table 2) (Miller, 1982).

\section{Sources of Water}

Flow of water to the Pelican River sand-plain aquifer is the result of areal recharge, flow across the boundaries of the aquifer (from confining till units and semiconfined outwash that are buried by younger till), and flow from surface water (Miller, 1982). Mean net areal recharge to the aquifer, estimated from ground-water hydrographs by Miller (1982), was $4.9 \mathrm{in} / \mathrm{yr}$ in 1979 and $4.5 \mathrm{in} / \mathrm{yr}$ in 1980. However, inflow to the aquifer across its boundaries was negligible (Miller, 1982).

On the basis of the "Detroit Lakes model" simulation conducted by Miller (1982), sources of water to the surficial aquifer
Table 6. Steady-state simulated water budget from "Detroit Lakes model" (from Miller, 1982) for Pelican River sand-plain aquifer in Red River of the North Basin, Minnesota.

[Values are percentage of known sources or losses of water. NA, not applicable]

\begin{tabular}{lcc}
\hline \multicolumn{1}{c}{ Component } & $\begin{array}{c}\text { Ground-water } \\
\text { sources }\end{array}$ & $\begin{array}{c}\text { Ground-water } \\
\text { losses }\end{array}$ \\
\hline Net areal recharge & 62 & NA \\
Evapdotranspiration & NA & 56 \\
Flow to (from) surface water & 21 & 44 \\
Flow across boundaries & 17 & 0 \\
Ground-water pumping & NA & unknown \\
Total & & $\mathbf{1 0 0}$ \\
\hline
\end{tabular}

included areal recharge (62 percent of the total flow into the aquifer), ground-water flow across boundaries from adjacent geologic units (17 percent), and flow from surface water (21 percent) (table 6). Using the "Scrambler model" simulation, Miller (1982) determined that the total recharge to the area consisted of areal recharge (78 percent) and ground-water flow from surface water (22 percent) (table 7).

\section{Losses of Water}

On the basis of the "Detroit Lakes" simulation, total losses from the surficial aquifer consisted of evapotranspiration (56 percent) and flow to surface water (44 percent) (table 6 ) (Miller, 1982). Ground-water losses in the "Scrambler" simulation were estimated to be the result of ground-water evapotranspiration (39 percent), flow to surface water (59 percent), and outflow across the boundaries of the aquifer to adjacent geologic units (2 percent) (table 7) (Miller, 1982). Although ground water from the aquifer also is withdrawn by pumping wells (Miller, 1982), estimates were not included in the steadystate simulations.

Table 7. Steady-state simulated water budget from "Scrambler model" (from Miller, 1982) for Pelican River sand-plain aquifer in Red River of the North Basin, Minnesota.

[Values are percentage of known sources or losses of water. NA, not applicable]

\begin{tabular}{lcc}
\hline \multicolumn{1}{c}{ Component } & $\begin{array}{c}\text { Ground-water } \\
\text { sources }\end{array}$ & $\begin{array}{c}\text { Ground-water } \\
\text { losses }\end{array}$ \\
\hline Net areal recharge & 78 & NA \\
Evapotranspiration & NA & 39 \\
Flow to (from) surface water & 22 & 59 \\
Flow across boundaries & NA & 2 \\
Ground-water pumping & NA & unknown \\
Total & & \\
\hline
\end{tabular}




\section{Otter Tail Surficial Aquifer}

Mean annual precipitation in the area of the Otter Tail surficial aquifer was estimated to be 24 in. (Reeder, 1972). Water sources and losses for the aquifer's nonsteady-state water budget, described in the following sections, were determined by Reeder (1972) and are summarized in tables 2 and 8. On the basis of estimated values of water-budget components defined by Reeder (1972), the total flow through the aquifer was $51,000 \mathrm{Mgal} / \mathrm{yr}$ (table 2).

\section{Sources of Water}

On the basis of analyses of ground-water hydrographs, Reeder (1972) estimated that net areal recharge ranged from 5 to $6 \mathrm{in} / \mathrm{yr}$ across most of the Otter Tail surficial aquifer. However, mean net areal recharge ranged from 4 to $5 \mathrm{in} / \mathrm{yr}$ in parts of the aquifer near Perham and from 3 to $4 \mathrm{in} / \mathrm{yr}$ east and south of Battle Lake (fig. 7) (Reeder, 1972).

Net areal recharge (mean of $5.5 \mathrm{in} / \mathrm{yr}$ ) is the primary source of recharge to the surficial aquifer (Reeder, 1972), accounting for 96 percent of the aquifer's total recharge (table 8). Groundwater flow from adjacent aquifers (possibly the Pelican River sand-plain aquifer) into the northern part of the Otter Tail surficial aquifer northwest of Little Pine Lake (fig. 7) was estimated to be 4 percent of the total source of water to the aquifer (table 8) (Reeder, 1972). Although water from the Otter Tail River and numerous smaller streams, lakes, and wetlands recharges the surficial aquifer, the volume was not a substantial source (table 8) (Reeder, 1972).

\section{Losses of Water}

Water losses from the Otter Tail surficial aquifer are the result of evapotranspiration, outflow across the aquifer's boundaries, flow to rivers and streams, and ground water withdrawn by pumping wells (Reeder, 1972). Although estimates of flow to surface water and ground water discharged to wells were not available, ground-water flow to adjacent aquifers in the vicinity of the Otter Tail River at the southwest end of Otter Tail Lake

Table 8. Nonsteady-state water budget for Otter Tail surficial aquifer in Red River of the North Basin, Minnesota, 1969.

[Values are percentage of known sources or losses of water. NA, not applicable]

\begin{tabular}{lcc}
\hline \multicolumn{1}{c}{ Component } & $\begin{array}{c}\text { Ground-water } \\
\text { sources }\end{array}$ & $\begin{array}{c}\text { Ground-water } \\
\text { losses }\end{array}$ \\
\hline Net areal recharge & 96 & NA \\
Evapotranspiration & NA & $\begin{array}{c}\text { incorporated in net } \\
\text { recharge } \\
\text { unknown } \\
\text { Flow to (from) surface water }\end{array}$ \\
Flow across boundaries & 0 & 4 \\
Ground-water pumping & 4 & unknown \\
Total & NA & $\mathbf{4}$ \\
\hline
\end{tabular}

was estimated to be 2,000 Mgal/yr, accounting for 4 percent of the estimated water budget (table 8) (Reeder, 1972).

\section{Wadena Surficial Aquifer}

Mean annual precipitation in the Wadena area was estimated to be 26.4 in. on the basis of long-term climatic records from 1934 to 1967. Of this amount, $22.5 \mathrm{in} / \mathrm{yr}$ was estimated to be lost to evapotranspiration, and $3.9 \mathrm{in} / \mathrm{yr}$ was direct runoff to surface water (Lindholm, 1970). A detailed ground-water budget for the Wadena area, including the confined and surficial aquifers, was developed by Lindgren (2002) using a steadystate ground-water-flow simulation. An estimate of the water budget for the Wadena surficial aquifer from Lindgren's study is summarized in tables 2 and 9 and described in the following sections. Total flow through the surficial aquifer was estimated to be $92,000 \mathrm{Mgal} / \mathrm{yr}$ on the basis of model simulations (table 2) (Lindgren, 2002).

\section{Sources of Water}

The analyses of ground-water hydrographs by Lindholm (1970) determined that the mean net areal recharge to the aquifer was estimated to be 8 in. in 1967. Lindgren (2002) estimated that the net areal recharge to the aquifer ranged from $11.5 \mathrm{in} / \mathrm{yr}$ in 1999 to $13.9 \mathrm{in} / \mathrm{yr}$ in 1998 on the basis of monthly groundwater-level measurements from 17 observation wells completed within the unconfined part of the aquifer. Slightly greater net areal recharge was estimated from wells in the Leaf River area of the aquifer in 1998-99, ranging from 10.6 to $23 \mathrm{in} / \mathrm{yr}$, with a mean of $15.5 \mathrm{in} / \mathrm{yr}$ (Lindgren, 2002).

A simulated water budget for the Wadena area, including the confined and surficial aquifers, was developed by Lindgren (2002) to estimate sources of recharge and discharge to the confined/surficial aquifer system. Recharge to the Wadena surficial aquifer occurred by areal recharge and by flow from surface water and a confining unit (Lindgren, 2002). Areal recharge of the aquifer accounted for 73 percent of the total flow of water to the aquifer, flow across the aquifer's boundaries

Table 9. Steady-state simulated water budget for Wadena surficial aquifer in Red River of the North Basin, Minnesota.

[Values are percentage of known sources or losses of water. NA, not applicable]

\begin{tabular}{lcc}
\hline \multicolumn{1}{c}{ Component } & $\begin{array}{c}\text { Ground-water } \\
\text { sources }\end{array}$ & $\begin{array}{c}\text { Ground-water } \\
\text { losses }\end{array}$ \\
\hline Net areal recharge & 73 & NA \\
Evapotranspiration & NA & 35 \\
Flow to (from) surface water & 1 & 46 \\
Flow across boundaries & 26 & 17 \\
Ground-water pumping & NA & 2 \\
& & $\mathbf{1 0 0}$ \\
\hline
\end{tabular}


(from the confining unit) was 26 percent, and ground-water flow from surface water was estimated to be 1 percent (table 9) (Lindgren, 2002).

\section{Losses of Water}

Steady-state simulations conducted by Lindholm (2002) indicated that ground-water flow from the Wadena surficial aquifer to lakes and streams was 46 percent of the total losses. Evapotranspiration from ground water accounted for 35 percent of the total losses, ground-water outflow across the boundaries of the aquifer was 17 percent, and ground water discharged to wells was 2 percent of total losses (table 9) (Lindgren, 2002).

\section{Pineland Sands Surficial Aquifer}

The long-term, mean rate of evapotranspiration during May through October was estimated to be $22 \mathrm{in}$. in the area of the Pinelands Sands surficial aquifer. However, if all of the mean precipitation in the area (19 in/yr) is lost to evapotranspiration, the maximum rate of evapotranspiration of ground water directly from the aquifer is $3 \mathrm{in} / \mathrm{yr}$ (Helgesen, 1977). A steadystate simulation of the Pineland Sands surficial aquifer, developed by Helgesen (1977), estimated that total flow through the surficial aquifer was 70,000 Mgal/yr (tables 2 and 10). An estimation of the water budget for the aquifer made on the basis of that study is summarized in tables 2 and 10 and described in the following sections.

\section{Sources of Water}

Net areal recharge to the Pineland Sands surficial aquifer was estimated by Helgesen (1977) from ground-water-level records for 33 wells in 1975-76 and for one well in 1971-76 to be $5.1 \mathrm{in} / \mathrm{yr}$. However, stream base-flow data collected from the Straight River Basin area (fig. 9) in 1988 indicated that net areal recharge was more than $12 \mathrm{in} / \mathrm{yr}$ and was substantially greater than estimates of areal recharge in other sand-plain areas of Minnesota (Stark and others, 1994), including those for the Pineland Sands surficial aquifer (Helgesen, 1977).

Table 10. Steady-state simulated water budget for Pineland Sands surficial aquifer in Red River of the North Basin, Minnesota.

[Values are percentage of known sources or losses of water. NA, not applicable]

\begin{tabular}{lcc}
\hline \multicolumn{1}{c}{ Component } & $\begin{array}{c}\text { Ground-water } \\
\text { sources }\end{array}$ & $\begin{array}{c}\text { Ground-water } \\
\text { losses }\end{array}$ \\
\hline Net areal recharge & 83 & NA \\
Evapotranspiration & NA & 7 \\
Flow to (from) surface water & 8.5 & 93 \\
Flow across boundaries & 8.5 & NA \\
Ground-water pumping & NA & NA \\
Total & & $\mathbf{1 0 0}$ \\
\hline
\end{tabular}

Steady-state simulations conducted by Helgesen (1977) estimated that areal recharge was 83 percent of the total inflow of water to the aquifer. Flow across the aquifer's boundaries from adjacent aquifers was 8.5 percent, and flow from surface water was estimated to be 8.5 percent of the total recharge (table 10) (Helgesen, 1977).

\section{Losses of Water}

Under steady-state conditions and no withdrawal of ground water by pumping wells, 93 percent of the aquifer's discharge was to surface water, and loss of ground water from evapotranspiration was 7 percent of the total discharge (table 10) (Helgesen, 1977). However, minor to moderate losses of ground-water storage and decreases in surface-water elevations were predicted by increasing simulated pumping rates from 780 to $28,300 \mathrm{Mgal} / \mathrm{yr}$ in three alternate water-budget estimates (Helgesen, 1977).

\section{Bemidji-Bagley Surficial Aquifer}

Total annual precipitation in the Bemidji-Bagley area ranges from 24 to 26 in. (Baker and Kuehnast, 1978). Of this amount, the potential evapotranspiration was estimated to be $22 \mathrm{in} / \mathrm{yr}$, and annual runoff was approximately $2 \mathrm{in.} \mathrm{(Baker} \mathrm{and}$ others, 1979).

Regional ground-water flow simulations were developed by Stark and others (1991) to evaluate flow in the confined and surficial Bemidji-Bagley aquifers (a total area of 1,050 $\mathrm{mi}^{2}$ ) and to determine a hypothetical, steady-state water budget for the regional aquifer system. On the basis of these simulations, recharge to the regional aquifer system consisted of net areal recharge (95 percent) and flow from surface water ( 5 percent). Discharge from the regional system consisted of flow to surface water (99 percent) and ground water withdrawn by wells (1 percent) (Stark and others, 1991). The simulations indicated that the confined aquifer was a substantial component of the regional ground-water system and that ground-water flow in the surficial aquifer was not able to be represented with precision due to its discontinuity and thinness, suggesting that it constituted only a minor part of the regional system (Stark and others, 1991).

A nonsteady-state water budget for the Bemidji-Bagley surficial aquifer, summarized in tables 2 and 11 and described in the following sections, was estimated by Stark and others (1991). The total flow through the surficial aquifer was estimated to be about 44,000 Mgal/yr (table 2)

\section{Sources of Water}

Inflow of water to the unconfined Bemidji-Bagley surficial aquifer is primarily by direct areal recharge. On the basis of hydrograph analysis of an observation well completed in the surficial aquifer, the mean net areal recharge was estimated to be $4 \mathrm{in} / \mathrm{yr}$ in 1986-87; equivalent to 44,000 Mgal/yr (table 11) (Stark and others, 1991). The estimated areal recharge rate is 
Table 11. Nonsteady-state water budget for Bemidji-Bagley surficial aquifer in Red River of the North Basin, Minnesota, 1986-87.

[Values are percentage of known sources or losses of water. NA, not applicable]

\begin{tabular}{|c|c|c|}
\hline Component & $\begin{array}{c}\text { Ground-water } \\
\text { sources }\end{array}$ & $\begin{array}{c}\text { Ground-water } \\
\text { losses }\end{array}$ \\
\hline Net areal recharge & 100 & NA \\
\hline Evapotranspiration & NA & $\begin{array}{c}\text { incorporated in } \\
\text { net recharge }\end{array}$ \\
\hline Flow to (from) surface water & unknown & unknown \\
\hline Flow across boundaries & unknown & unknown \\
\hline Ground-water pumping & NA & unknown \\
\hline Total & 100 & $\mathbf{0}$ \\
\hline
\end{tabular}

consistent with recharge rates estimated $50 \mathrm{mi}$ to the south (Helgesen, 1977) and similar to rates (4 to $8 \mathrm{in} / \mathrm{yr}$ ) that produced the best matches between simulated and measured groundwater levels in the aquifer (Stark and others, 1991). Although less substantial, areal recharge of the surficial aquifer also occurs through the overlying glacial till located at land surface. However, the rate of recharge through the till to the aquifer is dependent on the glacial source and texture of the till and ranged from 0 to $8 \mathrm{in} / \mathrm{yr}$ (Stark and others, 1991).

\section{Losses of Water}

Ground-water losses from the aquifer consist of flow to surface water, evapotranspiration, and ground-water withdrawal by wells (Stark and others, 1991). Although flow from the aquifer to rivers and streams, estimated in 1988 by measuring base flow in local rivers and their tributaries, was generally greater than recharge from surface water, the flow of water lost to surface water is unknown (table 11) (Stark and others, 1991). Ground-water losses to evapotranspiration are probably the most substantial in the eastern part of the aquifer where many surface-water bodies are located (fig. 10) and ground water is relatively shallow. Although withdrawals of ground water from the confined and surficial aquifers of the Bemidji-Bagley area by public, private, and irrigation wells were reported in 1985 , the volumes were not specific to withdrawals from the surficial aquifer (table 11) and represent only a minor percentage of the total losses from the aquifer (Stark and others, 1991).

\section{Estimates of Maximum Aquifer Volume}

Ground-water storage in five of the surficial aquifers (Pelican River sand-plain aquifer and Otter Tail, Wadena, Pinelands Sands, and Bemidji-Bagley surficial aquifers) was estimated using published areal extent, saturated thickness, and porosity data. The volume of water stored in the Two Rivers surficial aquifer was estimated by prorating the volume of ground water stored in a $24-\mathrm{mi}^{2}$ area of the aquifer (Schiner, 1963) to the most recently determined aquifer area $\left(146 \mathrm{mi}^{2}\right)$. Because the storage volumes are approximations for each of the aquifers, the values do not represent the actual volume of ground water that is available from the aquifers. In this study, the storage estimates represent the maximum volume of ground water the aquifers are capable of storing.

The total volume of ground water capable of being stored in eight of the surficial aquifers, excluding the Beach Ridge aquifers, was estimated to be approximately $2,875 \mathrm{bgal}$ (table 1). The maximum volume of water stored in the individual aquifers was estimated to range from $4.6 \mathrm{bgal}$ in the Middle River surficial aquifer (Maclay and others, 1965) to 1,000 bgal in the Pineland Sands surficial aquifer, accounting for approximately 35 percent of the total volume of potential ground water (table 1). The Otter Tail and Two Rivers surficial aquifers are capable of containing the second and third largest volumes of ground water, respectively, accounting for approximately 17 and 14 percent of the total maximum volume of stored ground water in the study area. Although Wolf (1981) estimated that the Buffalo aquifer had a storage volume of $270 \mathrm{bgal}$ (table 1), only 120 bgal could be withdrawn from the aquifer. Maximum volumes of ground water stored in the surficial aquifers are summarized in table 1.

\section{Theoretical Well Yields and Ground-Water Pumping Tests and Simulations}

In general, maximum well yields from the nine surficial aquifers occur in those parts of the aquifers with more abundant, well-sorted, coarse-grained sediment. Conversely, the smallest theoretical yields generally occur along the outermost margins of the aquifers where the deposits are thinnest and transmissivity and (or) hydraulic conductivity values and saturated thickness are smallest. Areas of the surficial aquifers that produced the largest theoretical well yields are limited in size and likely would not support long-term, high rates of ground-water pumping. Theoretical well yields from the nine surficial aquifers were compiled from published aquifer studies and are summarized in table 1.

\section{Buffalo Aquifer}

In the Buffalo aquifer, the largest well yields generally were located along the deep, narrow trough of the north-south trending axis of the aquifer (Wolf, 1981). The maximum estimated well yield from the Buffalo aquifer (as great as $10,000 \mathrm{gal} / \mathrm{min}$; Wolf, 1981) was the largest theoretical yield determined for the nine aquifers in the study area (table 1).

In 1993, Schoenberg (1998) conducted an aquifer test in the northern part of the Buffalo aquifer in which one pumping well and three observation wells were used. Following 10 days of pumping at a rate of $1,090 \mathrm{gal} / \mathrm{min}(573 \mathrm{Mgal} / \mathrm{yr})$, the well was allowed to recover for 20 days. Following recovery, ground-water levels at two observation wells indicated no response to the pumping (Schoenberg, 1998). However, an 
increase in the ground-water pumping rate from approximately $320 \mathrm{Mgal} / \mathrm{yr}$ in $1970-89$ to as much as $720 \mathrm{Mgal} / \mathrm{yr}$ in $1988-89$ resulted in a decline of the aquifer's water level by about $10 \mathrm{ft}$ at one observation well (Schoenberg, 1998).

\section{Beach Ridge Aquifers}

Theoretical well yields from the Beach Ridge aquifers generally range from 10 to $500 \mathrm{gal} / \mathrm{min}$ (Stoner and others, 1993). However due to their variable texture, distribution, and hydraulic properties across the Red River of the North Basin, well yields from the Beach Ridge aquifers are likely to be unpredictable and inconsistent.

\section{Middle River Surficial Aquifer}

Well yields from the Middle River surficial aquifer, ranging from $5 \mathrm{gal} / \mathrm{min}$ (in the eastern part) to more than $50 \mathrm{gal} / \mathrm{min}$ (from the thickest sections of the central and northwest parts of the aquifer) (fig. 4) (table 1) (Maclay and others, 1965), are the smallest theoretical yields known within the study area.

\section{Two Rivers Surficial Aquifer}

The largest potential well yields (more than 1,000 gal $/ \mathrm{min}$; table 1) from the Two Rivers surficial aquifer are near Lake Bronson (fig. 5) where surface water recharges the aquifer and the saturated thickness of coarse-grained sand and gravel is greater than $150 \mathrm{ft}$ (Maclay and others, 1967). Well yields of 50 to more than $100 \mathrm{gal} / \mathrm{min}$ potentially could be developed from the sand-rich part of the aquifer near Lancaster, Minnesota (fig. 5) (Maclay and others, 1967).

\section{Pelican River Sand-Plain Aquifer}

Maximum well yields from the Pelican River sand-plain aquifer were estimated to be as much as $1,200 \mathrm{gal} / \mathrm{min}$ (table 1) in areas southeast of Detroit Lake, west of Lake Melissa, west of Pelican Lake, west-southwest of Big Cormorant Lake, and from Prairie Lake to southwest of Pelican Rapids, Minnesota (fig. 6) (Miller, 1982).

Aquifer-testing of the Pelican River sand-plain aquifer conducted by Miller (1982) indicated that pumping from one local confined aquifer had no effect on ground-water levels in the unconfined part of the Pelican River sand-plain aquifer. However, analytical simulations suggested that the surficial aquifer was hydraulically connected to local surface-water bodies. It was demonstrated that near the Pelican River (fig. 6) pumping wells could induce substantial amounts of recharge to the surficial aquifer from the river and that aquifer recharge was dependent on the number of pumping wells, pumping rates, duration of pumping, and distance of the pumping wells from the river (Miller, 1982).
Steady-state numerical ground-water pumping simulations conducted by Miller (1982) showed that drawdown of the water table would be greatest in the northern one-half of the aquifer. Under normal recharge conditions, a 3-month, long-term pumping period, and constant, maximum theoretical well yields ranging from 300 to $1,200 \mathrm{gal} / \mathrm{min}$, drawdown of the water table in the northern part of the aquifer was estimated between 2 and $8 \mathrm{ft}$ (Miller, 1982). In simulations that reduced aquifer recharge to one-half that of normal conditions, drawdown of the local water table more than doubled in some areas to as much as 10 to $25 \mathrm{ft}$ below normal ground-water levels. However, only minor (less than $5 \mathrm{ft}$ ) drawdown of the water table was estimated in the southern part of the aquifer near Prairie Lake (fig. 6) (Miller, 1982).

The direct correlation between simulated ground-water pumping and water-table altitudes conducted by Miller (1982) demonstrated the sensitivity of the Pelican River sand-plain aquifer to increased ground-water withdrawals. Assuming normal recharge of the aquifer, long-term, steady-state groundwater pumping similar to rates simulated by Miller (1982) would likely produce minimal and acceptable drawdown of the local water table and surface water. However, during sustained periods of below-normal precipitation and aquifer recharge, and (or) increased withdrawal of ground water, it is expected that drawdown of the water table would affect surface-water elevations and the availability of ground water (Miller, 1982).

\section{Otter Tail Surficial Aquifer}

Theoretical well yields in the Otter Tail surficial aquifer were similar to those from the Pelican River sand-plain aquifer and varied over relatively short distances (Reeder, 1972). Maximum well yields ranging from 1,200 to $1,500 \mathrm{gal} / \mathrm{min}$ (Anderson, 1980) were the third largest of the nine aquifers located in the study area (table 1).

\section{Wadena Surficial Aquifer}

In 10 percent of the Wadena surficial aquifer in locations west, southeast, and south-southeast of Wadena, Minnesota, and along the Leaf River (fig. 8), maximum theoretical well yields were estimated to be more than $900 \mathrm{gal} / \mathrm{min}$. Yields of more than $300 \mathrm{gal} / \mathrm{min}$ could be produced from single wells in 60 percent of the aquifer's extent, and less than $100 \mathrm{gal} / \mathrm{min}$ were estimated for 15 percent of aquifer in the eastern and southeastern parts (Lindholm, 1970).

Ground-water development simulations were used by Lindholm (1970) to determine the greatest potential pumping rate that the Wadena surficial aquifer could sustain. The results of the simulations suggested that regional drawdown of the water table reached equilibrium each year during a recovery period prior to the next pumping cycle. On the basis of results from the simulations, $7.5 \mathrm{bgal} / \mathrm{yr}$ of water could be withdrawn consistently from the aquifer without substantially decreasing the water table (Lindholm, 1970). However, increased 
pumping, even at less-than-maximum hypothetical rates, likely would cause local tributary streams to become dry and would substantially decrease flows in larger perennial streams such as the Leaf and Crow Wing Rivers (fig. 8). Results of the simulations also indicated that continued maximum pumping from the aquifer likely would decrease water-table altitudes and the saturated thickness of the surficial aquifer (Lindholm, 1970).

The steady-state ground-water flow simulations developed by Lindgren (2002) were used to evaluate the availability of ground water in the Wadena area by assessing the potential effects of hypothetical conditions on ground-water levels and streamflow. Results of the simulations indicate that historical pumping has lowered the regional water table of the surficial aquifer by an average of $0.31 \mathrm{ft}$, with the greatest decline occurring near Wadena (4.0 ft) and Staples (2.5 ft), Minnesota (fig. 8) (Lindgren, 2002). Ground water discharged to rivers and streams was reduced by less than 1 percent relative to predevelopment levels as a result of pumping (Lindgren, 2002). The simulations suggested that estimated increases in pumping rates may only have minor effects on ground-water levels and streamflow in the area. Assuming the projected increase in pumping, additional regional drawdown of the Wadena surficial aquifer was estimated to average $0.03 \mathrm{ft}$, with maximum declines of $0.3 \mathrm{ft}$ near Wadena, Minnesota, and streamflow was estimated to only decrease by approximately 0.6 percent of 1998-99 levels, with minor decreases in ground-water evapotranspiration (Lindgren, 2002).

The results of Lindgren's (2002) steady-state ground-water flow simulations also indicated that anticipated increases in ground-water withdrawal rates during drought periods may decrease regional ground-water levels by 2 to $4 \mathrm{ft}$ within the surficial and confined parts of the Wadena aquifer and reduce ground-water discharge to rivers and streams by as much as 23 percent relative to conditions in 1998-99. Localized decreases in the surficial aquifer's water table could be as great as $6 \mathrm{ft}$ near Wadena, Minnesota (fig. 8), and the central part of the aquifer (Lindgren, 2002). However, during periods of normal precipitation (and aquifer recharge) and increased groundwater pumping, the simulations suggested only minimal effects on ground-water levels and streamflow (Lindgren, 2002).

\section{Pineland Sands Surficial Aquifer}

Maximum theoretical well yields, estimated to range from 2,000 to $4,000 \mathrm{gal} / \mathrm{min}$ in isolated parts of the Pineland Sands surficial aquifer (table 1) (Helgesen, 1977), were the second largest estimated yields from the nine surficial aquifers. Single well yields of $500 \mathrm{gal} / \mathrm{min}$ were obtainable throughout most of the aquifer, and yields of at least $1,000 \mathrm{gal} / \mathrm{min}$ were determined for 15 percent of its extent. However, well yields less than $100 \mathrm{gal} / \mathrm{min}$ were estimated for 30 percent of the aquifer (Helgesen, 1977).

Ground-water numerical simulation analyses by Helgesen (1977) demonstrated that much of the Pineland Sands surficial aquifer could support long-term, large-scale withdrawals. The results showed that ground-water withdrawals of about $780 \mathrm{Mgal} / \mathrm{yr}$ did not substantially affect the aquifer. The simulations indicated that ground-water withdrawals of 14,000 and $28,000 \mathrm{Mgal} / \mathrm{yr}$ resulted in substantial declines in the water table, as much as $12 \mathrm{ft}$ at some locations, and likely would result in decreased streamflow and lower lake elevations in areas of intensive ground-water development (Helgesen, 1977).

On the basis of the ground-water simulations conducted by Helgesen (1977), long-term withdrawal rates similar to those in 2003 (8,179 Mgal/yr; table 12) are likely to affect the availability of ground water in localized areas of the aquifer. Although the withdrawal rate of water from the aquifer in 2003 was less than the simulated withdrawals calculated by Helgesen (1977), the 2003 pumping data do not include withdrawals from private supply wells. The 2003 pumping data also demonstrate the increase in development of the aquifer from 1977 (780 Mgal/yr; Helgesen, 1977) to 2003. Continued development of the Pineland Sands surficial aquifer at rates similar to the recently observed trend of ground-water withdrawals likely will result in substantial declines of water-table altitudes and aquifer saturated thickness, resulting in varying ground-water quality and reductions in surface-water elevations and streamflow.

\section{Bemidji-Bagley Surficial Aquifer}

Well yields of several hundred gallons per minute are achievable in isolated parts of the Bemidji-Bagley surficial aquifer. In general, well yields in the aquifer range from 10 to $300 \mathrm{gal} / \mathrm{min}$ (table 1) (Stark and others, 1991). However, the discontinuity of the saturated parts of the aquifer (fig. 10) and its thinness limit the potential productivity of the aquifer (Stark and others, 1991). Although hydraulic conductivity estimates for the aquifer are relatively large, transmissivity and theoretical well yields are small because large areas of the aquifer are thinly saturated or completely unsaturated (fig. 10). Therefore, the availability of ground water across the extent of the aquifer may not be consistent.

\section{Recent Ground-Water Withdrawals and Uses}

In 2003, approximately 28 bgal of ground water were withdrawn from eight surficial aquifers (excluding the Beach Ridge aquifers) in the Minnesota part of the Red River of the North Basin, not including water used for private supply (table 12) (Minnesota Department of Natural Resources, written commun., 2004). Withdrawals from the Otter Tail surficial aquifer were the most, totaling 9,173 Mgal, and ground water withdrawn from the Otter Tail, Pineland Sands, and Wadena surficial aquifers totaled 87 percent of the ground-water resources withdrawn in 2003. Water withdrawn from the Middle River surficial aquifer (26 Mgal) accounted for the smallest volume withdrawn from the eight surficial aquifers (Minnesota Department of Natural Resources, written commun., 2004). The volumes of ground water withdrawn from the aquifers in 2003 and the uses of the water are summarized in table 12 . 
Table 12. Ground-water withdrawals from selected surficial aquifers in Red River of the North Basin, Minnesota, $2003^{1}$.

[Ground-water withdrawals obtained from the Minnesota Department of Natural Resources (written commun., 2004). Mgal, millions of gallons; --, data not available]

\begin{tabular}{|c|c|c|c|c|c|c|c|c|c|c|c|}
\hline \multirow[b]{2}{*}{ Aquifer name } & \multicolumn{9}{|c|}{ Water use } & \multirow{2}{*}{$\begin{array}{c}\text { Total water } \\
\text { withdrawals } \\
\text { by aquifer } \\
\text { (Mgal) }\end{array}$} & \multirow{2}{*}{$\begin{array}{l}\text { Percentage of } \\
\text { total } \\
\text { withdrawals } \\
\text { from eight } \\
\text { surficial } \\
\text { aquifers by } \\
\text { aquifer }\end{array}$} \\
\hline & $\begin{array}{l}\text { Aquacul- } \\
\text { ture } \\
\text { (Mgal) }\end{array}$ & $\begin{array}{l}\text { Commer- } \\
\text { cial } \\
\text { (Mgal) }\end{array}$ & $\begin{array}{c}\text { Golf } \\
\text { irrigation } \\
\text { (Mgal) }\end{array}$ & $\begin{array}{c}\text { Industrial } \\
\text { (Mgal) }\end{array}$ & $\begin{array}{l}\text { Agricul- } \\
\text { tural } \\
\text { irrigation } \\
\text { (Mgal) }\end{array}$ & $\begin{array}{l}\text { Livestock } \\
\text { (Mgal) }\end{array}$ & $\begin{array}{l}\text { Mining } \\
\text { (Mgal) }\end{array}$ & $\begin{array}{l}\text { Public } \\
\text { supply } \\
\text { (Mgal) }\end{array}$ & $\begin{array}{c}\text { Thermo- } \\
\text { electric } \\
\text { (Mgal) }\end{array}$ & & \\
\hline Buffalo aquifer & -- & -- & -- & -- & 334.6 & -- & -- & 73.3 & -- & 408 & 1.5 \\
\hline Beach Ridge aquifers & -- & -- & -- & -- & -- & -- & -- & -- & -- & -- & -- \\
\hline Middle River surficial aquifer & -- & -- & -- & -- & -- & -- & -- & 25.8 & -- & 26 & .1 \\
\hline Two Rivers surficial aquifer & -- & -- & -- & -- & 261.4 & -- & 21.1 & 156.2 & -- & 440 & 1.6 \\
\hline Pelican River sand-plain aqufier & 1.0 & 3.5 & 93.6 & -- & 989.5 & -- & 67.8 & 716.9 & -- & 1,872 & 6.7 \\
\hline Otter Tail surficial aquifer & -- & 49.1 & 131.5 & 12.9 & 8,556 & 6.3 & -- & 417.2 & -- & 9,173 & 32.9 \\
\hline Wadena surficial aquifer & 10.2 & -- & 28.5 & -- & 6,473 & -- & -- & 289.6 & -- & 6,802 & 24.4 \\
\hline Pineland Sands surficial aquifer & -- & -- & 78.9 & 556.2 & 7,211 & -- & 21.0 & 312.4 & -- & 8,179 & 29.3 \\
\hline Bemidji-Bagley surficial aquifer & 2.8 & 72.0 & 46.4 & 48.3 & 49.5 & -- & -- & 691.9 & 82.9 & 994 & 3.6 \\
\hline Total water withdrawals by type & 14.0 & 124.6 & 378.9 & 617.4 & 23,880 & 6.3 & 109.9 & 2,683 & 82.9 & 27,900 & \\
\hline Percentage of total withdrawals by type & .05 & .4 & 1.4 & 2.2 & 85.6 & .02 & .4 & 9.6 & .3 & & \\
\hline
\end{tabular}

${ }^{1} 2003$ ground-water withdrawal data do not include withdrawals for private domestic (self-supply) use. 


\section{Ground-Water Availability from Surficial Aquifers in the Red River of the North Basin, Minnesota}

The pumping data from 2003 indicate that ground water withdrawn for agricultural irrigation and golf irrigation totaled 87 percent of all ground water withdrawn from the study area (table 12) (Minnesota Department of Natural Resources, written commun., 2004). Public supply (9.6 percent) was the second greatest use of ground water in 2003. Other uses of ground water pumped from the aquifers, in order by the volume withdrawn, included industrial, commercial, mining, thermoelectric energy, aquaculture, and livestock (table 12) (Minnesota Department of Natural Resources, written commun., 2004).

Water from the Buffalo aquifer is used for municipal and domestic supplies, and agricultural processing and irrigation (Schoenberg, 1998). The aquifer is the primary water source for the towns of Glyndon and Sabin, Minnesota (fig. 3), and a secondary source of water for the city of Moorhead, Minnesota (fig. 3) (Minnesota Department of Natural Resources, 2000). In 2003, excluding water withdrawn for private supply, $408 \mathrm{Mgal}$ of ground water were removed from the aquifer (table 12). Eighty-two percent of the ground water was used for agricultural irrigation in 2003. Relative to ground-water withdrawal rates from the Buffalo aquifer in 1988-89 (720 Mgal/yr) that produced marked declines in water-table levels (Schoenberg, 1998), the 2003 pumping rate is likely to create minimal to moderate drawdown. Ground-water withdrawals for 2003 from the Buffalo aquifer are summarized in table 12.

Although the municipal water supply wells for Crookston, Minnesota, are located within the Beach Ridge aquifers, ground water from the deposits is used more commonly for private water supply (T.K. Cowdery, U.S. Geological Survey, oral commun., 2004). The quantity of usable ground water in the Beach Ridge aquifers generally increases to the south where the deposits are closer together and often contiguous with one another and, therefore, able to store larger volumes of ground water. In addition to providing local private water supply, the beach ridge deposits commonly are used for sand-and-gravel mining operations (T.K. Cowdery, U.S. Geological Survey, oral commun., 2004). Due to the variable distribution and nonuniform aquifer characteristics of the Beach Ridge aquifers, storage volumes and uses of ground water in 2003 could not be estimated.

Ground water from the Middle River surficial aquifer is used for public supply, industrial, commercial, and agricultural purposes (Maclay and others, 1965). In 1965, ground-water use totaled $12.5 \mathrm{Mgal} / \mathrm{yr}$, including domestic and municipal supply, industrial and commercial uses, and agricultural activities (Maclay and others, 1965). On the basis of estimated recharge to the aquifer, more than twice the 1965 annual pumping rate could be developed without a substantial decline in the water table (Maclay and others, 1965). In 2003, about $26 \mathrm{Mgal}$ of withdrawals were reported from the aquifer, all of which were used for public supply (table 12). Due to its substantial saturated thickness, the most favorable area of the aquifer for development is the central part, east of Argyle, Minnesota (fig. 4) (Maclay and others, 1965). It was estimated by Maclay and others (1965) that the aquifer may be capable of storing 4.6 bgal of water (table 1); however, only a small part of that volume was economically viable. Ground-water withdrawals from the aquifer are summarized in table 12 .

The Two Rivers surficial aquifer is the largest potential source of ground water within the Middle River and Two Rivers watersheds (Maclay and others, 1965, 1967). Although the surficial aquifer could be capable of providing substantial ground-water resources in the area, it was estimated that Lake Bronson contains 1.2 bgal of water and could provide considerable water supply (Maclay and others, 1965, 1967). In 1967, it was estimated that 1.1 Mgal of ground water were used within the northern two-thirds of the aquifer (Maclay and others, 1967), and in 1965, approximately 3.1 Mgal were withdrawn from the southern part for domestic and municipal supplies and agricultural use (Maclay and others, 1965). In 2003, the volume of ground water withdrawn (440 Mgal) was more than 100 times greater than withdrawals for 1965 and 1967. Ground-water withdrawals from the aquifer in 2003 are summarized in table 12.

Ground water from the Pelican River sand-plain aquifer is suitable for irrigation, municipal, and other uses (Anderson, 1980). In 2003, the primary uses of water withdrawn from the aquifer were agricultural irrigation (53 percent) and public supply (38 percent) (table 12). Fifty-nine percent of all ground water withdrawn from the aquifer in 1976 was used for agricultural and golf course irrigation (Anderson, 1980). Groundwater withdrawals in 2003 are summarized in table 12.

Agricultural irrigation was the primary use (93 percent) of water from the Otter Tail surficial aquifer in 2003 (table 12). During 1976, irrigation was the largest use of ground water in Becker and Otter Tail Counties, accounting for 64 percent of the total ground water withdrawn. Municipal use of ground water accounted for 12 percent in 1976, a part of which was from bedrock or buried outwash aquifers (Anderson, 1980). Although the Otter Tail surficial aquifer is a substantial source of ground water, depending on the location of pumping centers, increased development may cause declines in local lake elevations, streamflow, and the aquifer water table and saturated thickness, and may result in changes in ground-water quality. Groundwater withdrawals from the aquifer in 2003 are summarized in table 12.

Not including water withdrawn by private water-supply wells, 6,802 Mgal of ground water were pumped from the Wadena surficial aquifer in 2003 (table 12). Agricultural irrigation accounted for 95 percent of the total volume of ground water withdrawn from the aquifer. Ground-water withdrawals from the aquifer totaled 1.2 bgal in 1997 and increased approximately 63 percent in 1998 to 1.9 bgal (Lindgren, 2002). During 1997 and 1998, the volume of water pumped from irrigation, municipal, and commercial wells within the aquifer totaled 72 and 77 percent of total withdrawals, respectively (Lindgren, 2002).

Ground water from the Pineland Sands surficial aquifer is acceptable for irrigation purposes (Helgesen, 1977), and water from the part of the aquifer located in the Straight River Basin area (fig. 9) is suitable for aquatic life, agriculture, wildlife, and 
domestic consumption (Stark and others, 1994). The total volume of ground water pumped from the aquifer in 2003, excluding water withdrawn by private supply wells, was 8,179 Mgal. The primary uses of ground water pumped from the aquifer were agricultural irrigation (88 percent) and industrial ( 7 percent) (table 12). Ground-water withdrawals from the aquifer in 2003 are summarized in table 12.

The main use of ground water during 1985 from the Bemidji-Bagley area (from the unconfined and uppermostconfined aquifers) was for municipal (Bemidji, Bagley, and Cass Lake, Minnesota) (fig. 10) and private water supply, and for agricultural irrigation (Stark and others, 1991). During 2003 , the primary use of ground water from the Bemidji-Bagley surficial aquifer was for public supply, totaling 70 percent of the ground-water withdrawals (table 12). Ground-water withdrawals from the aquifer in 2003 are summarized in table 12 .

\section{Ground-Water Quality}

Concentrations of selected constituents in samples from the surficial aquifers in the study area were compiled from previous studies and are summarized in table 13 and illustrated in figure 12. Sufficient ground-water-quality data were not available for evaluation in this report from the Beach Ridge aquifers and Middle River (excluding chloride data) and Two Rivers surficial aquifers. Maximum, minimum, and median concentrations for selected constituents in the aquifers also were compared to median concentrations (when available) of samples collected for the Red River of the North National Water-Quality Assessment (NAWQA) study conducted by USGS and reported by Cowdery (1998). Samples for the NAWQA study were collected from surficial aquifers located within two of the physiographic areas (Red River Valley Lake Plain and Moraine) located in the Minnesota part of the basin (Cowdery, 1998).

Because the water-quality data were compiled from numerous, individual studies, the laboratory reporting limits for the data were different. In addition, concentrations of zero (0) were reported in many of the previous aquifer studies but could not be accurately displayed on the logarithmic scales in figure 12. To represent the various reporting limits and the zero-value data as accurately as possible, current laboratory reporting limits $(0.06 \mu \mathrm{g} / \mathrm{L}, 2002$, and $0.006 \mathrm{mg} / \mathrm{L}, 2004)$ are included on the nitrate (as nitrogen) and iron plots, respectively, in figure 12.

Water samples from the surficial aquifers in the basin generally contained small concentrations of dissolved solids and were of good drinking-water quality (Cowdery, 1998). Maximum, minimum, and median concentrations of specific conductance, dissolved solids, calcium, magnesium, sodium, sulfate, and iron were largest in samples collected from the Buffalo aquifer (Wolf, 1981) and from the Red River Valley Lake Plain physiographic area (table 13 and fig. 12). However, the quality of ground water in the aquifers varied with physiographic area (Cowdery, 1998). Samples collected from the Otter Tail surficial aquifer (Moraine physiographic area) and from the aquifers in the eastern part of the basin (Wadena, Pineland Sands, and Bemidji-Bagley surficial aquifers) contained larger median concentrations of nitrate (as nitrogen) than samples from the Buffalo aquifer (Red River Valley Lake Plain physiographic area) and the Pelican River sand-plain aquifer (all concentrations less than the laboratory reporting limit of $0.06 \mathrm{mg} / \mathrm{L}$ ). Median nitrate (as nitrogen) concentrations were largest in samples from the Otter Tail surficial aquifer (1964-68) (19 mg/L), and a sample from the Wadena surficial aquifer (1964-67) contained the largest nitrate (as nitrogen) concentration (138 mg/L) within the study area (table 13 and fig. 12).

Median concentrations of dissolved solids and sulfate from the two physiographic areas (Red River Valley Lake Plain and Moraine) are similar to median concentrations reported for the aquifers within those areas (fig. 12). However, nitrate (as nitrogen) concentrations in samples collected from the Red River Valley Lake Plain and Moraine physiographic areas were less than those from all of the surficial aquifers excluding the Buffalo aquifer and Pelican River sand-plain aquifer (fig. 12). Median concentrations of iron from the Red River Valley Lake Plain and Moraine areas were also different than concentrations from the aquifers within those areas (fig. 12). The median iron concentration from the Red River Valley Lake Plain physiographic area was less than concentrations from the Buffalo aquifer, and the median iron concentration from the Moraine physiographic area was substantially larger than median concentrations from the Pelican River sand-plain aquifer and the Otter Tail surficial aquifer (fig. 12).

Ground water from the Buffalo aquifer is very hard and calcium bicarbonate type. The water has a low sodium hazard and medium-to-high salinity hazard. However, flushing of the aquifer prevents the accumulation of salts and associated salinity hazards (Wolf, 1981). The long-term quality of ground water in the Buffalo aquifer was evaluated by Wolf (1981) by using analytical results from 46 samples collected in 1957 and 20 samples collected in 1978. Although the water samples were not collected from the same wells, both sets of samples were collected from across the same general extent of the aquifer (Wolf, 1981). In general, the two sets of data indicate changes in the quality of the water with time. Wolf (1981) reported that the samples collected in 1978 contained larger mean, median, and maximum concentrations of specific conductance, temperature, color, hardness, dissolved solids, calcium, magnesium, sulfate, and iron than samples collected in 1957. Water samples from 1978 also generally contained less sodium, potassium, and silica, and smaller $\mathrm{pH}$ values, sodium percentages, and sodium-adsorption ratios than in 1957 (Wolf, 1981). Selected water-quality data from the Buffalo aquifer are summarized in table 13 and figure 12.

Due to the discontinuous and variable nature of the Beach Ridge aquifers, the quality of ground water from the deposits varies greatly within the basin and within the individual sand deposits (Stoner and others, 1993). Water-quality data for the Beach Ridge aquifers were not available.

Ground water from the Middle River surficial aquifer is hard with large concentrations of dissolved iron. The 
Table 13. Concentrations of selected water-quality constituents in surficial aquifers in Red River of the North Basin, Minnesota.

[ $\mu \mathrm{S} / \mathrm{cm}$, microsiemens per centimeter at 25 degrees Celsius; $\mathrm{mg} / \mathrm{L}$, milligrams per liter; max, maximum; med, median value; $>$, greater than; <, less than; --, data not available]

\begin{tabular}{|c|c|c|c|c|c|c|c|c|c|c|c|c|c|c|c|c|c|c|c|}
\hline \multirow[t]{2}{*}{ Aquifer name } & \multirow[t]{2}{*}{$\begin{array}{l}\text { Date of } \\
\text { sample } \\
\text { collection }\end{array}$} & \multicolumn{2}{|c|}{$\begin{array}{c}\text { Specific } \\
\text { conductance } \\
(\mu \mathrm{S} / \mathrm{cm})\end{array}$} & \multicolumn{2}{|c|}{$\begin{array}{l}\text { Dissolved } \\
\text { solids } \\
\text { (mg/L) }\end{array}$} & \multicolumn{2}{|c|}{$\begin{array}{l}\text { Calcium } \\
\text { (mg/L) }\end{array}$} & \multicolumn{2}{|c|}{$\begin{array}{l}\text { Magnesium } \\
\quad(\mathrm{mg} / \mathrm{L})\end{array}$} & \multicolumn{2}{|c|}{$\begin{array}{l}\text { Sodium } \\
\text { (mg/L) }\end{array}$} & \multicolumn{2}{|c|}{$\begin{array}{l}\text { Sulfate } \\
\text { (mg/L) }\end{array}$} & \multicolumn{2}{|c|}{$\begin{array}{l}\text { Chloride } \\
\text { (mg/L) }\end{array}$} & \multicolumn{2}{|c|}{$\begin{array}{c}\text { Nitrate } \\
\text { (as nitrogen) } \\
\text { (mg/L) }\end{array}$} & \multicolumn{2}{|c|}{$\begin{array}{l}\text { Iron } \\
\text { (mg/L) }\end{array}$} \\
\hline & & $\max$ & med & $\max$ & med & $\max$ & med & $\max$ & med & $\max$ & med & $\max$ & med & $\max$ & med & $\max$ & med & $\max$ & med \\
\hline \multirow[t]{2}{*}{ Buffalo aquifer } & 1957 & 1,500 & 789 & 1,190 & 490 & 181 & 84 & 83 & 33 & 159 & 21 & 545 & 108 & 39 & 3.5 & -- & -- & 4.6 & 0.73 \\
\hline & 1978 & 2,250 & 828 & 1,990 & 604 & 260 & 110 & 230 & 40 & 140 & 10 & 1,100 & 190 & 54 & 4.4 & 10 & 0 & 45 & 7.4 \\
\hline $\begin{array}{l}\text { Beach Ridge } \\
\text { aquifers }\end{array}$ & -- & -- & -- & -- & -- & -- & -- & -- & -- & -- & -- & -- & -- & -- & -- & -- & -- & -- & -- \\
\hline $\begin{array}{l}\text { Middle River } \\
\text { surficial aquifer }\end{array}$ & 1965 & -- & -- & -- & -- & -- & -- & -- & -- & -- & -- & -- & -- & $>600$ & -- & -- & -- & -- & -- \\
\hline $\begin{array}{l}\text { Two Rivers } \\
\text { surficial aquifer }\end{array}$ & 1969 & -- & -- & $<500$ & -- & -- & -- & -- & -- & -- & -- & -- & -- & -- & -- & -- & -- & -- & -- \\
\hline $\begin{array}{l}\text { Pelican River } \\
\text { sand-plain } \\
\text { aquifer }\end{array}$ & 1965-73 & 1,270 & 542 & 708 & 298 & 93 & 75 & 28 & 23 & 140 & 2.7 & 32 & 17 & 170 & 5.7 & .02 & .02 & 1.7 & .05 \\
\hline \multirow{2}{*}{$\begin{array}{l}\text { Otter Tail surficial } \\
\text { aquifer }\end{array}$} & 1965-68 & 1,020 & 436 & 655 & 272 & 150 & 50 & 42 & 25 & 19 & 3.3 & 37 & 20.5 & 42 & 3.9 & 24 & 3.8 & .22 & .22 \\
\hline & 1964-68 & 570 & 354 & 680 & 238 & 108 & 47 & 31 & 22 & 9.6 & 2.8 & 51 & 16 & 14 & 2.7 & 80 & 19 & 5.9 & .07 \\
\hline \multirow{2}{*}{$\begin{array}{l}\text { Wadena surficial } \\
\text { aquifer }\end{array}$} & 1970 & 950 & 585 & 730 & 371 & 116 & 81.5 & 37 & 22 & 32 & 5.3 & 96 & 15 & 52 & 6 & 138 & 7.2 & 4.5 & .5 \\
\hline & 1979 & 867 & 460 & 520 & 280 & 110 & 61 & 31 & 16 & 50 & 3.4 & 39 & 10 & 41 & 4.3 & 23 & .34 & 5.5 & .13 \\
\hline \multirow{2}{*}{$\begin{array}{l}\text { Pineland Sands } \\
\text { surficial aquifer }\end{array}$} & $1975-76$ & 661 & 420 & 359 & 245 & 110 & 62 & 21 & 15 & 12 & 2.9 & 35 & 5.9 & 22 & 2.5 & 20 & .95 & 13 & .75 \\
\hline & 1988-89 & 790 & 390 & 330 & 252 & 120 & 66 & 34 & 20 & 18 & 3.7 & 34 & 6.4 & 57 & 4.8 & 35 & 3.5 & -- & -- \\
\hline $\begin{array}{l}\text { Bemidji-Bagley } \\
\text { surficial aquifer }\end{array}$ & 1987-88 & 1,800 & 460 & 1,020 & 281 & 190 & 70 & 64 & 17 & 230 & 3.4 & 25 & 9.3 & 380 & 4.5 & 7.8 & 1.4 & 20 & .02 \\
\hline $\begin{array}{l}\text { Maximum } \\
\text { concentration }\end{array}$ & & 2,250 & 828 & 1,990 & 604 & 260 & 110 & 230 & 40 & 230 & 21 & 1,100 & 190 & 380 & 6.0 & 138 & 19 & 45 & 7.4 \\
\hline $\begin{array}{l}\text { Minimum } \\
\text { concentration }\end{array}$ & & 570 & 354 & 330 & 238 & 93 & 47 & 21 & 15 & 9.6 & 2.7 & 25 & 5.9 & 14 & 2.5 & .02 & 0 & .22 & .02 \\
\hline $\begin{array}{l}\text { Mean } \\
\text { concentration }\end{array}$ & & 1,168 & 526 & 818 & 333 & 144 & 71 & 60 & 23 & 81 & 5.9 & 199 & 40 & 87 & 4.2 & 38 & 4.0 & 11 & 1.1 \\
\hline $\begin{array}{l}\text { Median } \\
\text { concentration }\end{array}$ & & 985 & 460 & 694 & 281 & 118 & 68 & 36 & 22 & 41 & 3.4 & 38 & 16 & 47 & 4.4 & 23 & 1.4 & 5.5 & .22 \\
\hline
\end{tabular}



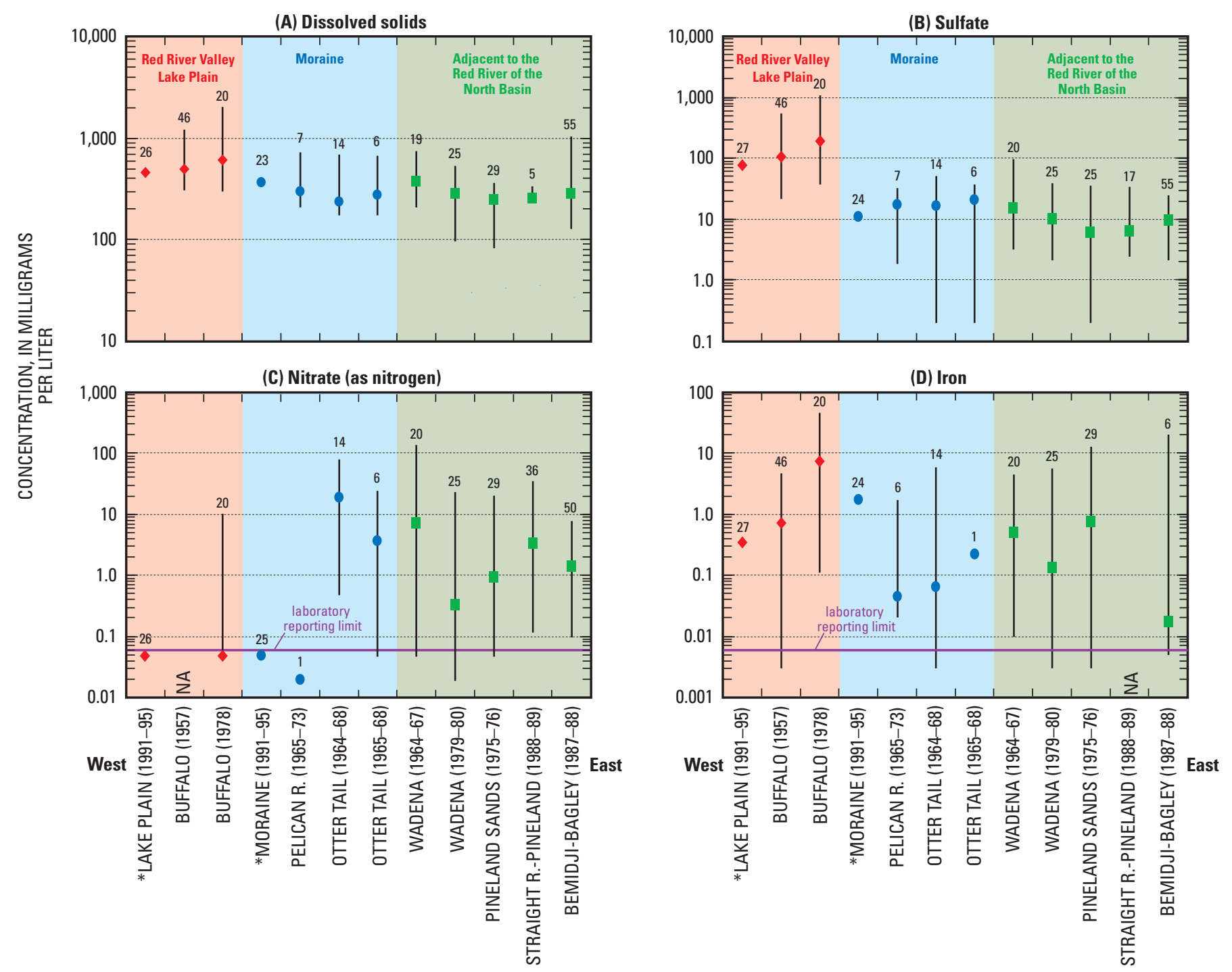

AQUIFERS AND PHYSIOGRAPHIC AREAS (figs. 1 and 2)

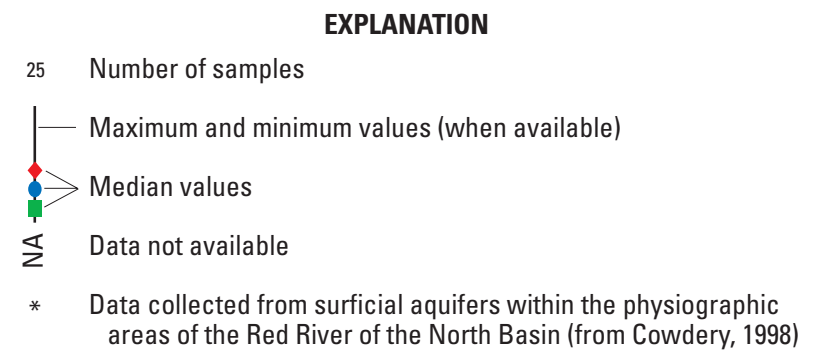

Figure 12. Concentrations of $(A)$ dissolved solids, $(B)$ sulfate, $(C)$ nitrate (as nitrogen), and $(D)$ iron in water from selected surficial aquifers and physiographic areas. 
concentrations of chloride ranged from $50 \mathrm{mg} / \mathrm{L}$ in the eastern part of the aquifer to more than $600 \mathrm{mg} / \mathrm{L}$ in the northwestern part (table 13) (Maclay and others, 1965). Water-quality data available for the Middle River surficial aquifer are summarized in table 13.

The Two Rivers surficial aquifer contains bicarbonate type water that is very hard. In general, the water has large carbonate concentrations and as much as 5 to $9 \mathrm{mg} / \mathrm{L}$ of iron (Maclay and others, 1967). Water pumped from deeper wells within the aquifer may contain concentrations of hydrogen sulfide gas (Maclay and others, 1967). The relatively small concentrations of dissolved solids in water from the aquifer, generally less than $500 \mathrm{mg} / \mathrm{L}$ (table 13), indicate a relatively short time period that the ground water was in contact with aquifer material (Maclay and others, 1967). Available water-quality data for the Two Rivers surficial aquifer are summarized in table 13.

Ground water in the Pelican River sand-plain aquifer is calcium magnesium bicarbonate type and is very hard (Anderson, 1980; Miller, 1982). Ground water from the aquifer has a low sodium hazard and does not pose risks for irrigation purposes. However, increased pumping for irrigation could cause the build-up of salts (Miller, 1982). Concentrations of iron and manganese in ground water generally exceeded standards of 0.3 and $0.05 \mathrm{mg} / \mathrm{L}$, respectively, recommended by the U.S. Environmental Protection Agency (1986). Selected waterquality data from the Pelican River sand-plain aquifer are summarized in table 13 and figure 12.

The Otter Tail surficial aquifer contains water that is calcium bicarbonate type and generally has a hardness greater than $200 \mathrm{mg} / \mathrm{L}$. Water from the aquifer has a low sodium hazard and a medium salinity hazard (Winter and others, 1969). Water hardness and dissolved concentrations of chloride, nitrate, iron, and (or) manganese vary depending on location and land-use practices across the aquifer (Winter and others, 1969; Reeder, 1972). Nitrate concentrations exceeded U.S. Environmental Protection Agency (1986) recommended drinking-water standard of $10 \mathrm{mg} / \mathrm{L}$ in two of the six samples collected by Anderson (1980). Selected water-quality data from the Otter Tail surficial aquifer are presented in table 13 and figure 12.

Water in the Wadena surficial aquifer is calcium bicarbonate type and very hard. Hardness is attributed to the dissolution of a large percentage of the carbonate rock fragments present within the outwash sand and gravel and the underlying till. The water has a low sodium hazard and a medium to high salinity hazard (Lindholm, 1970). Locally large concentrations of nitrate were measured in shallow ground-water samples and attributed to human and agricultural activities, including septic tank effluent, fertilization, and livestock (Lindholm, 1970). Selected water-quality data from the Wadena surficial aquifer are summarized in table 13 and figure 12.

The Pineland Sands surficial aquifer contains calcium bicarbonate water that is moderately hard to very hard. Mineralization and hardness typically are greater in the northwestern one-half of the aquifer as a result of geographic variation in mineral solubility and longer contact time between soluble minerals and ground water (Helgesen, 1977). Analyses of ground water from the aquifer indicated a low sodium hazard and low to medium salinity hazard (Helgesen, 1977). Nitrate concentrations in shallow parts of the aquifer near the Straight River exceeded U.S. Environmental Protection Agency (1986) drinking-water standard of $10 \mathrm{mg} / \mathrm{L}$ and generally were larger in samples collected near the water table. However, nitrate concentrations in water collected from deeper wells were less than $1.0 \mathrm{mg} / \mathrm{L}$ (Stark and others, 1994). Selected water-quality data from the Pineland Sands surficial aquifer are summarized in table 13 and figure 12.

Ground water from the Bemidji-Bagley surficial aquifer is very hard and a calcium bicarbonate type. The water has a low sodium hazard and a medium to high salinity hazard (Stark and others, 1991). The concentrations of dissolved solids locally exceeded Minnesota Pollution Control Agency (1988) recommended standards for agricultural and wildlife use and frequently exceeded recommended levels for domestic use (Stark and others, 1991). Elevated concentrations of cations and anions were likely related to local land use (Stark and others, 1991). The effects of these practices were more pronounced in the quality of the water in the surficial aquifer than in the confined aquifer (Stark and others, 1991). Mean concentrations of specific conductance, temperature, dissolved solids, calcium, sodium, potassium, sulfate, chloride, silica, ammonia plus organic nitrogen, and phosphorus were larger and more variable in water from wells within the surficial aquifer located in commercial and residential land-use areas than in wells located in agricultural and forested areas. Mean concentrations of magnesium, fluoride, and ammonia nitrogen generally were larger in water from wells within commercial land-use areas than in wells within forested and agricultural areas, and the mean nitrate (as nitrogen) concentration was larger in water from residential land-use area wells than from wells in forested and agricultural areas (Stark and others, 1991). It also is likely that the variable concentrations detected in the surficial aquifer indicated mixing with water from the confined aquifer (Stark and others, 1991). Selected water-quality data from the BemidjiBagley surficial aquifer are presented in table 13 and figure 12.

\section{Implications of Study}

Evaluating the availability of ground water in the surficial aquifers of the study area is an initial step for water managers in determining the long-term, sustainable use of ground water in the Red River of the North Basin. Hydrogeologic and hydraulic characteristics and properties, sources and losses of water in an aquifer, and ground-water storage are essential to understanding and describing an aquifer system. Well yields, groundwater pumping and use, water quality, and the interactions of ground water with surface water (during periods of pumping and recovery) also provide valuable information in assessing the availability of ground water.

The availability of ground water from an aquifer is based on the effects of ground-water pumping on the aquifer and the 
surrounding environment and the relevance of these effects, either positive or negative, with respect to ground-water needs and uses. This report provides an evaluation of the availability of ground water in the study area; however, the conclusions regarding availability of water do not imply the sustainable uses (or quantities) of ground water from the aquifers. Although hydrologic properties and scientific methods provide a foundation of information about an aquifer, the availability of ground water from an aquifer, and therefore, the sustainability also need to be evaluated by water managers with respect to economic and social policies and planning.

Water budgets, either derived from measured or hypothetical values, provide estimates of the sources and losses of water and the total volume of ground water available in each aquifer. The inflow of water to an aquifer (total recharge) is an important component of the water budget, as the difference between inflows and losses (discharge) of water affects ground-water levels and storage. Greater rates of inflow imply greater potential availability of ground water. Therefore, understanding and estimating the sources of inflow provide vital information for assessing ground-water availability. Water-budget estimates summarized in this report suggest that total recharge rates are greatest in the Otter Tail, Wadena, Pineland Sands, and Bemidji-Bagley surficial aquifers and least in the Middle River surficial aquifer.

Estimates of ground-water storage in the aquifers, calculated or summarized from published reports, represent the maximum volume of ground water that is capable of being stored in an aquifer and are not the actual, available volumes of ground water. Because the aquifers are considered to have long-term, steady-state conditions, sources of water are approximately equal to losses, and water in storage minimizes fluctuations in the water budget. The Pelican River sand-plain aquifer and Otter Tail, Pineland Sands, and Two Rivers surficial aquifers are capable of storing the largest volumes of ground water in the study area. The Middle River surficial aquifer has the least potential volume for storing ground water.

Theoretical well yields in the study area are greatest in the Buffalo aquifer, Pelican River sand-plain aquifer, and Otter Tail and Pineland Sands surficial aquifers. The majority of groundwater pumped from the aquifers in 2003 was from the Otter Tail, Pineland Sands, and Wadena surficial aquifers. In addition to having the smallest theoretical well yields, the volume of ground water withdrawn from the Middle River surficial aquifer was the smallest in the study area.

On the basis of available water-quality data, in general the Buffalo aquifer contained the largest concentrations of constituents, including specific conductance, dissolved solids, calcium, magnesium, sulfate, and iron (table 13 and figure 12). Concentrations of selected constituents were smallest in the Pelican River sand-plain aquifer and Otter Tail and Pineland Sands surficial aquifers relative to the other aquifers in the study area. On the basis of characteristics and hydraulic properties, estimated water budgets, theoretical well yields, ground-water storage and use, and water quality, the Otter Tail and Pineland Sands surficial aquifers and the Pelican River sand-plain aquifer have the greatest potential for additional development of ground-water resources within the study area.

\section{Summary and Conclusions}

The assessment of ground-water availability from the nine surficial aquifers within the Minnesota part of the Red River of the North Basin (Buffalo, Beach Ridge, Middle River, Two Rivers, Pelican River, Otter Tail, Wadena, Pineland Sands, and Bemidji-Bagley) requires an understanding and evaluation of numerous aquifer characteristics, including (1) location and extent; (2) physical characteristics and hydraulic properties; (3) the volume of water within the aquifer determined on the basis of sources and losses to and from the aquifer and the maximum amount of water capable of being stored in the aquifer; (4) the ability (or inability) to withdraw ground water from the aquifer (that is, theoretical well yields and ground-water pumping data); (5) the intended uses of the ground water and the necessary quality of the water for the intended uses; and (6) the hydraulic connection between the aquifer and surrounding surface water. Information regarding the availability of ground water from the aquifers in the study area was compiled and summarized from previously published studies.

Water-budget estimates for selected aquifers in the study area were compiled from published information, including steady-state aquifer simulations; precipitation data, hydrograph analysis, and infiltration capacities of soils; and recharge and discharge components determined for the aquifer. The water budgets provided a method of comparing the sources and losses of water and the volume of ground water available within each of the aquifers. The major sources of recharge to the surficial aquifers include areal recharge, primarily from the infiltration of precipitation; flow from surface water; and flow across aquifer boundaries from adjacent geologic units. Losses of water from the aquifers are the result of evapotranspiration, flow to surface water, flow across aquifer boundaries to adjacent geologic units, and ground-water withdrawals by pumping wells.

On the basis of water-budget estimates for the aquifers summarized in this report, the Bemidji-Bagley, Otter Tail, Pineland Sands, and Wadena surficial aquifers have the highest rates of total water inflow (and outflow), ranging from 44,000 to $92,000 \mathrm{Mgal} / \mathrm{yr}$, of the nine aquifers located within the study area. Conversely, water-budget information indicates that the Middle River surficial aquifer has the lowest rate (approximately 1,100 Mgal/yr) of total water inflow and outflow.

The maximum volume of ground water that is capable of being stored in the surficial aquifers was estimated using areal extent and published saturated thickness and porosity data (Pelican River sand-plain aquifer and Bemidji-Bagley, Otter Tail, Pinelands Sands, and Wadena surficial aquifers) or prorated using published estimates of ground-water storage volumes (Two Rivers surficial aquifer). Ground-water storage estimates were summarized for the Buffalo aquifer and Middle River 
surficial aquifer from published studies. The volume of ground water capable of being stored in each of the aquifers ranged from 4.6 bgal in the Middle River surficial aquifer to 1,000 bgal in the Pineland Sands surficial aquifer. The Otter Tail and Two Rivers surficial aquifers and Pelican River sand-plain aquifer are capable of storing relatively large volumes of ground water, ranging from 300 to $500 \mathrm{bgal}$. The total volume of ground water that is capable of being stored within the eight surficial aquifers, excluding the Beach Ridge aquifers, was estimated to be approximately 2,875 bgal. Due to the variable and limited extent and the absence of hydrologic and hydraulic data,

ground-water storage estimates were not determined or available for the Beach Ridge aquifers.

Maximum theoretical well yields for the aquifers generally occur in areas with abundant, well-sorted, coarse-grained sediment. Specific areas of the Buffalo aquifer have the greatest potential to yield ground water to pumping wells. Maximum well yields in the nine aquifers range from $10,000 \mathrm{gal} / \mathrm{min}$ in the Buffalo aquifer to $50 \mathrm{gal} / \mathrm{min}$ in the Middle River surficial aquifer. Relatively large well yields also were determined for the Otter Tail and Pineland Sands surficial aquifers and the Pelican River sand-plain aquifer. Areas of the surficial aquifers that produced the largest theoretical well yields are limited in size and likely would not support long-term high rates of ground-water pumping.

In 2003, 28 bgal of ground water were withdrawn from the nine aquifers, not including water used for private supply. The largest volume of ground water was pumped from the Otter Tail surficial aquifer (9,173 Mgal), and the smallest volume (26 Mgal) was pumped from the Middle River surficial aquifer. Ground water from the Otter Tail, Pineland Sands, and Wadena surficial aquifers represented 87 percent of the ground-water resources withdrawn in the study area in 2003. Agricultural irrigation and public supply were the largest uses of ground water withdrawn from the aquifers in 2003 , totaling about 95 percent of the total volume withdrawn.

Information on ground-water quality through analysis of selected constituents in the surficial aquifers was compiled and summarized from previously conducted studies. Water-quality data were not available for the Beach Ridge aquifers and Middle River and Two Rivers surficial aquifers. Water samples from the remaining aquifers generally contained small concentrations of dissolved solids and were of good drinking-water quality. In general, concentrations of specific conductance, dissolved solids, calcium, magnesium, sodium, sulfate, and iron were largest in the Buffalo aquifer. Ground water from the Bemidji-Bagley, Otter Tail, Pineland Sands, and Wadena surficial aquifers contained larger concentrations of nitrate (as nitrogen) than the other aquifers.

Although information regarding ground-water development and the effects on local surface-water bodies is limited and specific to each hydrologic system, in general the data indicate that each of the nine surficial aquifer systems are hydraulically connected to local surface water. Ground-water development simulations conducted for some of the aquifers describe correlations between increased ground-water withdrawals and declining lake elevations and streamflows, declining groundwater levels, and (or) variations in the quality of ground-water resources.

The relation between net ground-water sources and losses, aquifer storage, use and safe yield, and water quality are important in evaluating the availability of ground water. On the basis of characteristics and hydraulic properties, estimated water budgets, theoretical well yields, ground-water storage and use, and water quality, the Otter Tail and Pineland Sands surficial aquifers and the Pelican River sand-plain aquifer have the greatest potential for additional development of ground-water resources within the study area. However, estimates of groundwater recharge, discharge, and storage cannot exclusively be used to determine the amount of ground water that can be withdrawn on a sustained basis. The sustainability (and therefore, availability) of ground water also is dependent on changes in the flow of water and the effects on the aquifer and the surrounding environment as a result of pumping and the acceptable tradeoffs between ground-water use and these changes. This report is intended to describe and evaluate some of the hydrologic characteristics necessary as a first step for water managers in determining the sustainable use of ground water from the surficial aquifers in the study area.

\section{Selected References}

Alexander, S.C., and Alexander, E.C., Jr., 1989, Residence times of Minnesota ground waters: Minnesota Academy of Sciences Journal, v. 55, no. 1, p. 48-52.

Alley, W.M., and Leake, S.A., 2004, The journey from safe yield to sustainability: Ground Water, v. 42, no. 1, p. 12-16.

Alley, W.M., Reilly, T.E., and Franke, O.L., 1999, Sustainability of ground-water resources: U.S. Geological Survey Circular 1186, accessed June 7, 2005, at http://pubs.water.usgs.gov/circ1186

Anderson, H.W., 1980, Hydrogeological reconnaissance of selected sand-plain aquifers in central Minnesota: Unpublished report on file with the U.S. Geological Survey, Mounds View, Minnesota.

Anderson, H.W., Jr., and Stoner, J.D., 1989, Effects of controlled agricultural practices on water quality in a Minnesota sand-plain aquifer: U.S. Geological Survey Open-File Report 89-267, 2 p.

Armstrong, C.A., 1982, Ground water resources of Ransom and Sargent Counties, North Dakota, part III: North Dakota Geological Survey Bulletin 69 and North Dakota Water Commission County Ground-Water Studies 31, 51 p.

Baker, C.H., Jr., and Paulson, Q.F., 1967, Geology and ground water resources, Richland County, North Dakota, part III: North Dakota Geological Survey Bulletin 46 and North Dakota Water Commission County Ground-Water Studies 7, $45 \mathrm{p}$.

Baker, D.G., and Kuehnast, E.A., 1978, Climate of Minnesota, part X. Precipitation normals for 1941-1970: Minnesota 
Agricultural Experimentation Station Technical Bulletin 314, $15 \mathrm{p}$.

Baker, D.G., Nelson, W.W., and Kuehnast, E.A., 1979, Climate of Minnesota, part XII. The hydrologic cycle and soil and water: Minnesota Agricultural Experimentation Station Technical Bulletin 322, 23 p.

Bidwell, L.E., Winter, T.C., and Maclay, R.W., 1970, Water resources of the Red Lake River watershed, northwestern Minnesota: U.S. Geological Survey Hydrologic Investigations Atlas HA-346, 4 sheets, scale 1:250,000.

Bredehoeft, J.D., 1997, Safe yield and the water budget myth: Ground Water, v. 35, no. 6, p. 929.

Brunett, J.O., Barber, N.L., Burns, A.W., Fogelman, R.P., Gilles, D.C., Lindwin, R.A., and Mack, T.J., 1997, A qualityassurance plan for district ground-water activities of the U.S. Geological Survey: U.S. Geological Survey Open-File Report 97-11, $21 \mathrm{p}$.

Byers, A.C., Wenzel, L.K., Laird, W.M., and Dennis, P.E., 1946, Ground water in the Fargo-Moorhead area, North Dakota and Minnesota: U.S. Geological Survey, 72 p.

Cotter, R.D., and Bidwell, L.E., 1966, Water resources of the Pomme De Terre River watershed, west-central Minnesota: U.S. Geological Survey Hydrologic Investigations Atlas HA-220, 4 sheets, scale 1:250,000.

Cotter, R.D., Bidwell, L.E., Oakes, E.L., and Hollenstein, G.H., 1966, Water resources of the Big Stone Lake watershed, west-central Minnesota: U.S. Geological Survey Hydrologic Investigations Atlas HA-213, 4 sheets, scale 1:250,000.

Cowdery, T.K., 1995, Similar agricultural areas, different ground-water quality-Red River of the North Basin, 1993-95: U.S. Geological Survey Open-File Report 95-441, $4 \mathrm{p}$.

Cowdery, T.K., 1997, Shallow ground-water quality beneath cropland in the Red River of the North Basin, Minnesota and North Dakota, 1993-95: U.S. Geological Survey WaterResources Investigations Report 97-4001, 52 p.

Cowdery, T.K., 1998, Ground-water quality in the Red River of the North Basin, Minnesota and North Dakota, 1991-95: U.S. Geological Survey Water-Resources Investigations Report 98-4175, 15 p.

Cowdery, T.K., 2004, Ground-water evapotranspiration estimates near wet meadows using well hydrographs [abs.]: Minnesota Water 2004-Policy and planning to ensure Minnesota's water supplies, March 23-24, 2004, p. 44.

Cowdery, T.K., and Saylor, K.N., 1996, Contrasting water quality of two surficial aquifers in the Red River of the North drainage basin, North Dakota and Minnesota [abs.]: Minnesota Water '96, Changing patterns of power and responsibility-Implications for water policy, Minneapolis, Minnesota, May 20-21, 1996: Water Resources Research Center, University of Minnesota, St. Paul, Minnesota, p. 98.

Cowdery, T.K., and Saylor, K.N., 1996, Contrasting water quality of two surficial aquifers in the Red River of the North drainage basin, North Dakota and Minnesota [abs.]: North Dakota Water-Quality Symposium, Bismarck, North Dakota, March 20-21, 1996, p. 146.
Cowdery, T.K., and Stoner, J.D., 1996, Changes in nitrate concentrating in a surficial aquifer between upland recharge and stream discharge, northwestern Minnesota [abs.]: Journal of the Minnesota Academy of Science, v. 61, no. 1, p. 4.

Delin, G.N., 1986, Hydrogeology of confined-drift aquifers near the Pomme de Terre and Chippewa Rivers, western Minnesota: U.S. Geological Survey Water-Resources Investigations Report 86-4098, 90 p.

Delin, G.N., 1995, Aquifer test in a complex drift aquifer system, west-central Minnesota: Hydrological Science and Technology, v. 11, no. 1-4, p. 1-13.

Froelich, L.J., 1974, Geohydrology of the Wahpeton area, Richland County, North Dakota: North Dakota State Water Commission, North Dakota Ground-Water Studies, no. 76, 91 p.

Gunard, K.T., Hess, J.H., Zirbel, J.L., and Cournelius, C.E., 1990, Water-resources data for Minnesota water year 1988, volume 2, Upper Mississippi and Missouri River Basins: U.S. Geological Survey Water-Data Report MN-88-2, p. $65-70$.

Hantush, M.S., 1960, Modification of the theory of leaky aquifers: Journal of Geophysical Research, v. 94, p. 1921-1932.

Helgesen, J.O., 1977, Ground-water appraisal of the Pineland Sands area, central Minnesota: U.S. Geological Survey Water-Resources Investigations Report 77-102, 49 p.

Hobbs, H.C., and Goebel, J.E., 1982, Geologic map of Minnesota-Quaternary geology: Minnesota Geological Survey State Map Series 1, scale 1:500,000.

Krumbein, W.C., and Monk, G.D., 1943, Transactions of the Petroleum Division: American Institute of Mining and Metallurgical Engineering, v. 151, p. 153-163.

Kruseman, G.P., and de Ridder, N.A., 1990, Analysis and evaluation of pumping test data (2nd ed.): International Institute for Land Reclamation and Improvement Publication 47, $377 \mathrm{p}$.

Larson, S.P., McBride, M.S., and Wolf, R.J., 1975, Digital models of a glacial outwash aquifer in the Pearl-Sallie Lakes area, west-central Minnesota: U.S. Geological Survey Water-Resources Investigations Report 75-40, 39 p.

Lindgren, R.J., 1996, Availability and quality of water from drift aquifers in Marshall, Pennington, Polk, and Red Lake Counties, northwestern Minnesota: U.S. Geological Survey Water-Resources Investigations Report 95-4201, 144 p.

Lindgren, R.J., 2002, Ground-water resources of the uppermost confined aquifers, southern Wadena County and parts of Otter Tail, Todd, and Cass Counties, central Minnesota, 1997-2000: U.S. Geological Survey Water-Resources Investigations Report 02-4023, 57 p.

Lindholm, G.F., 1970, An appraisal of ground water for irrigation in the Wadena area, central Minnesota: U.S. Geological Survey Water-Supply Paper 1983, 56 p.

Lindholm, G.F., 1980, Ground-water appraisal of sand plains in Benton, Sherburne, Stearns, and Wright Counties, central Minnesota: U.S. Geological Survey Water-Resources Investigations Report 80-1285, 103 p. 
Lindholm, G.F., and Norvitch, R.F., 1976, Ground water in Minnesota: U.S. Geological Survey Open-File Report 76-354, 100 p.

Lindholm, G.F., Oakes, E.L., Ericson, D.W., and Helgesen, J.O., 1972, Water resources of the Crow Wing River watershed, central Minnesota: U.S. Geological Survey Hydrologic Investigations Atlas HA-380, 4 sheets, scale 1:250,000.

Lorenz, D.L., 1992, Using a geographic information system to describe the environmental setting of the Red River of the North Basin [abs.], in Balthrop, B.H., and Baker, E.G., eds., U.S. Geological Survey National Computer Technology Meeting-Program and abstracts, May 17-22, 1992, Norfolk, Virginia: U.S. Geological Survey Open-File Report 92-64, p. 21.

Lorenz, D.L., and Stoner, J.D., 1996, Sampling design for assessing water quality in the Red River of the North Basin, North Dakota, South Dakota, and Minnesota, 1993-95: U.S. Geological Survey Water-Resources Investigations Report 96-4129, 2 plates.

Maclay, R.W., 1963, Evaluation of ground-water resources near Stephen, Minnesota: U.S. Geological Survey, 24 p.

Maclay, R.W., Bidwell, L.E., and Winter, T.C., 1968, Water resources of the Mustinka and Bois de Sioux Rivers watershed, west-central Minnesota: U.S. Geological Survey Hydrologic Investigations Atlas HA-272, 4 sheets, scale $1: 250,000$.

Maclay, R.W., Bidwell, L.E., and Winter, T.C., 1969, Water resources of the Buffalo River watershed, west-central Minnesota: U.S. Geological Survey Hydrologic Investigations Atlas HA-307, 3 sheets, scale 1:250,000.

Maclay, R.W., and Winter, T.C., 1967, Geochemistry and ground-water movement in northwestern Minnesota: Ground Water, v. 5, no. 1, p. 11-19.

Maclay, R.W., Winter, T.C., and Bidwell, L.E., 1972, Water resources of the Red River of the North drainage basin in Minnesota: U.S. Geological Survey Water-Resources Investigations Report 1-72, 129 p.

Maclay, R.W., Winter, T.C., and Pike G.M., 1965, Water resources of the Middle River watershed, northwestern Minnesota: U.S. Geological Survey Hydrologic Investigations Atlas HA-201, 3 sheets, scale 1:250,000.

Maclay, R.W., Winter, T.C., and Pike G.M., 1967, Water resources of the Two Rivers watershed, northwestern Minnesota: U.S. Geological Survey Hydrologic Investigations Atlas HA-237, 4 sheets, scale 1:250,000.

Magner, J., Regan, C., and Trojan, M., 1997, Isotopic characterization of the Buffalo River watershed and the Buffalo aquifer near Moorhead Municipal Well One: Unpublished report on file with the Minnesota Pollution Control Agency, St. Paul, Minnesota.

Miller, R.T., 1981, Hydrologic data for the Pelican River sandplain aquifer, western Minnesota: U.S. Geological Survey Open-File Report 80-695, 86 p.

Miller, R.T., 1982, Appraisal of the Pelican River sand-plain aquifer, western Minnesota: U.S. Geological Survey OpenFile Report 82-347, 44 p.
Minnesota Department of Natural Resources, 2000, Regional hydrogeologic assessment southern Red River Valley, Minnesota: RHA-3 part B, 2 plates, scale 1:200,000.

Minnesota Department of Natural Resources, 2002, Regional hydrogeologic assessment Otter Tail area, west-central Minnesota: RHA-5 part B, 2 plates, and Technical Appendix, scale 1:200,000.

Minnesota Department of Natural Resources, 2003, Water use-Water Appropriations Permit Program, water use data 1988 to 2004: Minnesota Department of Natural Resources, Division of Waters, accessed October 15, 2004, at http://www.dnr.state.mn.us/waters/watermgmt_section/ appropriations/wateruse.html

Minnesota Department of Natural Resources, 2005, Sustainability of Minnesota's ground water-a statement of issues and needs: Minnesota Department of Natural Resources, Division of Waters, accessed June 13, 2005, at http://www.dnr.state.mn.us/waters/index.html

Minnesota Geological Survey, 1995, Regional hydrogeologic assessment, Quaternary geology - southern Red River Valley, Minnesota: RHA-3 part A, 2 plates, scale 1:200,000.

Minnesota Geological Survey, 1999, Regional hydrogeologic assessment, Quaternary geology_Otter Tail area, west-central Minnesota: RHA-5 part A, 2 plates, scale 1:200,000.

Minnesota Pollution Control Agency, 1988, Minnesota code of agency rules - standards for protection of the quality and purity of the waters of the State: Minnesota Pollution Control Agency Division of Water Quality Regulations, Minnesota Rules, chapt. 7050, 133 p.

Myette, C.F., 1982, Baseline water-quality data for sand-plain aquifers in Hubbard, Morrison, Otter Tail, and Wadena Counties, Minnesota: U.S. Geological Survey Open-File Report 82-909, 112 p.

Myette, C.F., 1984, Ground-water-quality appraisal of sandplain aquifers in Hubbard, Morrison, Otter Tail, and Wadena Counties, Minnesota: U.S. Geological Survey WaterResources Investigations Report 84-4080, 49 p.

Puckett, L.J., and Cowdery, T.K., 2002, Transport and fate of nitrate in a glacial outwash aquifer in relation to ground water age, land use practices, and redox processes: Journal of Environmental Quality, v. 31, no. 3, p. 782-796.

Puckett, L.J., Cowdery, T.K., Lorenz, D.L., and Stoner, J.D., 1999, Estimation of nitrate contamination of an agroecosystem outwash aquifer using a nitrogen mass-balance budget: Journal of Environmental Quality, v. 28, no. 6, p. 2015-2025.

Reeder, H.O., 1969, Ground water for irrigation in the Perham area, Otter Tail County, west-central Minnesota: U.S. Geological Survey Open-File Report, 56 p.

Reeder, H.O., 1972, Availability of ground water for irrigation from glacial outwash in the Perham area, Otter Tail County, Minnesota: U.S. Geological Survey Water-Supply Paper 2003, 45 p.

Ripley, D.P., 1992, The cleanup and protection of the Wahpeton buried valley aquifer system, Richland County, North Dakota-groundwater data: North Dakota State WaterCommission Water Resource Investigation 20, part 1, 296 p. 
Ruhl, J.F., 1994, Nitrate-N concentration distribution and the presence of selected pesticides in the surficial sand aquifer of the Straight River Basin, north-central Minnesota, 1991-93 [abs.]: Midwest Ground-Water Conference, 39th, Bismarck, North Dakota, October 16-18, 1994, p. 28.

Ruhl, J.F., 1995, Presence, distribution, and potential sources of nitrate and selected pesticides in the surficial aquifer along the Straight River in north-central Minnesota, 1992-1993: U.S. Geological Survey Water-Resources Investigations Report 95-4151, 24 p.

Ruhl, J.F., 1996, Relation of land use to nitrate in the surficial aquifer along the Straight River, north-central Minnesota, 1992-1993: U.S. Geological Survey Fact Sheet 099-96, 2 p.

Ruhl, J.F., 1997, Nitrate and pesticides in surficial aquifers and trophic state and phosphorus sources for selected lakes, eastern Otter Tail County, west-central Minnesota, 1993-96: U.S. Geological Survey Water-Resources Investigations Report 97-4085, 43 p.

Schiner, G.R., 1960, Ground-water exploration and test pumping in the Halma-Lake Bronson area, Kittson County, Minnesota: U.S. Geological Survey Open-File Report, 53 p.

Schiner, G.R., 1963, Ground-water exploration and test pumping in the Halma-Lake Bronson area, Kittson County, Minnesota: U.S. Geological Survey Water-Supply Paper 1619-BB, $38 \mathrm{p}$.

Schmid, R.W., 1970, Wahpeton aquifer test: North Dakota State Water Commission Open-File Report, unnumbered and unpaged report.

Schoenberg, M.E., 1998, Hydrogeology and sources of recharge to the Buffalo and Wahpeton aquifers in the southern part of the Red River of the North drainage basin, westcentral Minnesota and southeastern North Dakota: U.S. Geological Survey Water-Resources Investigations Report 97-4084, 35 p.

Stark, J.R., 1992, Stream-aquifer relations along the Straight River, Becker and Hubbard Counties, Minnesota [abs.]: Annual Midwest Ground Water Conference, 37th, Sioux Falls, South Dakota, October 14-16, 1992, p. 36.

Stark, J.R., Armstrong, D.S., and Zwilling, D.R., 1994, Streamaquifer interactions in the Straight River area, Becker and Hubbard Counties, Minnesota: U.S. Geological Survey Water-Resources Investigations Report 94-4009, 83 p.

Stark, J.R., Busch, J.P., and Deters, M.H., 1991, Hydrogeology and water quality of glacial-drift aquifers in the BemidjiBagley area, Beltrami, Clearwater, Cass, and Hubbard Counties, Minnesota: U.S. Geological Survey Water-Resources Investigations Report 89-4136, 135 p.

Stark, J.R., and Zwilling, D.R., 1989, Effects of ground-water withdrawal for irrigation and quality of Straight River, northcentral Minnesota [abs.]: Annual Midwest Ground Water Conference, 34th, Kalamazoo, Michigan, October 18-20, 1987, p. 11.

Stark, J.R., and Zwilling, D.R., 1989, Effects of ground-water withdrawals for irrigation on the quality of the Straight River, north-central Minnesota: U.S. Geological Survey Open-File Report 89-252, 2 p.
Stark, J.R., and Zwilling, D.R., 1990, Effects of ground-water withdrawal for irrigation and quality of Straight River, northcentral Minnesota [abs.]: Transferring Models to Users, Denver, Colorado, November 4-9, 1990, American Water Resources Association, p. 1.

Stoner, J.D., 1991, National Water-Quality Assessment Program-Red River of the North: U.S. Geological Survey Open-File Report 91-151, 2 p.

Stoner, J.D., Brigham, M.E., and Cowdery, T.K., 1994, Water quality in surficial glacial-deposit aquifers in the Red River of the North drainage basin, Minnesota, North Dakota, and South Dakota [abs.]: Midwest Ground Water Conference, 39th, Bismarck, North Dakota, October 16-18, 1994, p. 15.

Stoner, J.D., Cowdery, T.K., and Puckett, L.J., 1997, Groundwater age dating and other tools used to assess land-use effects on water quality: U.S. Geological Water-Resources Investigations Report 97-4150, 6 p.

Stoner, J.D., and Lorenz, D.L., 1994, Environmental setting of the Red River of the North Basin, Minnesota, North Dakota, and South Dakota - framework for a regional water-quality assessment [abs.]: Minnesota Water '94, Managing Minnesota's Rivers and Watersheds, Minneapolis, Minnesota, April 21-22, 1994, p. 2-3.

Stoner, J.D., Lorenz, D.L., Goldstein, R.M., Brigham, M.E., and Cowdery, T.K., 1998, Water quality in the Red River of the North Basin, Minnesota, North Dakota, and South Dakota, 1992-95: U.S. Geological Survey Circular 1169, 33 p.

Stoner, J.D., Lorenz, D.L., Wiche, G.J., and Goldstein, R.M., 1993, Red River of the North Basin, Minnesota, North Dakota, and South Dakota: Water Resources Research Bulletin, v. 29, no. 4, p. 575-615.

Straka, G.C., and Schneider, R., 1957, Graphs of ground-water levels in Minnesota through 1956: Minnesota Department Conservation, Division of Waters Bulletin 9, 42 p.

Theis, C.V., 1935, The relation between the lowering of the piezometric surface and the rate and duration of discharge of a well using ground-water storage: Transactions of the American Geophysical Union, v. 16, pt. 2, p. 519-524.

Tornes, L.H., and Brigham, M.E., 1994, Agricultural chemicals in streams of the Red River of the North drainage basin [abs.]: Minnesota Water '94, Managing Minnesota's Rivers and Watersheds, Minneapolis, Minnesota, April 21-22, 1994, p. 3.

Tornes, L.H., Puckett, L.J., and Stoner, J.D., 1996, Variations in nitrate nitrogen concentrations beneath a riparian wetland in Minnesota [abs.], in Puckett L.J., and Triska, J.F., eds., U.S. Geological Survey Nitrogen-Cycling Workshop, Denver, Colorado, October 30-November 2, 1995: U.S. Geological Survey Open-File 96-477, p. 45.

Ulteig Engineers, Inc., 1987, Report on test well drilling in the Buffalo aquifer for the city of Moorhead, Minnesota: Consultant report, $11 \mathrm{p}$. 


\section{Ground-Water Availability from Surficial Aquifers in the Red River of the North Basin, Minnesota}

U.S. Department of the Interior, Bureau of Reclamation, 2005, Executive summary — draft report on Red River Valley water needs and options: U.S. Department of the Interior, Bureau of Reclamation, Dakotas Area Office, 25 p.

U.S. Environmental Protection Agency, 1986, Quality criteria for water 1986: EPA-440/5-86-001, various pagination.

Williams-Sether, T., 2004, River gain and loss studies for the Red River of the North Basin, North Dakota and Minnesota: U.S. Geological Survey Open-File Report 2004-1076, 21 p.

Winter, T.C., 1974, The natural quality of ground water in Minnesota: Minnesota Department of Natural Resources Bulletin 26, $25 \mathrm{p}$.

Winter, T.C., Bidwell, L.E., and Maclay, R.W., 1969, Water resources of the Otter Tail River watershed, west-central Minnesota: U.S. Geological Survey Hydrologic Investigations Atlas HA-296, 4 sheets, scale 1:250,000.
Winter, T.C., Bidwell, L.E., and Maclay, R.W., 1970, Water resources of the Wild Rice River watershed, northwestern Minnesota: U.S. Geological Survey Hydrologic Investigations Atlas HA-339, 4 sheets, scale 1:250,000.

Winter, T.C., Maclay, R.W., and Pike G.M., 1967, Water resources of the Roseau River watershed, northwestern Minnesota: U.S. Geological Survey Hydrologic Investigations Atlas HA-241, 3 sheets, scale 1:250,000.

Wolf, R.J., 1981, Hydrogeology of the Buffalo aquifer, Clay and Wilkin Counties, west-central Minnesota: U.S. Geological Survey Water-Resources Investigations Report 81-4, $83 \mathrm{p}$.

Wright, H.E., Jr., 1962, Role of the Wadena lobe in the Wisconsin glaciation of Minnesota: Geological Society of America Bulletin, v. 73, p. 73-100. 


\section{Appendix}

The information summarized in this report was compiled from numerous studies, reports, fact sheets, maps, hydrologic atlases, and abstracts. Although all of the selected references have provided valuable information regarding general geology and hydrogeology of the Red River of the North Basin, particular resources provided pertinent information that was specific to the individual, nine surficial aquifers that are the focus of this report. Tables A1 and A2 are included to assist others in obtaining additional information related to this study and for future ground-water and hydrogeology studies conducted within the Red River of the North Basin. Tables A1 and A2 are summary matrices of the particular references cited for the nine selected surficial aquifers (table A1) and general references for the Red River of the North Basin (table A2). Although the references listed in tables A1 and A2 will provide the information compiled for this report, the tables and the cited references are not comprehensive lists of all of the sources of information pertaining to the selected surficial aquifers and the hydrogeology of the Red River of the North Basin.

References listed in table A1 for each of the surficial aquifers were divided (and noted as such) into two categories, primary and secondary. In general, the primary references contained the most recently published and (or) most comprehensive information. Secondary references provided important historical data, regional-based information not specific to a particular aquifer, and minor or less detailed information. The 12 column headings of tables A1 and A2 (for example, Aquifer extent, Geologic description, and so forth) were selected to most accurately characterize and describe the aquifers and water resources within the Red River of the North Basin and used to identify the information contained within the cited references.

Although estimates of the surficial aquifer's water budgets used to evaluate the availability of ground water are presented in table 2, table A3 is a more extensive list of available waterbudget information. Water-budget estimates in table A3, compiled from individual studies, were produced by (1) steady-state aquifer simulations; (2) water budgets that were based on precipitation data, hydrograph analysis, and infiltration capacities of soils; and (3) known recharge and discharge components. When available and applicable, multiple water budgets have been included and cited in table A 3 for the surficial aquifers by the various methods used and (or) by authors. The objective of including the multiple estimates is to provide a comparative assessment of the estimation methods used for each aquifer and for comparison to the other surficial aquifers included in this study.

Similar to water budgets in table 2, water-budget estimates in table A3 have been converted to millions of gallons per year (Mgal/yr) for comparative purposes. Estimates of mean net areal recharge from hydrograph analysis and infiltration capacity of soils may differ from values reported in the original studies. Many of the water-budget components for the aquifers were not determined or were not available. Additional information regarding the surficial aquifers' sources and losses of water may exist that were not presented in table A3. If specific information regarding an aquifer's water budget and the methods of determination are necessary, the reader is encouraged to review the cited studies. 


\begin{tabular}{|c|c|c|c|c|c|c|c|c|c|c|c|c|}
\hline \multirow[b]{2}{*}{ Reference } & \multicolumn{12}{|c|}{ Type of information } \\
\hline & $\begin{array}{c}\text { Aquifer } \\
\text { extent }\end{array}$ & $\begin{array}{l}\text { Geologic } \\
\text { descrip- } \\
\text { tion }\end{array}$ & $\begin{array}{c}\text { Aquifer } \\
\text { pro- } \\
\text { perties }\end{array}$ & $\begin{array}{l}\text { Water- } \\
\text { quality } \\
\text { data }\end{array}$ & $\begin{array}{c}\text { Ground- } \\
\text { water } \\
\text { storage }\end{array}$ & $\begin{array}{l}\text { Ground/ } \\
\text { surface- } \\
\text { water } \\
\text { inter- } \\
\text { actions }\end{array}$ & $\begin{array}{l}\text { Stream } \\
\text { discharge } \\
\text { measure- } \\
\text { ments }\end{array}$ & $\begin{array}{l}\text { Ground- } \\
\text { water } \\
\text { flow } \\
\text { simula- } \\
\text { tions }\end{array}$ & $\begin{array}{c}\text { Recharge/ } \\
\text { discharge } \\
\text { sources }\end{array}$ & $\begin{array}{l}\text { Water- } \\
\text { budget } \\
\text { data/ } \\
\text { simula- } \\
\text { tions }\end{array}$ & $\begin{array}{c}\text { Historical } \\
\text { ground- } \\
\text { water use }\end{array}$ & $\begin{array}{l}\text { Theoretical } \\
\text { well yields }\end{array}$ \\
\hline
\end{tabular}

Lorenz and Stoner, 1996 Maclay and others, 1965

Maclay and others, 1967

Lindgren, 1996

Maclay and others, 1972

Schiner, 1960

Schiner, 1963

\section{Beach Ridge aquifers}

\section{Middle River surficial aquifer}

\begin{tabular}{|c|c|c|c|c|c|c|c|c|c|}
\hline -- & $\mathrm{x}$ & -- & -- & -- & -- & -- & -- & -- & -- \\
\hline$x$ & $\mathrm{x}$ & $\mathrm{x}$ & $\mathrm{x}$ & $\mathrm{x}$ & -- & $\mathrm{X}$ & $\mathrm{x}$ & $\mathrm{x}$ & $\mathrm{X}$ \\
\hline$\bullet$ & • & -- & -- & -- & • & • & • & -- & • \\
\hline$\bullet$ & $\bullet$ & -- & -- & -- & -- & -- & -- & -- & $\bullet$ \\
\hline & • & -- & • & • & -- & • & • & • & -- \\
\hline
\end{tabular}


Table A1. Specific references cited for selected surficial aquifers in Red River of the North Basin, Minnesota.-Continued

[x, primary reference; $\bullet$, secondary reference; --, information not available]

\begin{tabular}{|c|c|c|c|c|c|c|c|c|c|c|c|c|}
\hline \multirow[b]{2}{*}{ Reference } & \multicolumn{12}{|c|}{ Type of information } \\
\hline & $\begin{array}{c}\text { Aquifer } \\
\text { extent }\end{array}$ & $\begin{array}{l}\text { Geologic } \\
\text { descrip- } \\
\text { tion }\end{array}$ & $\begin{array}{c}\text { Aquifer } \\
\text { pro- } \\
\text { perties }\end{array}$ & $\begin{array}{l}\text { Water- } \\
\text { quality } \\
\text { data }\end{array}$ & $\begin{array}{c}\text { Ground- } \\
\text { water } \\
\text { storage }\end{array}$ & $\begin{array}{c}\text { Ground/ } \\
\text { surface- } \\
\text { water } \\
\text { inter- } \\
\text { actions }\end{array}$ & $\begin{array}{c}\text { Stream } \\
\text { discharge } \\
\text { measure- } \\
\text { ments }\end{array}$ & $\begin{array}{l}\text { Ground- } \\
\text { water } \\
\text { flow } \\
\text { simula- } \\
\text { tions }\end{array}$ & $\begin{array}{c}\text { Recharge/ } \\
\text { discharge } \\
\text { sources }\end{array}$ & $\begin{array}{c}\text { Water- } \\
\text { budget } \\
\text { data/ } \\
\text { simula- } \\
\text { tions }\end{array}$ & $\begin{array}{l}\text { Historical } \\
\text { ground- } \\
\text { water use }\end{array}$ & $\begin{array}{l}\text { Theoretical } \\
\text { well yields }\end{array}$ \\
\hline
\end{tabular}

\section{Anderson, 1980}

Miller, 1982

Minnesota Department of Natural Resources, 2000

Minnesota Department of Natural Resources, 2002

Minnesota Geological Survey, 1995

Minnesota Geological Survey, 1999

Hobbs and Goebel, 1982

Miller, 1981

Anderson, 1980

Minnesota Department of Natural Resources, 2002

Minnesota Geological Survey, 1999

Reeder, 1972

Hobbs and Goebel, 1982

Reeder, 1969

Ruhl, 1997

Winter and others, 1969

\section{Lindgren, 2002}

Lindholm, 1970

Minnesota Department of Natural Resources, 2002

Minnesota Geological Survey, 1999

Myette, 1984

Hobbs and Goebel, 1982

Myette, 1982

Wright, 1962
Pelican River sand-plain aquifer

$\begin{array}{cccc}-- & x & -- & - \\ x & x & -- & - \\ -- & x & -- & - \\ -- & x & -- & \\ -- & -- & -- & - \\ -- & -- & -- & - \\ -- & -- & -- & - \\ - & - & -- & -\end{array}$

Otter Tail surficial aquifer

$$
\begin{array}{cc}
-- & \mathrm{x} \\
-- & \mathrm{x} \\
-- & -- \\
\mathrm{x} & \mathrm{x} \\
& \\
-- & -- \\
- & \bullet \\
-- & \bullet \\
\hline
\end{array}
$$

Wadena surficial aquifer

\begin{tabular}{ll}
$\mathrm{x}$ & $\mathrm{x}$ \\
$\mathrm{x}$ & $\mathrm{x}$ \\
$\mathrm{x}$ & $\mathrm{x}$ \\
-- & $\mathrm{x}$ \\
$\mathrm{x}$ & $\mathrm{x}$ \\
& \\
\hline & -- \\
-- & -- \\
-- & -
\end{tabular}

$\begin{array}{ll}-- & - \\ -- & - \\ -- & - \\ \mathrm{X} & - \\ -- & - \\ -- & \\ -- & \\ -- & \end{array}$

--
--
--
--
--
--
-
-
-

-

$\begin{array}{llllllllll}\mathrm{x} & -- & \mathrm{x} & \mathrm{x} & \mathrm{x} & \mathrm{x} & \mathrm{x} & \mathrm{x} & \mathrm{x} & \mathrm{x} \\ \mathrm{x} & \mathrm{x} & -- & \mathrm{x} & -- & \mathrm{x} & \mathrm{x} & \mathrm{x} & \mathrm{x} & \mathrm{x} \\ -- & \mathrm{x} & -- & \mathrm{x} & -- & -- & \mathrm{x} & -- & -- & - \\ -- & -- & -- & -- & -- & -- & -- & -- & -- & - \\ \mathrm{x} & \mathrm{x} & -- & -- & -- & -- & -- & -- & -- & -- \\ & & & & -- & - & & & & - \\ -- & -- & -- & -- & -- & -- & -- & -- & -- & - \\ -- & - & -- & -- & -- & -- & -- & -- & -- & - \\ -- & -- & -- & -- & -- & -- & -- & -- & -- & -\end{array}$


[x, primary reference; $\bullet$, secondary reference; --, information not available $]$

\begin{tabular}{|c|c|c|c|c|c|c|c|c|c|c|c|}
\hline \multirow[b]{2}{*}{ Reference } & \multicolumn{11}{|c|}{ Type of information } \\
\hline & $\begin{array}{c}\text { Aquifer } \\
\text { extent }\end{array}$ & $\begin{array}{l}\text { Geologic } \\
\text { descrip- } \\
\text { tion }\end{array}$ & $\begin{array}{l}\text { Aquifer } \\
\text { pro- } \\
\text { perties }\end{array}$ & $\begin{array}{l}\text { Water- } \\
\text { quality } \\
\text { data }\end{array}$ & $\begin{array}{l}\text { Ground- } \\
\text { water } \\
\text { storage }\end{array}$ & $\begin{array}{l}\text { Ground/ } \\
\text { surface- } \\
\text { water } \\
\text { inter- } \\
\text { actions }\end{array}$ & $\begin{array}{l}\text { Stream } \\
\text { discharge } \\
\text { measure- } \\
\text { ments }\end{array}$ & $\begin{array}{l}\text { Ground- } \\
\text { water } \\
\text { flow } \\
\text { simula- } \\
\text { tions }\end{array}$ & $\begin{array}{l}\text { Recharge/ } \\
\text { discharge } \\
\text { sources }\end{array}$ & $\begin{array}{l}\text { Water- } \\
\text { budget } \\
\text { data/ } \\
\text { simula- } \\
\text { tions }\end{array}$ & $\begin{array}{c}\text { Historical } \\
\text { ground- } \\
\text { wateruse }\end{array}$ \\
\hline
\end{tabular}

\section{Helgesen, 1977}

Minnesota Department of Natural Resources, 2002

Minnesota Geological Survey, 1999

Stark and others, 1994

Hobbs and Goebel, 1982

Ruhl, 1995

Stark and others, 1991

Baker and Kuehnast, 1978

Baker and others, 1979

Hobbs and Goebel, 1982

Pineland Sands surficial aquifer


Table A2. General references cited for Red River of the North Basin, Minnesota.

[x, information available; --, information not available]

\begin{tabular}{|c|c|c|c|c|c|c|c|c|c|c|c|c|}
\hline \multirow[b]{2}{*}{ Reference } & \multicolumn{12}{|c|}{ Type of information } \\
\hline & $\begin{array}{c}\text { Aquifer } \\
\text { extent }\end{array}$ & $\begin{array}{l}\text { Geologic } \\
\text { description }\end{array}$ & $\begin{array}{l}\text { Aquifer } \\
\text { properties }\end{array}$ & $\begin{array}{l}\text { Water- } \\
\text { quality } \\
\text { data }\end{array}$ & $\begin{array}{l}\text { Ground } \\
\text { water } \\
\text { storage }\end{array}$ & $\begin{array}{c}\text { Ground-/ } \\
\text { surface-water } \\
\text { interactions }\end{array}$ & $\begin{array}{c}\text { Stream } \\
\text { discharge } \\
\text { measure- } \\
\text { ments }\end{array}$ & $\begin{array}{c}\text { Ground- } \\
\text { water flow } \\
\text { simulations }\end{array}$ & $\begin{array}{l}\text { Recharge/ } \\
\text { discharge } \\
\text { sources }\end{array}$ & $\begin{array}{l}\text { Water- } \\
\text { budget } \\
\text { data/simu- } \\
\text { lations }\end{array}$ & $\begin{array}{l}\text { Historical } \\
\text { ground- } \\
\text { water use }\end{array}$ & $\begin{array}{l}\text { Theoretical } \\
\text { well yields }\end{array}$ \\
\hline Anderson and Stoner, 1989 & -- & -- & $\mathrm{x}$ & $\mathrm{x}$ & -- & $\mathrm{x}$ & -- & -- & $\mathrm{x}$ & -- & -- & -- \\
\hline Bidwell and others, 1970 & $\mathrm{x}$ & $\mathrm{x}$ & $\mathrm{x}$ & $\mathrm{x}$ & -- & $\mathrm{x}$ & $\mathrm{x}$ & -- & $\mathrm{x}$ & $\mathrm{x}$ & $\mathrm{x}$ & $\mathrm{x}$ \\
\hline Cotter and Bidwell, 1966 & $\mathrm{x}$ & $\mathrm{x}$ & $\mathrm{x}$ & $\mathrm{x}$ & -- & $\mathrm{x}$ & $\mathrm{x}$ & -- & $\mathrm{x}$ & $\mathrm{x}$ & $\mathrm{x}$ & $\mathrm{x}$ \\
\hline Cotter and others, 1966 & $\mathrm{x}$ & $\mathrm{x}$ & $\mathrm{x}$ & $\mathrm{x}$ & -- & $\mathrm{x}$ & $\mathrm{x}$ & -- & $\mathrm{x}$ & $\mathrm{x}$ & $\mathrm{x}$ & $\mathrm{x}$ \\
\hline Cowdery, 1995 & -- & -- & -- & $\mathrm{x}$ & -- & -- & -- & -- & -- & -- & -- & -- \\
\hline Cowdery, 1997 & $\mathrm{x}$ & $\mathrm{x}$ & -- & $\mathrm{x}$ & -- & -- & -- & -- & -- & -- & -- & -- \\
\hline Cowdery, 1998 & $\mathrm{x}$ & $\mathrm{x}$ & -- & $\mathrm{x}$ & -- & $\mathrm{x}$ & $\mathrm{x}$ & -- & $\mathrm{x}$ & -- & -- & -- \\
\hline Delin, 1986 & $\mathrm{x}$ & $\mathrm{x}$ & $\mathrm{x}$ & $\mathrm{x}$ & -- & $\mathrm{x}$ & -- & $\mathrm{x}$ & $\mathrm{x}$ & $\mathrm{x}$ & $\mathrm{x}$ & $\mathrm{x}$ \\
\hline Delin, 1995 & $\mathrm{x}$ & $\mathrm{x}$ & $\mathrm{x}$ & -- & -- & -- & -- & -- & -- & -- & -- & -- \\
\hline Larson and others, 1975 & $\mathrm{x}$ & $\mathrm{x}$ & $\mathrm{x}$ & -- & -- & $\mathrm{x}$ & -- & $\mathrm{x}$ & $\mathrm{x}$ & $\mathrm{x}$ & -- & -- \\
\hline Lindholm, 1980 & $\mathrm{x}$ & $\mathrm{x}$ & $\mathrm{x}$ & $\mathrm{x}$ & -- & $\mathrm{x}$ & $\mathrm{x}$ & $\mathrm{x}$ & $\mathrm{x}$ & -- & -- & $\mathrm{x}$ \\
\hline $\begin{array}{l}\text { Lindholm and Norvitch, } \\
1976\end{array}$ & $\mathrm{x}$ & $\mathrm{x}$ & -- & $\mathrm{x}$ & -- & -- & -- & -- & -- & -- & $\mathrm{x}$ & $\mathrm{x}$ \\
\hline Lindholm and others, 1972 & $\mathrm{x}$ & $\mathrm{x}$ & $\mathrm{x}$ & $\mathrm{x}$ & -- & $\mathrm{x}$ & $\mathrm{x}$ & -- & $\mathrm{x}$ & $\mathrm{x}$ & $\mathrm{x}$ & $\mathrm{x}$ \\
\hline Lorenz, 1992 & $\mathrm{x}$ & -- & -- & -- & -- & -- & -- & -- & $\mathrm{x}$ & -- & -- & -- \\
\hline Lorenz and Stoner, 1996 & $\mathrm{x}$ & -- & -- & $\mathrm{x}$ & -- & -- & -- & -- & -- & -- & -- & -- \\
\hline Maclay and others, 1968 & $\mathrm{x}$ & $\mathrm{x}$ & $\mathrm{x}$ & $\mathrm{x}$ & -- & $\mathrm{x}$ & $\mathrm{x}$ & -- & $\mathrm{x}$ & $\mathrm{x}$ & $\mathrm{x}$ & $\mathrm{x}$ \\
\hline Magner and others, 1997 & $\mathrm{x}$ & $\mathrm{x}$ & $\mathrm{x}$ & & -- & -- & -- & -- & -- & -- & -- & -- \\
\hline Puckett and Cowdery, 2002 & $\mathrm{x}$ & $\mathrm{x}$ & -- & $\mathrm{x}$ & -- & -- & -- & -- & -- & -- & -- & -- \\
\hline Puckett and others, 1999 & $\mathrm{x}$ & $\mathrm{x}$ & -- & $\mathrm{x}$ & -- & -- & -- & -- & -- & -- & -- & -- \\
\hline Ruhl, 1996 & -- & -- & -- & $\mathrm{x}$ & -- & -- & -- & -- & -- & -- & -- & -- \\
\hline Stoner, 1991 & $\mathrm{x}$ & $\mathrm{x}$ & -- & $\mathrm{x}$ & -- & $\mathrm{x}$ & -- & -- & $\mathrm{x}$ & -- & $\mathrm{x}$ & -- \\
\hline Stoner and others, 1993 & $\mathrm{x}$ & $\mathrm{x}$ & $\mathrm{x}$ & $\mathrm{x}$ & -- & -- & -- & -- & -- & -- & -- & $\mathrm{x}$ \\
\hline Stoner and others, 1997 & $\mathrm{x}$ & -- & -- & $\mathrm{x}$ & -- & -- & -- & $\mathrm{x}$ & $\mathrm{x}$ & -- & -- & -- \\
\hline Stoner and others, 1998 & $\mathrm{x}$ & -- & -- & $\mathrm{x}$ & -- & $\mathrm{x}$ & $\mathrm{x}$ & -- & $\mathrm{x}$ & -- & -- & -- \\
\hline Theis, 1935 & -- & -- & $\mathrm{x}$ & -- & $\mathrm{x}$ & -- & -- & -- & -- & -- & -- & $\mathrm{x}$ \\
\hline Winter and others, 1967 & $\mathrm{x}$ & $\mathrm{x}$ & $\mathrm{x}$ & $\mathrm{x}$ & -- & $\mathrm{x}$ & $\mathrm{x}$ & -- & $\mathrm{x}$ & $\mathrm{x}$ & $\mathrm{x}$ & $\mathrm{x}$ \\
\hline Winter and others, 1970 & $\mathrm{x}$ & $\mathrm{x}$ & $\mathrm{x}$ & $\mathrm{x}$ & -- & $\mathrm{x}$ & $\mathrm{x}$ & -- & $\mathrm{x}$ & $\mathrm{x}$ & $\mathrm{x}$ & $\mathrm{x}$ \\
\hline
\end{tabular}


[Mgal, millions of gallons; $\mathrm{mi}^{2}$, square miles; in/yr, inches per year; Mgal/yr, millions of gallons per year; --, data not available; $\mathrm{ft}^{3} / \mathrm{s}$, cubic feet per second]

\begin{tabular}{|c|c|c|c|c|c|c|c|c|c|c|}
\hline & & & & & & & Sour & s of water to aqu & iifer & \\
\hline $\begin{array}{l}\text { Aquifer name } \\
\text { (reference) }\end{array}$ & $\begin{array}{l}\text { Method of } \\
\text { determination }\end{array}$ & $\begin{array}{l}\text { Maximum } \\
\text { aquifer } \\
\text { storage }^{1} \\
\text { (Mgal) }\end{array}$ & $\begin{array}{l}\text { Area of } \\
\text { aquifer } \\
\left(\mathrm{mi}^{2}\right)\end{array}$ & $\begin{array}{l}\text { Year of areal } \\
\text { recharge } \\
\text { data }^{2} \\
\text { (dimension- } \\
\text { less) }\end{array}$ & $\begin{array}{l}\text { Mean areal } \\
\text { recharge } \\
\text { rate }^{2} \\
\text { [range] } \\
\text { (in/yr) }\end{array}$ & $\begin{array}{l}\text { areal } \\
\text { recharge to } \\
\text { mean } \\
\text { annual } \\
\text { precipi- } \\
\text { tation }\end{array}$ & $\begin{array}{c}\text { Mean areal } \\
\text { recharge } \\
\text { (area } x \text { rate) } \\
\text { (Mgal/yr) }\end{array}$ & $\begin{array}{c}\text { Flow from } \\
\text { surface water } \\
\text { (Mgal/yr) }\end{array}$ & $\begin{array}{c}\text { Flow across } \\
\text { boundaries } \\
\text { (Mgal/yr) }\end{array}$ & $\begin{array}{c}\text { Total } \\
\text { sources } \\
\text { (inflows) of } \\
\text { water to } \\
\text { the aquifer } \\
\text { (Mgal/yr) }\end{array}$ \\
\hline $\begin{array}{l}\text { Buffalo aquifer } \\
\text { (Wolf, 1981) }\end{array}$ & $\begin{array}{l}\text { hydrograph } \\
\text { analysis }\end{array}$ & 270,000 & 66 & $1977-78$ & $\begin{array}{c}4.1 \\
{[2.4-8.8]}\end{array}$ & 20 & 4,700 & -- & -- & 4,700 \\
\hline $\begin{array}{l}\text { Buffalo aquifer } \\
\text { (Schoenberg, 1998) }\end{array}$ & $\begin{array}{l}\text { hydrograph } \\
\text { analysis }\end{array}$ & 270,000 & 25 & 1993 & $\begin{array}{l}4.8 \\
{[3.6-5.5]}\end{array}$ & 23 & 407 & 3,300 & 0 & 3,707 \\
\hline Beach Ridge aquifers & -- & -- & -- & -- & -- & -- & -- & -- & -- & -- \\
\hline $\begin{array}{l}\text { Middle River surficial aquifer } \\
\text { (Maclay and others, 1965) }\end{array}$ & $\begin{array}{l}\text { infiltration } \\
\text { capacity of soils }\end{array}$ & 4,600 & 22 & 1962 & $\begin{array}{c}3 \\
{[2-4]}\end{array}$ & 16 & 1,100 & -- & 27.0 & 1,127 \\
\hline $\begin{array}{l}\text { Two Rivers surficial aquifer } \\
\text { (Maclay and others, 1965, 1967) }\end{array}$ & $\begin{array}{l}\text { infiltration } \\
\text { capacity of soils }\end{array}$ & 400,000 & 146 & 1962 & $\begin{array}{c}2.5 \\
{[1-4]}\end{array}$ & 11 & 6,300 & -- & 200 & 6,500 \\
\hline \multirow[t]{4}{*}{$\begin{array}{l}\text { Pelican River sand-plain aquifer } \\
\text { (Miller, 1982) }\end{array}$} & $\begin{array}{l}\text { hydrograph } \\
\text { analysis }\end{array}$ & 300,000 & 195 & 1979 & $\begin{array}{c}4.9 \\
{[3.7-6.1]}\end{array}$ & 22 & 17,000 & -- & 0 & 17,000 \\
\hline & $\begin{array}{l}\text { hydrograph } \\
\text { analysis }\end{array}$ & 300,000 & 195 & 1980 & $\begin{array}{c}4.5 \\
{[3.1-5.9]}\end{array}$ & 20 & 15,000 & -- & 0 & 15,000 \\
\hline & $\begin{array}{l}\text { steady-state } \\
\text { "Detroit Lakes" } \\
\text { simulation }\end{array}$ & 300,000 & 195 & -- & -- & -- & 5,500 & 1,900 & 1,500 & 8,900 \\
\hline & $\begin{array}{l}\text { steady-state } \\
\text { "Scrambler" simulation }\end{array}$ & 300,000 & 195 & -- & -- & -- & 3,800 & 1,100 & -- & 4,900 \\
\hline $\begin{array}{l}\text { Otter Tail surficial aquifer } \\
\text { (Reeder, 1972) }\end{array}$ & $\begin{array}{l}\text { hydrograph } \\
\text { analysis }\end{array}$ & 500,000 & 510 & 1969 & $\begin{array}{c}5.5 \\
{[3-6]}\end{array}$ & 27 & 49,000 & 0 & 2,000 & 51,000 \\
\hline
\end{tabular}


Table A3. Comprehensive list of estimated water budgets for selected surficial aquifers in Red River of the North Basin, Minnesota.-Continued

[Mgal, millions of gallons; $\mathrm{mi}^{2}$, square miles; in/yr, inches per year; Mgal/yr, millions of gallons per year; --, data not available; $\mathrm{ft}^{3} / \mathrm{s}$, cubic feet per second]

\begin{tabular}{|c|c|c|c|c|c|c|c|c|c|c|}
\hline \multirow[b]{2}{*}{$\begin{array}{l}\text { Aquifer name } \\
\text { (reference) }\end{array}$} & \multirow[b]{2}{*}{$\begin{array}{c}\text { Method of } \\
\text { determination }\end{array}$} & \multirow[b]{2}{*}{$\begin{array}{l}\text { Maximum } \\
\text { aquifer } \\
\text { storage }^{1} \\
\text { (Mgal) }\end{array}$} & \multirow[b]{2}{*}{$\begin{array}{l}\text { Area of } \\
\text { aquifer } \\
\left(\mathrm{mi}^{2}\right)\end{array}$} & \multirow[b]{2}{*}{$\begin{array}{c}\text { Year of areal } \\
\text { recharge } \\
\text { data }^{2} \\
\text { (dimension- } \\
\text { less) }\end{array}$} & \multirow[b]{2}{*}{$\begin{array}{l}\text { Mean areal } \\
\text { recharge } \\
\text { rate }^{2} \\
\text { [range] } \\
\text { (in/yr) }\end{array}$} & \multirow{2}{*}{$\begin{array}{l}\text { Percentage } \\
\text { of mean } \\
\text { areal } \\
\text { recharge to } \\
\text { mean } \\
\text { annual } \\
\text { precipi- } \\
\text { tation }^{3}\end{array}$} & \multicolumn{3}{|c|}{ Sources of water to aquifer } & \multirow[b]{2}{*}{$\begin{array}{l}\text { Total } \\
\text { sources } \\
\text { (inflows) of } \\
\text { water to } \\
\text { the aquifer } \\
\text { (Mgal/yr) }\end{array}$} \\
\hline & & & & & & & $\begin{array}{l}\text { Mean areal } \\
\text { recharge } \\
\text { (area } x \text { rate) } \\
\text { (Mgal/yr) }\end{array}$ & $\begin{array}{l}\text { Flow from } \\
\text { surface water } \\
\text { (Mgal/yr) }\end{array}$ & $\begin{array}{c}\text { Flow across } \\
\text { boundaries } \\
\text { (Mgal/yr) }\end{array}$ & \\
\hline $\begin{array}{l}\text { Wadena surficial aquifer } \\
\text { (Lindholm, 1970) }\end{array}$ & $\begin{array}{l}\text { hydrograph } \\
\text { analysis }\end{array}$ & 150,000 & 397 & 1967 & 8 & 38 & 55,000 & -- & -- & 55,000 \\
\hline & $\begin{array}{l}\text { regional precipitation } \\
\text { data and hydrograph }\end{array}$ & 60,453 & 160 & $1934-67$ & -- & -- & 53,000 & 16,000 & 300 & 69,300 \\
\hline \multirow[t]{3}{*}{$\begin{array}{l}\text { Wadena surficial aquifer } \\
\text { (Lindgren, 2002) }\end{array}$} & $\begin{array}{l}\text { hydrograph } \\
\text { analysis }\end{array}$ & 150,000 & 397 & 1998 & $\begin{array}{c}13.9 \\
{[6-23]}\end{array}$ & 65 & 96,000 & -- & -- & 96,000 \\
\hline & $\begin{array}{l}\text { hydrograph } \\
\text { analysis }\end{array}$ & 150,000 & 397 & 1999 & $\begin{array}{c}11.5 \\
{[6.2-17.3]}\end{array}$ & 54 & 79,000 & -- & -- & 79,000 \\
\hline & $\begin{array}{l}\text { numerical (regional) } \\
\text { steady-state simulation }\end{array}$ & 150,000 & 397 & -- & -- & -- & 67,000 & 1,000 & 24,000 & 92,000 \\
\hline $\begin{array}{l}\text { Leaf River area } \\
\text { (Wadena surficial aquifer- } \\
\text { Lindgren, 2002) }\end{array}$ & $\begin{array}{l}\text { hydrograph } \\
\text { analysis }\end{array}$ & 150,000 & 397 & 1998-99 & $\begin{array}{c}15.5 \\
{[10.6-23]}\end{array}$ & 73 & 107,000 & -- & -- & 107,000 \\
\hline \multirow[t]{5}{*}{$\begin{array}{l}\text { Pineland Sands surficial aquifer } \\
\text { (Helgesen, 1977) }\end{array}$} & $\begin{array}{l}\text { hydrograph } \\
\text { analysis }\end{array}$ & $1,000,000$ & 996 & $1971-76$ & 5.1 & 26 & 88,000 & -- & 11,000 & 99,000 \\
\hline & steady-state simulation & $1,000,000$ & 996 & -- & -- & -- & 58,000 & 6,000 & 6,000 & 70,000 \\
\hline & steady-state simulation & $1,000,000$ & 996 & -- & -- & -- & 58,000 & 6,000 & 6,000 & 70,000 \\
\hline & steady-state simulation & $1,000,000$ & 996 & -- & -- & -- & 58,000 & 6,000 & 6,000 & 70,000 \\
\hline & steady-state simulation & $1,000,000$ & 996 & -- & -- & -- & 58,000 & 6,000 & 6,000 & 70,000 \\
\hline
\end{tabular}


[Mgal, millions of gallons; $\mathrm{mi}^{2}$, square miles; in/yr, inches per year; Mgal/yr, millions of gallons per year; --, data not available; $\mathrm{ft}^{3} / \mathrm{s}$, cubic feet per second]

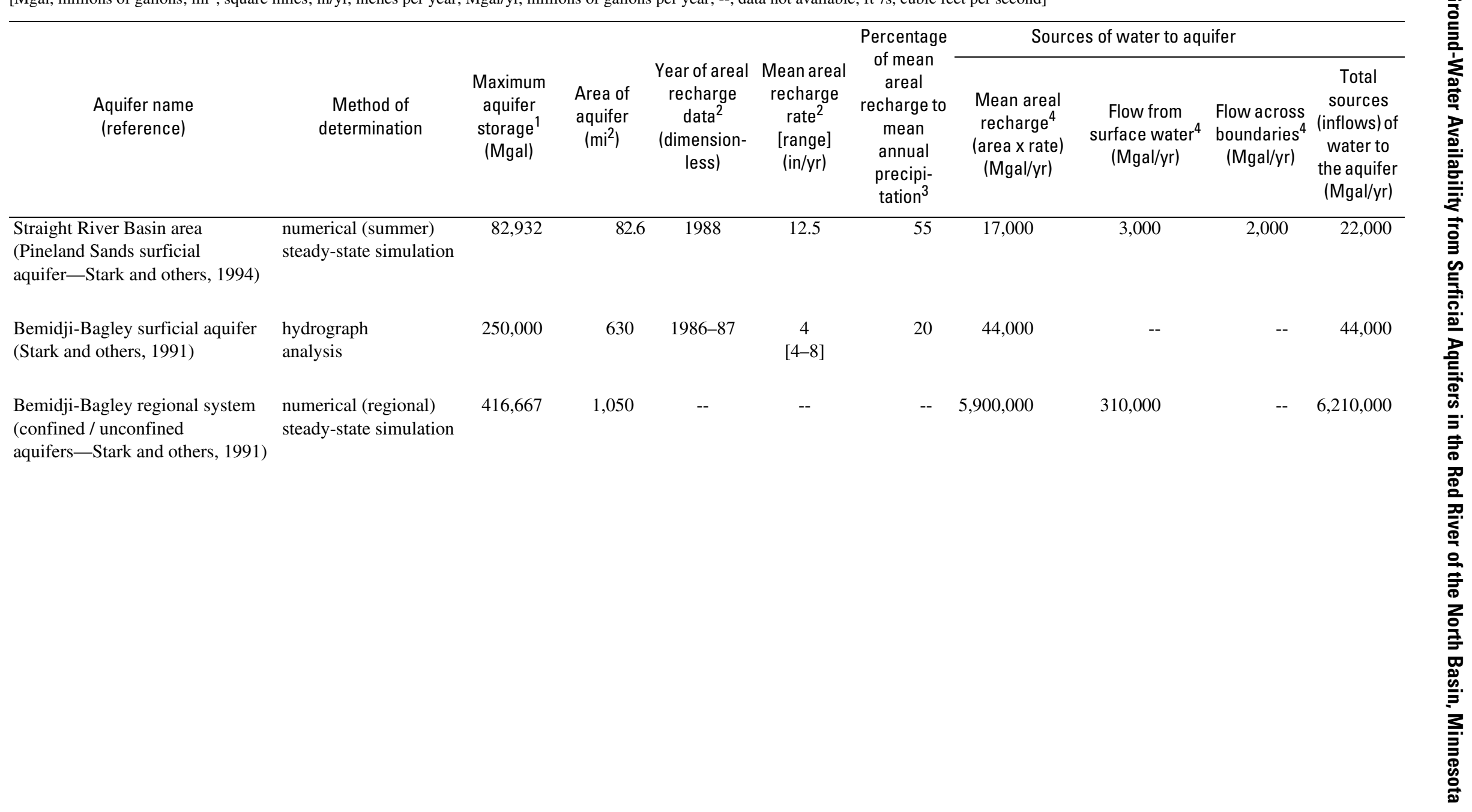


Table A3. Comprehensive list of estimated water budgets for selected surficial aquifers in Red River of the North Basin, Minnesota.-Continued

[Mgal, millions of gallons; $\mathrm{mi}^{2}$, square miles; in/yr, inches per year; Mgal/yr, millions of gallons per year; --, data not available; $\mathrm{ft}^{3} / \mathrm{s}$, cubic feet per second]

\begin{tabular}{|c|c|c|c|c|c|c|c|c|}
\hline \multirow[b]{2}{*}{$\begin{array}{l}\text { Aquifer name } \\
\text { (reference) }\end{array}$} & \multirow[b]{2}{*}{$\begin{array}{c}\text { Method of } \\
\text { determination }\end{array}$} & \multicolumn{4}{|c|}{ Losses of water from aquifer } & \multirow{2}{*}{$\begin{array}{l}\text { Total losses } \\
\text { (outflows) of } \\
\text { water from } \\
\text { aquifer } \\
\text { (Mgal/yr) }\end{array}$} & \multirow{2}{*}{$\begin{array}{l}\text { Differences } \\
\text { between } \\
\text { sources and } \\
\text { losses of water } \\
\text { in aquifer } \\
\text { (Mgal/yr) }\end{array}$} & \multirow[b]{2}{*}{ Explanation of estimated water budget } \\
\hline & & $\begin{array}{l}\text { Evapotrans- } \\
\text { piration }^{4} \\
\text { (Mgal/yr) }\end{array}$ & $\begin{array}{l}\text { Flow to surface } \\
\text { water } \\
\text { (Mgal/yr) }\end{array}$ & $\begin{array}{l}\text { Flow across } \\
\text { boundaries } \\
\text { (Mgal/yr) }\end{array}$ & $\begin{array}{l}\text { Withdrawals } \\
\text { by pumping } \\
\text { wells } \\
\text { (Mgal/yr) }\end{array}$ & & & \\
\hline $\begin{array}{l}\text { Buffalo aquifer } \\
\text { (Wolf, 1981) }\end{array}$ & $\begin{array}{l}\text { hydrograph } \\
\text { analysis }\end{array}$ & 0 & -- & -- & 408 & 408 & 4,292 & $\begin{array}{l}\text { Includes only net areal recharge and discharge } \\
\text { by wells (Minnesota Department of Natural } \\
\text { Resources, 2003). }\end{array}$ \\
\hline $\begin{array}{l}\text { Buffalo aquifer } \\
\text { (Schoenberg, 1998) }\end{array}$ & $\begin{array}{l}\text { hydrograph } \\
\text { analysis }\end{array}$ & 0 & -- & -- & 408 & 408 & 3,299 & $\begin{array}{l}\text { Losses include withdrawals by wells (Minnesota } \\
\text { Department of Natural Resources, 2003) and } \\
\text { exclude flow across boundaries (to Glacial Lake } \\
\text { Agassiz sediment and confined till). }\end{array}$ \\
\hline $\begin{array}{l}\text { Beach Ridge } \\
\text { aquifers }\end{array}$ & -- & -- & -- & -- & -- & -- & -- & No water-budget data available. \\
\hline $\begin{array}{l}\text { Middle River } \\
\text { surficial aquifer } \\
\text { (Maclay and others, } \\
\text { 1965) }\end{array}$ & $\begin{array}{l}\text { infiltration } \\
\text { capacity of soils }\end{array}$ & 0 & -- & -- & 26 & 26 & 1,101 & $\begin{array}{l}\text { Sources include areal recharge and flow across } \\
\text { boundaries; losses include withdrawals by wells } \\
\text { (Minnesota Department of Natural Resources, } \\
\text { 2003). }\end{array}$ \\
\hline $\begin{array}{l}\text { Two Rivers } \\
\text { surficial aquifer } \\
\text { (Maclay and others, } \\
\text { 1965, 1967) }\end{array}$ & $\begin{array}{l}\text { infiltration } \\
\text { capacity of soils }\end{array}$ & 0 & -- & -- & 440 & 440 & 6,060 & $\begin{array}{l}\text { Sources include areal recharge and flow across } \\
\text { boundaries; losses include withdrawals by wells } \\
\text { (Minnesota Department of Natural Resources, } \\
\text { 2003). }\end{array}$ \\
\hline \multirow[t]{3}{*}{$\begin{array}{l}\text { Pelican River sand- } \\
\text { plain aquifer } \\
\text { (Miller, 1982) }\end{array}$} & $\begin{array}{l}\text { hydrograph } \\
\text { analysis }\end{array}$ & 0 & -- & -- & -- & 0 & 17,000 & Includes only recharge sources. \\
\hline & $\begin{array}{l}\text { hydrograph } \\
\text { analysis }\end{array}$ & 0 & -- & -- & -- & 0 & 15,000 & Includes only recharge sources. \\
\hline & $\begin{array}{l}\text { steady-state } \\
\text { "Detroit Lakes" } \\
\text { simulation }\end{array}$ & 5,000 & 3,900 & -- & -- & 8,900 & 0 & Steady-state simulation. \\
\hline
\end{tabular}


Table A3. Comprehensive list of estimated water budgets for selected surficial aquifers in Red River of the North Basin, Minnesota.-Continued

[Mgal, millions of gallons; $\mathrm{mi}^{2}$, square miles; in/yr, inches per year; Mgal/yr, millions of gallons per year; --, data not available; $\mathrm{ft}^{3} / \mathrm{s}$, cubic feet per second]

\begin{tabular}{|c|c|c|c|c|c|c|c|c|}
\hline \multirow[b]{2}{*}{$\begin{array}{l}\text { Aquifer name } \\
\text { (reference) }\end{array}$} & \multirow[b]{2}{*}{$\begin{array}{l}\text { Method of } \\
\text { determination }\end{array}$} & \multicolumn{4}{|c|}{ Losses of water from aquifer } & \multirow{2}{*}{$\begin{array}{c}\text { Total losses } \\
\text { (outflows) of } \\
\text { water from } \\
\text { aquifer } \\
\text { (Mgal/yr) }\end{array}$} & \multirow{2}{*}{$\begin{array}{l}\text { Differences } \\
\text { between } \\
\text { sources and } \\
\text { losses of water } \\
\text { in aquifer } \\
\text { (Mgal/yr) }\end{array}$} & \multirow[b]{2}{*}{ Explanation of estimated water budget } \\
\hline & & $\begin{array}{l}\text { Evapotrans- } \\
\text { piration }{ }^{4} \\
\text { (Mgal/yr) }\end{array}$ & $\begin{array}{l}\text { Flow to surface } \\
\text { water }^{4} \\
(\mathrm{Mgal} / \mathrm{yr})\end{array}$ & $\begin{array}{c}\text { Flow across } \\
\text { boundaries } 4 \\
\text { (Mgal/yr) }\end{array}$ & $\begin{array}{l}\text { Withdrawals } \\
\text { by pumping } \\
\text { wells } \\
\text { (Mgal/yr) }\end{array}$ & & & \\
\hline $\begin{array}{l}\text { Pelican River sand- } \\
\text { plain aquifer- } \\
\text { Continued }\end{array}$ & $\begin{array}{l}\text { steady-state } \\
\text { "Scrambler" } \\
\text { simulation }\end{array}$ & 1,900 & 2,900 & 100 & -- & 4,900 & 0 & Steady-state simulation. \\
\hline $\begin{array}{l}\text { Otter Tail surficial } \\
\text { aquifer } \\
\text { (Reeder, 1972) }\end{array}$ & $\begin{array}{l}\text { hydrograph } \\
\text { analysis }\end{array}$ & 0 & -- & 2,000 & -- & 2,000 & 49,000 & $\begin{array}{l}\text { Includes only sources of water and losses of } \\
\text { water across boundaries to adjacent aquifers. }\end{array}$ \\
\hline \multirow[t]{2}{*}{$\begin{array}{l}\text { Wadena surficial } \\
\text { aquifer } \\
\text { (Lindholm, 1970) }\end{array}$} & $\begin{array}{l}\text { hydrograph } \\
\text { analysis }\end{array}$ & 0 & -- & -- & -- & 0 & 55,000 & Includes only net areal recharge. \\
\hline & $\begin{array}{l}\text { regional } \\
\text { precipitation } \\
\text { data and } \\
\text { hydrograph }\end{array}$ & 47,000 & 37,000 & 200 & -- & 84,200 & $-14,900$ & $14,900 \mathrm{Mgal} / \mathrm{yr}$ loss of aquifer storage. \\
\hline \multirow[t]{3}{*}{$\begin{array}{l}\text { Wadena surficial } \\
\text { aquifer } \\
\text { (Lindgren, 2002) }\end{array}$} & $\begin{array}{l}\text { hydrograph } \\
\text { analysis }\end{array}$ & 0 & -- & -- & 2,000 & 2,000 & 94,000 & $\begin{array}{l}\text { Includes only net areal recharge and actual } \\
\text { discharge to pumping wells of 2,000 Mgal/yr in } \\
1998 \text {. }\end{array}$ \\
\hline & $\begin{array}{l}\text { hydrograph } \\
\text { analysis }\end{array}$ & 0 & -- & -- & 2,000 & 2,000 & 77,000 & $\begin{array}{l}\text { Includes only net areal recharge and actual } \\
\text { discharge to pumping wells of } 2,000 \mathrm{Mgal} / \mathrm{yr} \text { in } \\
1998 .\end{array}$ \\
\hline & $\begin{array}{l}\text { numerical } \\
\text { (regional) } \\
\text { steady-state } \\
\text { simulation }\end{array}$ & 32,000 & 42,000 & 16,000 & 2,000 & 92,000 & 0 & $\begin{array}{l}\text { Surficial aquifer system only; simulated } \\
\text { pumping of } 6.45 \mathrm{ft}^{3} / \mathrm{s} \text { in } 1997-98 \text {; negligible } \\
\text { flow across boundaries to/from the adjacent } \\
\text { (confined) aquifer. }\end{array}$ \\
\hline
\end{tabular}


Table A3. Comprehensive list of estimated water budgets for selected surficial aquifers in Red River of the North Basin, Minnesota.-Continued

[Mgal, millions of gallons; $\mathrm{mi}^{2}$, square miles; in/yr, inches per year; Mgal/yr, millions of gallons per year; --, data not available; $\mathrm{ft}^{3} / \mathrm{s}$, cubic feet per second]

\begin{tabular}{|c|c|c|c|c|c|c|c|c|}
\hline \multirow[b]{2}{*}{$\begin{array}{l}\text { Aquifer name } \\
\text { (reference) }\end{array}$} & \multirow[b]{2}{*}{$\begin{array}{l}\text { Method of } \\
\text { determination }\end{array}$} & \multicolumn{4}{|c|}{ Losses of water from aquifer } & \multirow{2}{*}{$\begin{array}{c}\text { Total losses } \\
\text { (outflows) of } \\
\text { water from } \\
\text { aquifer } \\
\text { (Mgal/yr) }\end{array}$} & \multirow{2}{*}{$\begin{array}{l}\text { Differences } \\
\text { between } \\
\text { sources and } \\
\text { losses of water } \\
\text { in aquifer } \\
\text { (Mgal/yr) }\end{array}$} & \multirow[b]{2}{*}{ Explanation of estimated water budget } \\
\hline & & $\begin{array}{l}\text { Evapotrans- } \\
\text { piration } \\
\text { (Mgal/yr) }\end{array}$ & $\begin{array}{c}\text { Flow to surface } \\
\text { water }^{4} \\
\text { (Mgal/yr) }\end{array}$ & $\begin{array}{l}\text { Flow across } \\
\text { boundaries } \\
\text { (Mgal/yr) }\end{array}$ & $\begin{array}{l}\text { Withdrawals } \\
\text { by pumping } \\
\text { wells } \\
\text { (Mgal/yr) }\end{array}$ & & & \\
\hline $\begin{array}{l}\text { Leaf River area } \\
\text { (Wadena surficial } \\
\text { aquifer-Lindgren, } \\
\text { 2002) }\end{array}$ & $\begin{array}{l}\text { hydrograph } \\
\text { analysis }\end{array}$ & 0 & -- & -- & 2,000 & 2,000 & 105,000 & $\begin{array}{l}\text { Assumed greater areal recharge rate in Leaf } \\
\text { River area; includes only net areal recharge and } \\
\text { discharge to pumping wells of 2,000 Mgal/yr in } \\
1998 \text {. }\end{array}$ \\
\hline \multirow[t]{5}{*}{$\begin{array}{l}\text { Pineland Sands } \\
\text { surficial aquifer } \\
\text { (Helgesen, 1977) }\end{array}$} & $\begin{array}{l}\text { hydrograph } \\
\text { analysis }\end{array}$ & 0 & -- & -- & -- & 0 & 99,000 & Includes only recharge sources. \\
\hline & $\begin{array}{l}\text { steady-state } \\
\text { simulation }\end{array}$ & 5,000 & 65,000 & -- & 0 & 70,000 & 0 & $\begin{array}{l}\text { Steady-state simulation; excludes withdrawals } \\
\text { by wells. }\end{array}$ \\
\hline & $\begin{array}{l}\text { steady-state } \\
\text { simulation }\end{array}$ & 5,000 & 65,000 & -- & 800 & 70,800 & -800 & $\begin{array}{l}\text { Minor loss of aquifer storage; minimal recharge } \\
\text { from irrigation; simulated pumping of } 3.3 \mathrm{ft}^{3} / \mathrm{s} \\
(800 \mathrm{Mgal} / \mathrm{yr}) \text {. }\end{array}$ \\
\hline & $\begin{array}{l}\text { steady-state } \\
\text { simulation }\end{array}$ & 5,000 & 65,000 & -- & 14,000 & 84,000 & $-14,000$ & $\begin{array}{l}\text { Moderate loss of aquifer storage and surface } \\
\text { water; minimal recharge from irrigation; } \\
\text { simulated pumping of } 60 \mathrm{ft}^{3} / \mathrm{s}(14,000 \mathrm{Mgal} / \mathrm{yr}) \text {. }\end{array}$ \\
\hline & $\begin{array}{l}\text { steady-state } \\
\text { simulation }\end{array}$ & 5,000 & 65,000 & -- & 28,000 & 98,000 & $-28,000$ & $\begin{array}{l}\text { Moderate loss of aquifer storage and surface } \\
\text { water; minimal recharge from irrigation; } \\
\text { simulated pumping of } 120 \mathrm{ft}^{3} / \mathrm{s} \\
(28,000 \mathrm{Mgal} / \mathrm{yr}) \text {. }\end{array}$ \\
\hline $\begin{array}{l}\text { Straight River } \\
\text { Basin area } \\
\text { (Pineland Sands } \\
\text { surficial aquifer- } \\
\text { Stark and others, } \\
\text { 1994) }\end{array}$ & $\begin{array}{l}\text { numerical } \\
\text { (summer) } \\
\text { steady-state } \\
\text { simulation }\end{array}$ & -- & 15,000 & -- & 6,700 & 21,700 & 300 & $\begin{array}{l}\text { Greater rate of areal recharge per area } \\
\text { characteristics; steady-state system; simulated } \\
\text { pumping of } 28.4 \mathrm{ft}^{3} / \mathrm{s}(6,700 \mathrm{Mgal} / \mathrm{yr}) \text {. }\end{array}$ \\
\hline
\end{tabular}


Table A3. Comprehensive list of estimated water budgets for selected surficial aquifers in Red River of the North Basin, Minnesota.-Continued

[Mgal, millions of gallons; $\mathrm{mi}^{2}$, square miles; in/yr, inches per year; Mgal/yr, millions of gallons per year; --, data not available; $\mathrm{ft}^{3} / \mathrm{s}$, cubic feet per second]

\begin{tabular}{|c|c|c|c|c|c|c|c|c|}
\hline \multirow[b]{2}{*}{$\begin{array}{l}\text { Aquifer name } \\
\text { (reference) }\end{array}$} & \multirow[b]{2}{*}{$\begin{array}{l}\text { Method of } \\
\text { determination }\end{array}$} & \multicolumn{4}{|c|}{ Losses of water from aquifer } & \multirow{2}{*}{$\begin{array}{l}\text { Total losses } \\
\text { (outflows) of } \\
\text { water from } \\
\text { aquifer } \\
\text { (Mgal/yr) }\end{array}$} & \multirow{2}{*}{$\begin{array}{l}\text { Differences } \\
\text { between } \\
\text { sources and } \\
\text { losses of water } \\
\text { in aquifer } \\
\text { (Mgal/yr) }\end{array}$} & \multirow[b]{2}{*}{ Explanation of estimated water budget } \\
\hline & & $\begin{array}{l}\text { Evapotrans- } \\
\text { piration } \\
\text { (Mgal/yr) }\end{array}$ & $\begin{array}{c}\text { Flow to surface } \\
\text { water }^{4} \\
\text { (Mgal/yr) }\end{array}$ & $\begin{array}{c}\text { Flow across } \\
\text { boundaries } 4 \\
\text { (Mgal/yr) }\end{array}$ & $\begin{array}{c}\text { Withdrawals } \\
\text { by pumping } \\
\text { wells }{ }^{2} \\
\text { (Mgal/yr) }\end{array}$ & & & \\
\hline $\begin{array}{l}\text { Bemidji-Bagley } \\
\text { surficial aquifer } \\
\text { (Stark and others, } \\
\text { 1991) }\end{array}$ & $\begin{array}{l}\text { hydrograph } \\
\text { analysis }\end{array}$ & 0 & -- & -- & -- & 0 & 44,000 & Sources include areal recharge; losses unknown. \\
\hline $\begin{array}{l}\text { Bemidji-Bagley } \\
\text { regional system } \\
\text { (confined / } \\
\text { unconfined } \\
\text { aquifers-Stark and } \\
\text { others, 1991) }\end{array}$ & $\begin{array}{l}\text { numerical } \\
\text { (regional) } \\
\text { steady-state } \\
\text { simulation }\end{array}$ & 0 & $6,100,000$ & -- & 47,000 & $6,147,000$ & 63,000 & $\begin{array}{l}\text { Confined and unconfined aquifer systems; } \\
\text { excludes flow to/from aquifers/confined units. }\end{array}$ \\
\hline
\end{tabular}

${ }^{1}$ Aquifer storage from published information or estimated from saturated thickness data and aquifer extent (see table 1).

${ }^{2}$ Values reported directly from cited reference; except where withdrawals by wells in 2003 are reported by the Minnesota Department of Natural Resources.

${ }^{3}$ Mean annual precipitation data from 2003 for county/area from www.climate.umn.edu.

${ }^{4}$ Values calculated (converted to similar units) from data reported in cited reference. 